UNITED STATES DEPARTMENT OF THE INTERIOR

GEOLOGICAL SURVEY

\title{
SUMMARY OF U.S. GEOLOGICAL SURVEY INVESTIGATIONS AND HYDROLOGIC CONDITIONS IN THE SOUTHWEST FLORIDA WATER MANAGEMENT DISTRICT FOR 1977
}

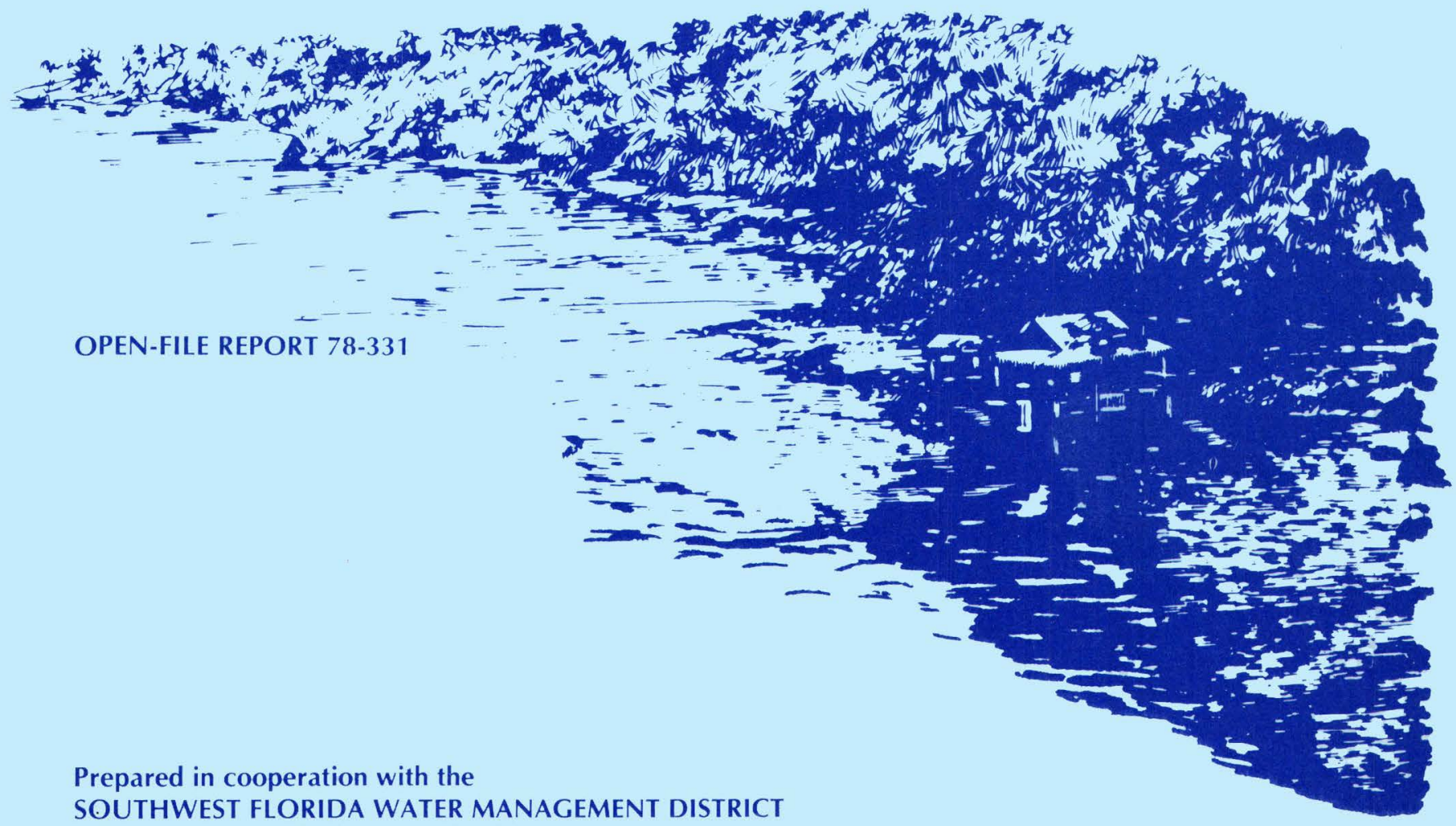

SOUTHWEST FLORIDA WATER MANAGEMENT DISTRICT

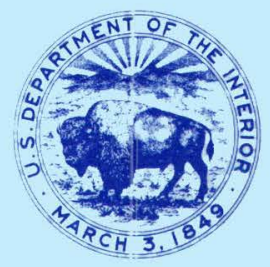




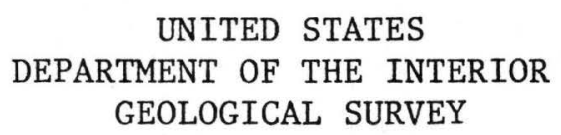

SUMMARY OF U.S. GEOLOGICAL SURVEY INVESTIGATIONS AND

HYDROLOGIC CONDITIONS IN THE SOUTHWEST FLORIDA WATER

MANAGEMENT DISTRICT FOR 1977

By A. Buono, K. W. Causseaux, and J. E. Moore

Open-File Report 78-331

Prepared in cooperation with the

SOUTHWEST FLORIDA WATER MANAGEMENT DISTRICT

Ta1lahassee, Florida

May 1978 
UNITED STATES DEPARTMENT OF THE INTERIOR

CECIL D. ANDRUS, Secretary

GEOLOGICAL SURVEY

H. William Menard, Director

For additional information write to:

U.S. Geological Survey

325 John Knox Road, Suite F-240

Ta1lahassee, Florida 32303 


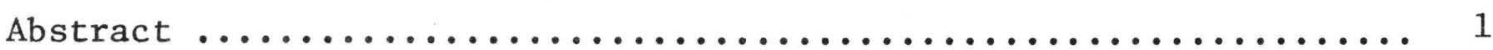

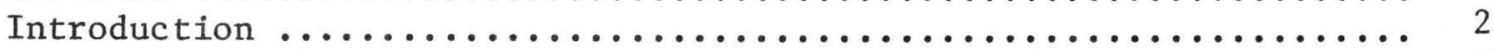

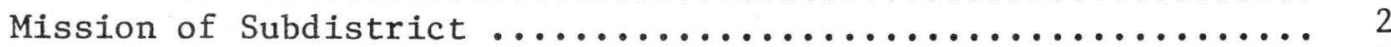

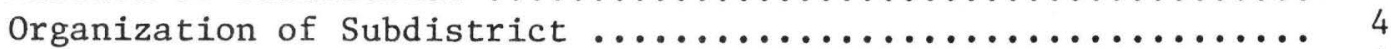

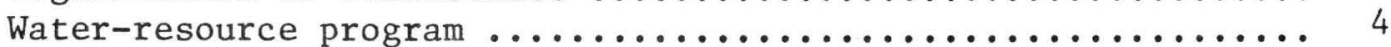

Summary of water-resources investigations ................ 7

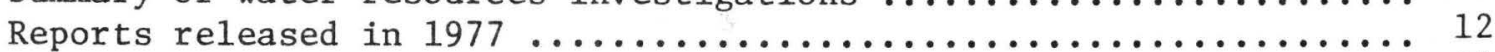

Reports released by the U.S. Geological Survey, 1933-77 ......... 21

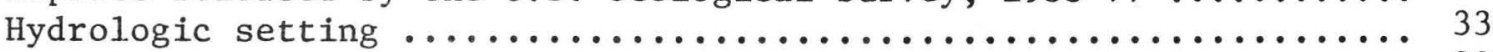

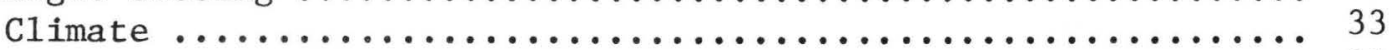

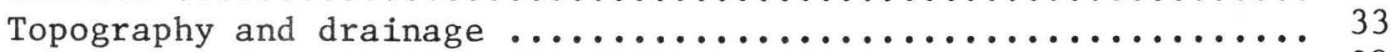

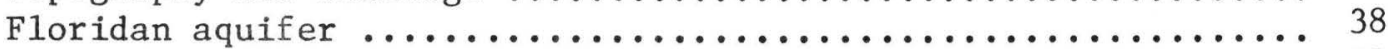

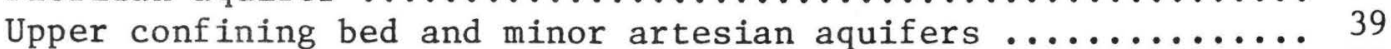

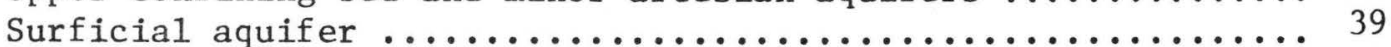

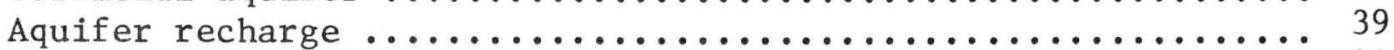

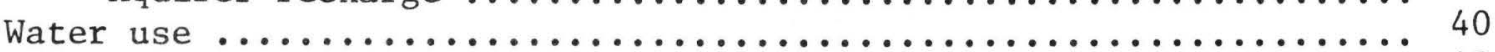

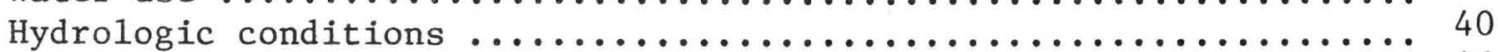

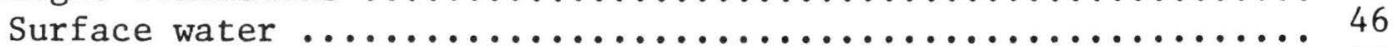

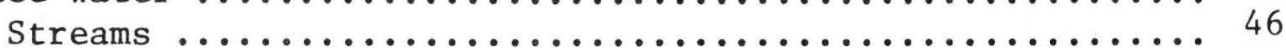

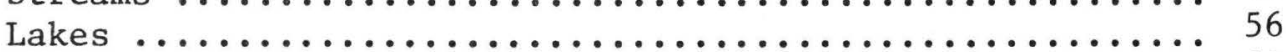

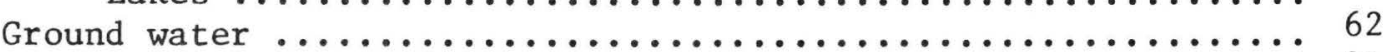

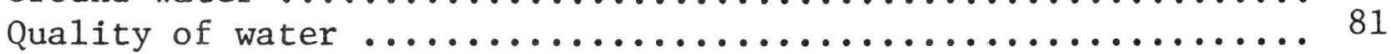

\section{ILLUSTRATIONS}

Figure 1. Map showing location of Southwest Florida Subdistrict showing the boundaries of the Southwest Florida Water Management District's Water Management Basins ........

2. Organization chart for the Subdistrict ..............

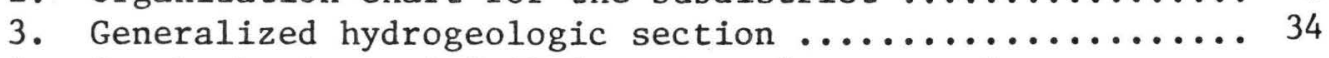

4. Graph showing rainfall departure from normal at

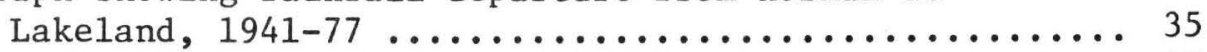

5. Map showing major drainage basins in southwest Florida . 37

6. Map showing surface-water use in southwest Florida, 1975

7. Map showing ground-water use in southwest Florida, 1975

8. Map showing location of the major municipal well fields

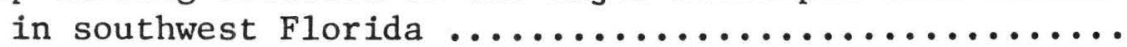

9. Rainfall map of southwest Florida, 1956-75 .......... 10. Rainfall map of southwest Florida, July 1976-June 1977 . 11. Map showing U.S. Geological Survey streamflow network

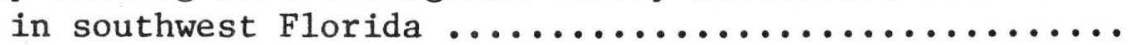

12. Map showing location of streamflow stations for which hydrographs are presented in this report .......... 
Figure 13. Hydrographs of streamflow for the Peace River at

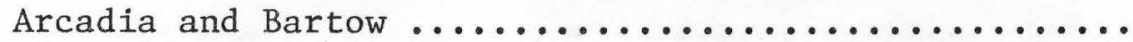

14. Hydrographs of streamflow for the Withlacoochee River

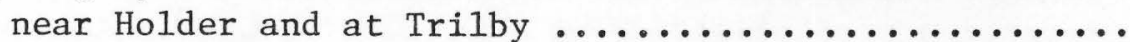

15. Hydrographs of streamflow for the Myakka River near Sarasota and the Little Manatee River near Wimauma ...

16. Hydrographs of streamflow for the Alafia River at Lithia and the Hillsborough River near Zephyrhills ........

17. Hydrographs of streamflow for the Anclote River near Elfers and Brooker Creek near Tarpon Springs ........

18. Hydrograph of streamflow for the Pithlachascotee River

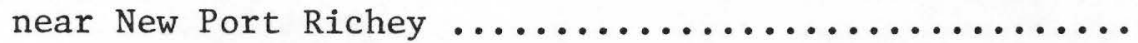

19. Map showing U.S. Geological Survey lake-stage network

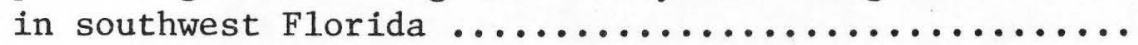

20. Map showing location of lake stations for which hydro-

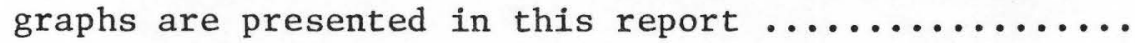

21. Hydrographs of lake stage for Lake Hamilton near Lake Hamilton and Lake Howard at Winter Haven ..........

22. Hydrographs of lake stage for Lake Otis at Winter Haven and Crooked Lake near Babson Park .............. 60

23. Hydrographs of lake stage for Lake Thonotosassa at Thonotosassa and Lake Carroll near Sulphur Springs ...

24. Hydrographs of lake stage for Lake Magdalene near Lutz

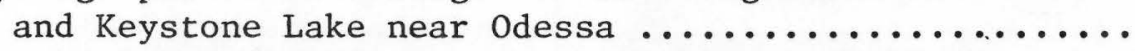

25. Hydrographs of lake stage for Lake Tsala-Apopka at Inverness and Lake Panasoffkee near Lake Panasoffkee.

26. Map showing U.S. Geological Survey ground-water network

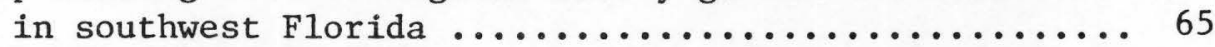

27. Map showing the potentiometric surface of the Floridan

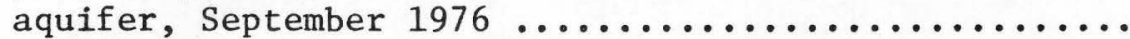

28. Map showing the potentiometric surface of the Floridan

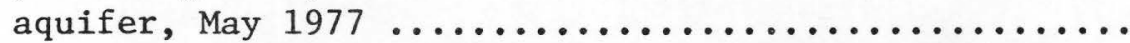

29. Map showing the potentiometric surface of the Floridan

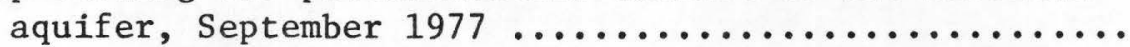

30. Maps showing the potentiometric surface of the Floridan aquifer in selected well fields for May 1977 .......

31. Maps showing the water table in the surficial aquifer

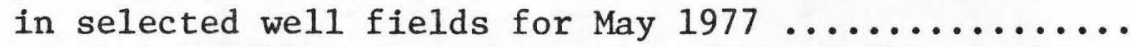

32. Maps showing the potentiometric surface of the Floridan aquifer in selected well fields for September 1977 ...

33. Maps showing the water table in the surficial aquifer in selected well fields for September 1977 .........

34. Map showing the location of Floridan aquifer wells for which hydrographs are presented in this report .......

35. Hydrographs for Mulberry well at Mulberry and Maddox

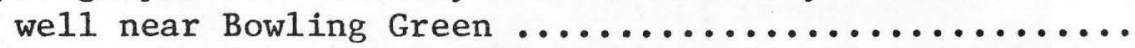

36. Hydrographs for Hollingsworth deep well near Pine Level, Sarasota we11 9 near Sarasota, and Verna deep we11 1A

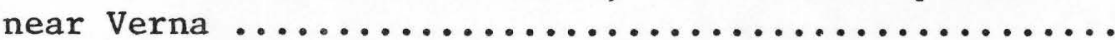


Figure 37. Hydrographs for Council deep well near Ruskin, Tampa we11 15 near Dover, and Hillsborough deep well 13

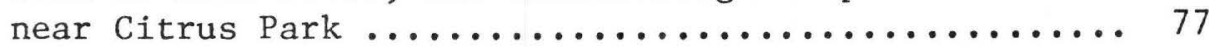

38. Hydrographs for Pasco well 13 near Drexe1, Cypress Creek we11 3 near Darby, and Eldridge-Wilde well 11

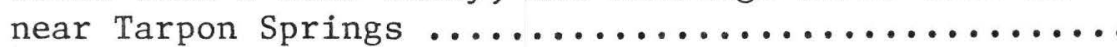

39. Hydrographs for Pinellas well 665 near Clearwater, Weeki Wachee well near Weeki Wachee, and North

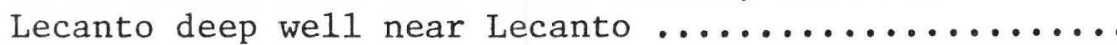

40. Map showing U.S. Geological Survey surface-water quality of water network in southwest Florida .......

41. Map showing U.S. Geological Survey ground-water quality of water network in southwest Florida .......

42. Map showing U.S. Geological Survey chloride monitor

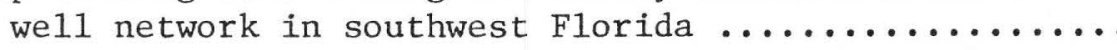

43. Graph of chloride concentration for New Port Richey well near New Port Richey and Coachman well near

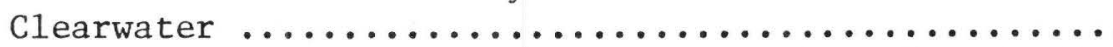

44. Graph of chloride concentration for Presbyterian Youth Camp well near Weeki Wachee and Homosassa well 3 near

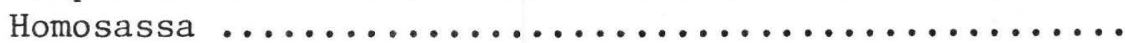

45. Graph of chloride concentration for SWFWMD well S-160 at Tampa, McMullen Campground we11 near Riverview,

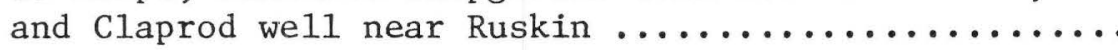

\section{CONVERSION FACTORS}

For use of those readers who may prefer to use metric units rather than U.S. customary units, the conversion factors for the terms used in this report are listed below:

U.S. customary units

inch (in)

foot (ft)

mile (mi)

gallon (gal)

gallons per minute (ga1/min)

cubic foot per second $\left(\mathrm{ft}^{3} / \mathrm{s}\right)$

degrees Fahrenheit $\left({ }^{\circ} \mathrm{F}\right)$
Multiply by

25.40

0.3048

1. 609

3.785

$3.785 \times 10^{-3}$

0.6308

0.02832

$\left({ }^{\circ} \mathrm{F}-32\right) \times 0.556$
To obtain metric units

millimeter (mm)

meter (m)

kilometer $(\mathrm{km})$

liter (L)

cubic meter $\left(\mathrm{m}^{3}\right)$

liters per second (L/S)

cubic meter ${ }_{3}$ per second $\left(\mathrm{m}^{3} / \mathrm{s}\right)$

degrees Celsius

(centigrade) $\left({ }^{\circ} \mathrm{C}\right)$ 


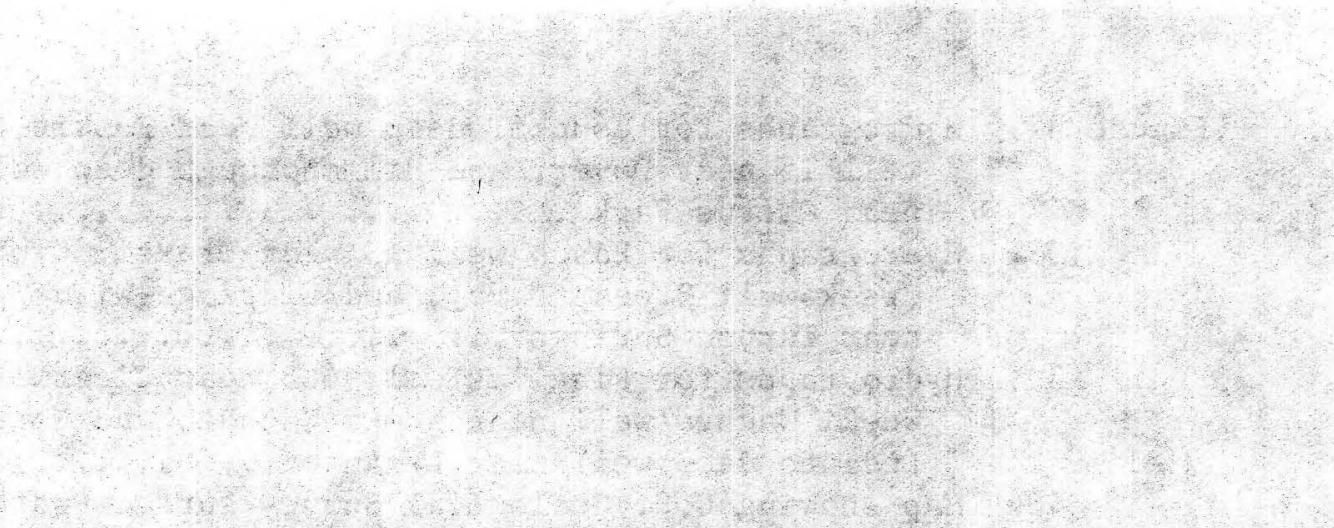
(1) (1) n?

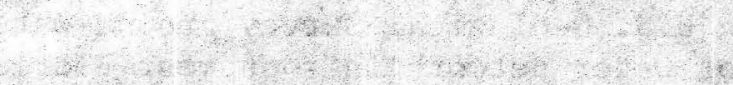

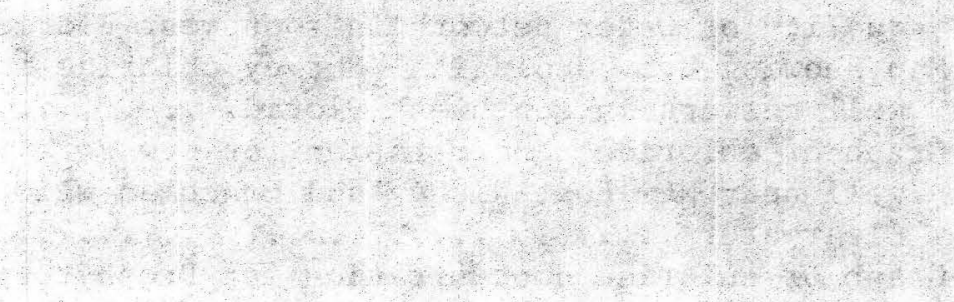

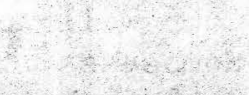

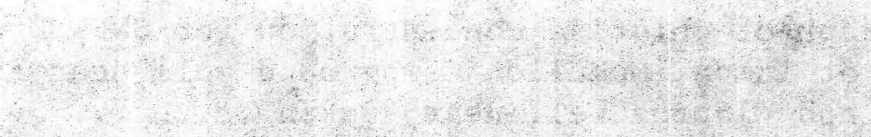

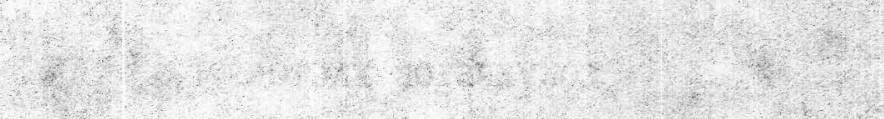

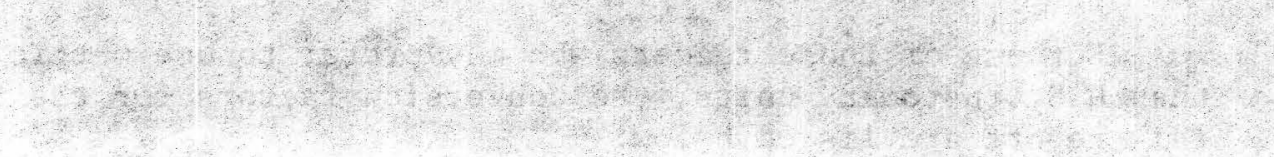

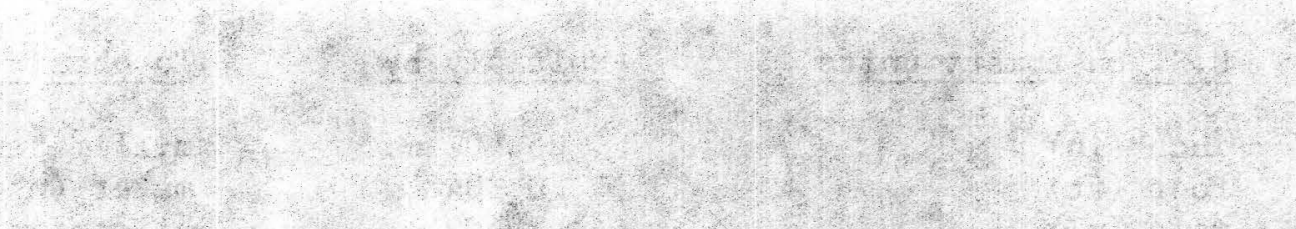

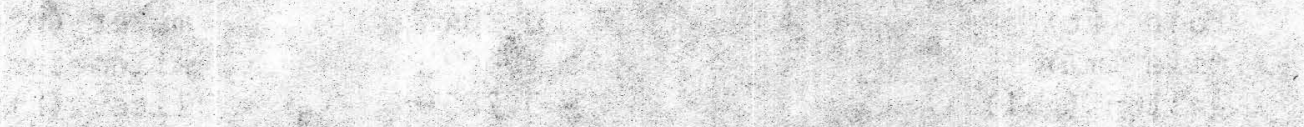

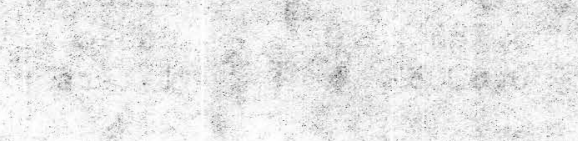

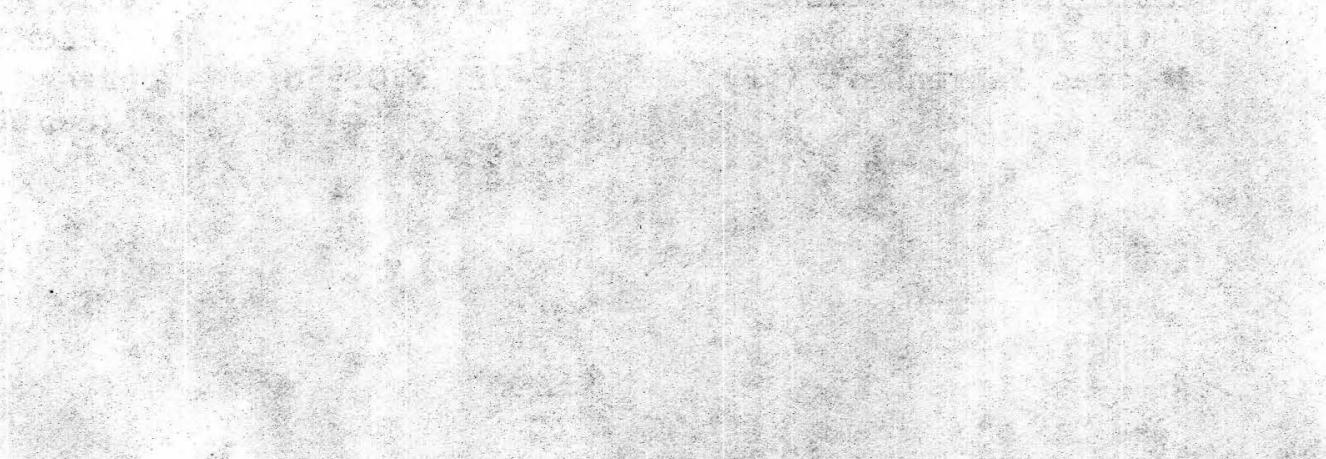




\title{
SUMMARY OF U.S. GEOLOGICAL SURVEY INVESTIGATIONS AND HYDROLOGIC CONDITIONS IN THE SOUTHWEST FLORIDA WATER MANAGEMENT DISTRICT FOR 1977
}

By

A. Buono, K. W. Causseaux, and J. E. Moore

\begin{abstract}
This report summarizes the activities of the Southwest Florida Subdistrict Office of the U.S. Geological Survey, Water Resources Division for fiscal year 1977. The organization and mission of the subdistrict office are described. The cooperative program for fiscal year 1977 included 41 interpretive investigations. Abstracts of twenty reports released by the subdistrict during 1977 and an extensive bibliography of reports released from 1933 to 1977 are included. The hydrologic setting of southwest Florida is outlined followed by discussions of surface-water, ground-water, and quality-of-water conditions. Hydrologic conditions in southwest Florida in 1977 are shown by the presentation of hydrographs from selected surface-water, ground-water, and lake-stage data collection sites.
\end{abstract}




\section{INTRODUCTION}

This report describes the hydrologic conditions and studies in southwest Florida being made by the U.S. Geological Survey. The report is a ready reference for all professionals and laymen who are interested in the water resources of the area. The preparation of this report was funded as a part of the cooperative program with the Southwest Florida Water Management District.

The report contains a description of the organization of the U.S. Geological Survey subdistrict office at Tampa, a description of active water-resources investigations, a summary of water use, and a discussion of hydrologic conditions. In addition, the report contains a list of reports prepared by the U.S. Geological Survey in southwest Florida.

\section{Mission of Subdistrict}

The Southwest Florida Subdistrict Office, located in Tampa, is a part of the Florida District which is headquartered in Tallahassee. Other major field offices are located in Miami, Orlando, Jacksonville and Tallahassee. The Southwest Florida Subdistrict office collect analyzes, and interprets water-resource information in a $10,000 \mathrm{mi}^{2}$ area (10 counties and part of 6 others) in southwestern Florida (fig. 1), an area whose boundaries coincide with those of the Southwest Florida Water Management District except for the Green Swamp and Withlacoochee basins. Investigations are made in cooperation with Federal, State, County and local agencies.

The mission of the subdistrict is as follows:

1. Collecting hydrologic data needed for the continuing determination and evaluation of the quantity, quality, and use of water resources.

2. Conducting analytical and interpretive water-resources appraisals describing the occurrence and availability of water, and the physical, chemical, and biological characteristics of surface and ground water.

3. Conducting investigations using modeling techniques as tools to further the understanding of hydrologic systems and to quantitatively predict the response of these systems to stress, either natural or manmade.

4. Disseminating water data and results of investigations and research through reports, maps, computerized information services, and other forms of public release.

5. Providing scientific and technical assistance in hydrology and related fields to other Federal, State, and local agencies. 


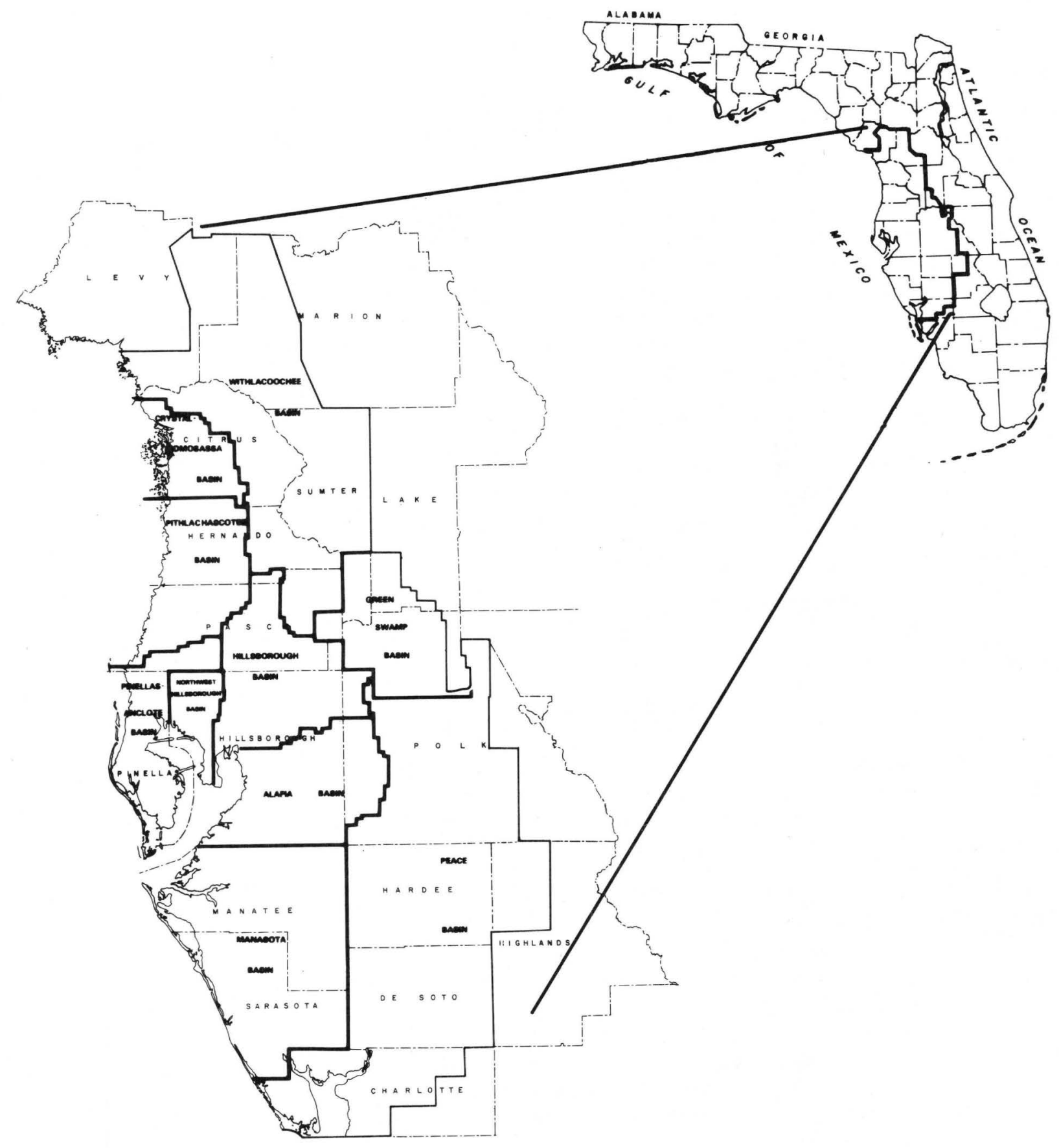

$10 \quad 0 \quad 10 \quad 20 \quad 30 \quad 40 \quad 50$ MILES

Figure 1. Location of Southwest Florida Subdistrict showing the boundaries of the Southwest Florida Water Management District's Water Management Basins. 


\section{Organization of Subdistrict}

The Southwest Florida Subdistrict consists of five operating sections (fig. 2) and two support sections. Responsibility for each project is assigned to a project chief. In October 1977, the subdistrict staff consisted of 65 employees, of which 62 are assigned to the subdistrict office and 3 to a field office in Sarasota. The staff is assisted by research centers, laboratories, technical consultants, and training schools maintained by the Water Resources Division of the U.S. Geological Survey. The five operating sections of the subdistrict are:

1. Hydrologic Records

2. Water Quality

3. Surface Water Hydrology

4. Hydrogeology

5. Hydrologic Simulation and Technical Support.

The two support sections are:

1. Administrative

2. Reports.

\section{Water-Resource Program}

The subdistrict program is diversified and encompasses all aspects of water information needs in the area. The cooperative program for fiscal year 1977 included 41 interpretive investigations. Hydrologic data were obtained at more than 1,000 sites.

The eighteen Federal, State, County, City and local agencies that contributed funds for investigations and data collection are as follows:

U.S. Army Corps of Engineers

U.S. Department of Housing and Urban Development

U.S. Geologica1 Survey

Florida Department of Environmental Regulation

Florida Department of Transportation

Florida Department of Pollution Control

Southwest Florida Water Management District

Charlotte County

Hillsborough County

Manatee County

Sarasota County

Pinellas County

Clearwater

St. Petersburg

Tampa

Sarasota

Englewood Water District

Winter Haven Boat Course District 


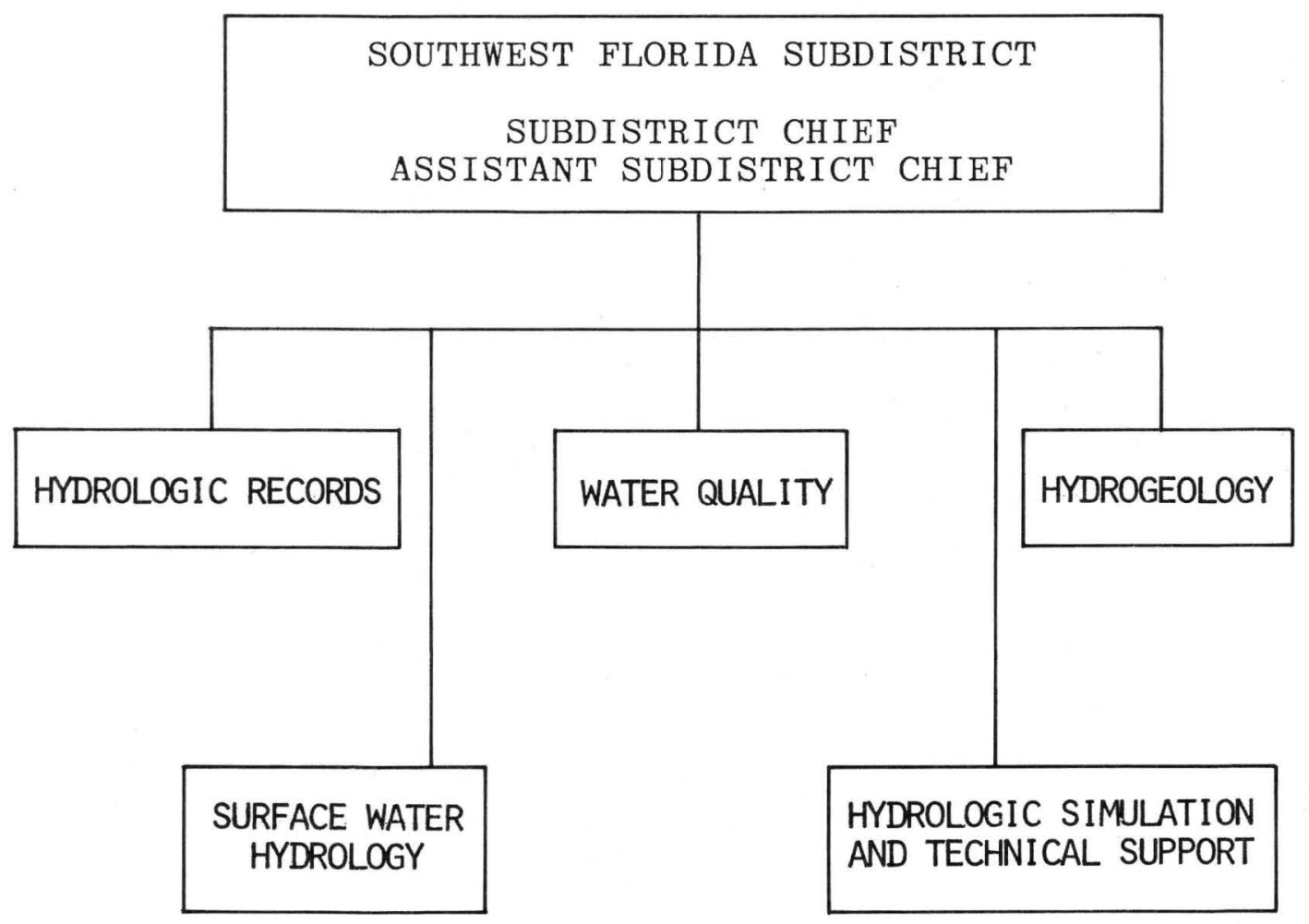

Figure 2. Organization chart for the Subdistrict 
Water-resources investigations undertaken by the U.S. Geological Survey deal with the following types of questions:

1. What are the effects of municipal well field development?

2. What is the hydrologic relation between ground water, lakes, and wetlands?

3. What areas are suitable for artificial recharge?

4. What areas are affected by inland movement of saltwater?

5. What areas are most suitable for subsurface injection?

6. What is the quality of ground water in southwest Florida?

7. What is the effect of dredging on Tampa Bay?

8. What is the impact of irrigation and phosphate development on ground water?

9. How much land is inundated at times of floods?

10. How does urbanization affect runoff?

11. How much does pumping affect ground water and lake levels?

12. Is sufficient ground water available to meet present and projected needs?

13. How can streamflow be regulated where water use is intense?

Requests for information on the U.S. Geological Survey's investigations of the water resources in southwest Florida should be directed to:

District Chief

U.S. Geological Survey

Suite F-240

325 John Knox Road

Tallahassee, Florida 32303

Telephone: (904) 386-1118

Subdistrict Chief

Southwest Florida Subdistrict

U.S. Geological Survey

Tampa Commerce Ma11

4710 Eisenhower B1vd., B-5

Tampa, Florida 33614

Telephone: (813) 228-2124

Subdistrict Chief

Northeast Florida Subdistrict

U.S. Geological Survey

Suite 216, Federal Building

80 North Hughey Avenue

Orlando, Florida 32808

Telephone: (305) 420-6191 
Current and proposed investigations in Southwest Florida Subdistrict office are divided into the eleven categories listed below. The investigations range from basic descriptive water-availability studies to sophisticated cause and effect studies.

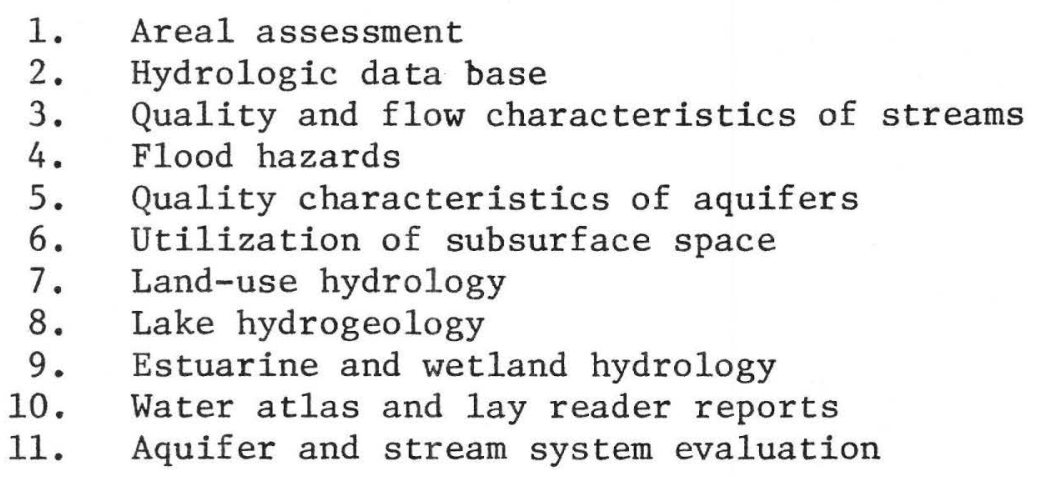

\section{Area1 Assessment}

Areal hydrologic investigations are needed to provide basic hydrogeologic information for more sophisticated studies and to describe the water-supply characteristics of major aquifers and river basins on a regional basis.

\begin{tabular}{|c|c|c|c|c|c|c|}
\hline 1. AREAL & ASSESSMENT & 1977 & 1978 & 1979 & 1980 & $1981-$ \\
\hline FL-158 & Hydrology of Englewood & & & & & \\
\hline FL-191 & We11 field maps & & & & & \\
\hline FL-210 & Well field evaluation & & & & & \\
\hline FL-215 & Water supply, Green Swamp area & & & & & \\
\hline FL-227 & Hydrology of Sarasota County & & & & & \\
\hline FL-242 & Hydrology of Manatee County & & & & & \\
\hline FL-256 & Potentiometric maps & & & & & \\
\hline FL-257 & Aquifer characteristics & & & & & \\
\hline FL -300 & Water resources of Manasota & & & & & \\
\hline FL-301 & Withlacoochee & & & & & \\
\hline Proposed & Ground water, Pasco County & & & & - & -- \\
\hline Proposed & $\begin{array}{c}\text { Shallow ground water, } \\
\text { Pinellas County }\end{array}$ & & & & - & -- \\
\hline
\end{tabular}




\section{Hydrologic Data Base}

Hydrologic data provide background information on flow characteristics of rivers, changes in the amount of ground-water storage, change in water use, and quality of ground and surface water. These data are needed for the appraisal, protection, and management of the water resources. The effort consists of maintaining surface- and ground-water data networks, and the collection and assembly of hydrologic records such as water levels, geologic information, water use, and miscellaneous flow measurements.

\begin{tabular}{|c|c|c|c|c|c|c|}
\hline 2. HYDRO & LOGIC DATA BASE & 1977 & 1978 & 1979 & 1980 & 1981 \\
\hline FL-001 & Surface-water records & & & & & \\
\hline FL-002 & Ground-water records & & & & & \\
\hline FL-003 & Quality-water records & & & & & \\
\hline FL-007 & Water-use inventory & & & & & \\
\hline FL-179 & Verna well field & & & & & \\
\hline FL-208 & $\begin{array}{l}\text { Technical assistance - } \\
\text { ground water }\end{array}$ & & & & & \\
\hline FL-232 & $\begin{array}{c}\text { Technical assistance - } \\
\text { Hillsborough County }\end{array}$ & & & & & \\
\hline FL-263 & Remote data acquisition & & & & & \\
\hline FL-280 & Annual report & & & & & \\
\hline FL-281 & $\begin{array}{l}\text { Technical assistance - } \\
\text { Pinellas County }\end{array}$ & & & & & \\
\hline
\end{tabular}




\section{Quality and Flow Characteristics of Streams}

Investigations of water quality and flow characteristics of streams define existing conditions and predict changes in quality and flow characteristics under various plans of basin development. All activities pertaining to this category of investigation have been completed but several proposals are currently being reviewed as future studies.

\section{QUALITY AND FLOW CHARACTERISTİCS OF STREAMS}

\section{$\begin{array}{lllll}1977 & 1978 & 1979 & 1980 & 1981\end{array}$}

Proposed Low-flow studies

Proposed Braden River water supply

Proposed Waste load assimilation

\section{Flood Hazards}

Flood investigations are made to define the frequency, duration, and magnitude of floods. Information on the probability and extent of future floods is needed to reduce flood losses and to protect life and property. This is particularly important in areas of increased urbanization.

\begin{tabular}{|c|c|c|c|c|c|c|}
\hline 4. FLOOD & HAZARDS & 1977 & 1978 & 1979 & 1980 & 1981 \\
\hline FL-006 & HUD flood studies & & & & -- & -- \\
\hline FL-267 & Watershed modeling & & & & & \\
\hline FL -277 & Regional flood frequency & & & & & \\
\hline Proposed & $\begin{array}{l}\text { Flood frequency in tidal } \\
\text { streams }\end{array}$ & & & & - & -- \\
\hline
\end{tabular}




\section{Quality Characteristics of Aquifers}

Water-quality investigation of aquifers are made to define areas of contamination, relation of fresh ground water and surface water, and to predict changes in water quality.

\section{QUALITY CHARACTERISTICS OF AQUIFERS $\quad \begin{array}{llllll}1977 & 1978 & 1979 & 1980 & 1981\end{array}$}

FL-285 Saltwater encroachment

FL-285a Resistivity study

FL-302 Radionuclides in ground water

\section{Utilization of Subsurface Space}

Investigations are made of subsurface space to evaluate effect of injecting treated waste into wells tapping saline aquifers, to determine means of artificially recharging aquifers, and evaluate the potential movement of stored fresh or waste waters.

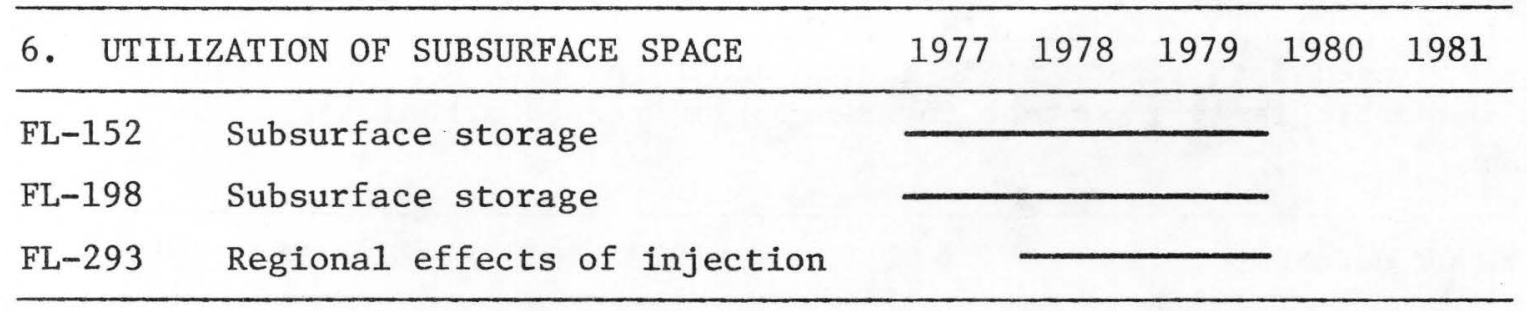

\section{Land-Use Hydrology}

Land-use hydrologic investigations provide information needed for land-use planning and zoning, water-resources management, and evaluation of the effects of man-made alterations to the environment.

\begin{tabular}{llllll}
\hline 7. LAND-USE HYDROLOGY & 1977 & 1978 & 1979 & 1980 & 1981 \\
\hline FL-107 & $\begin{array}{c}\text { Landfill sites, Hillsborough } \\
\text { County }\end{array}$ & & & & \\
FL-219 & Urban hydrology & & & & \\
\hline
\end{tabular}




\section{Lake Hydrology}

Lake hydrology investigations provide an understanding of the role of lakes in the hydrologic system, define possible cause of changes in lake water quality and lake levels.

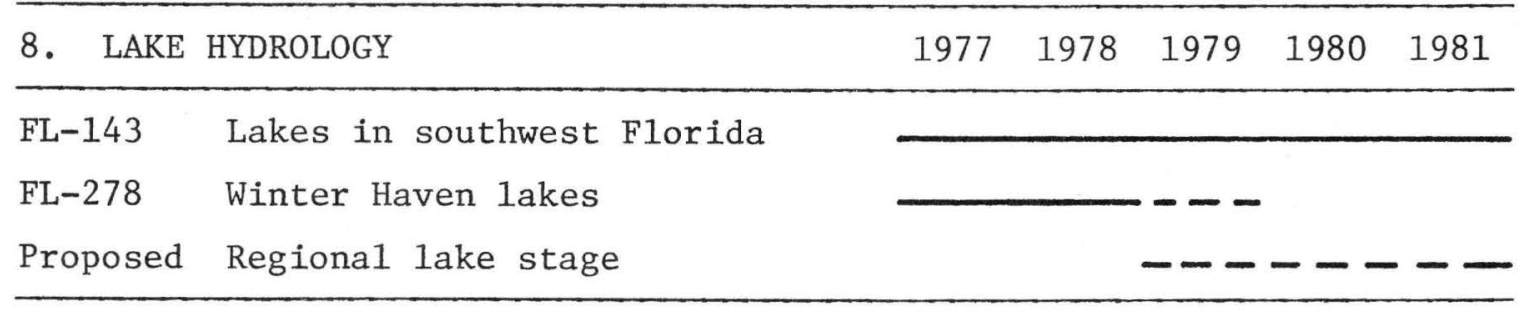

\section{Estuarine and Wetland Hydrology}

Estuarine investigations are made to determine hydrology and waterquality conditions and to predict changes due to proposed development.

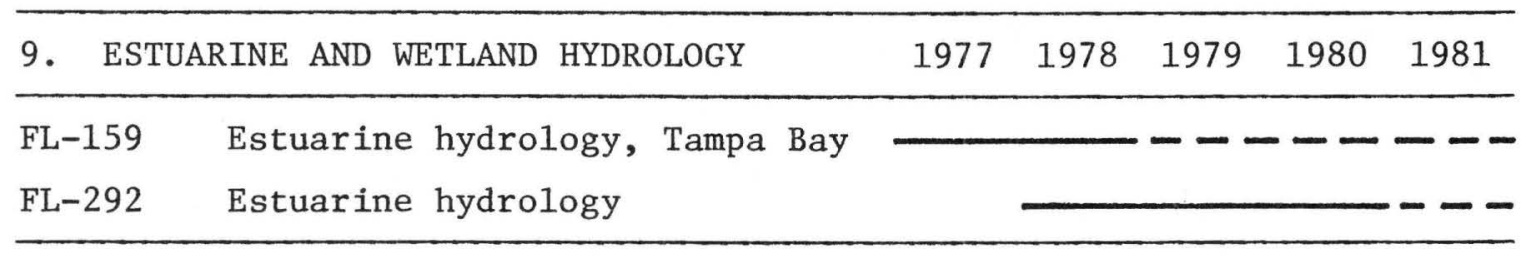

10. Water Atlas and Lay Reader Reports

Atlases and brochures will be prepared describing hydrology problems and principals to provide the public with a better understanding of the water resources of southwest Florida.

10. WATER ATLAS AND LAY READER REPORTS

$1977 \quad 1978 \quad 1979 \quad 1980 \quad 1981$

$\begin{array}{llr}\text { Proposed } & \text { Planning report } & \\ \text { Proposed } & \text { District map atlas } & \\ \text { Proposed } & \text { Lay reader report }\end{array}$




\title{
11. Aquifer and Stream System Evaluation
}

Aquifer and stream system models investigations are made to predict the effects of proposed industrial, municipal or agricultural developments.

11. AQUIFER AND STREAM SYSTEM
EVALUATION

\begin{tabular}{ll}
\hline FL-264 & $\begin{array}{l}\text { Effect of ground-water } \\
\text { development }\end{array}$ \\
FL-265 & $\begin{array}{l}\text { Water supply, Hillsborough } \\
\text { River }\end{array}$ \\
\hline
\end{tabular}

Active $\quad-\cdots--$ Proposed

REPORTS RELEASED IN 1977

A total of 20 reports were released by the Southwest Florida Subdistrict in 1977. These reports covered various hydrologic and hydrogeologic problems in southwest Florida and Florida. This section contains a detailed description of each report.

Copies of reports listed in sections of this report entitled, "Reports Released in 1977," and "Reports Released by the U.S. Geological Survey, 1933-77," are available for inspection at the U.S. Geological Survey offices in Tampa, Tallahassee, Miami, and Orlando; at the U.S. Geological Survey Library in Reston, Virginia; at libraries of the State University System of Florida; and the Southwest Florida Water Management District, Office of Communications and Information, 5060 U.S. Highway 41 South, Brooksville, Florida 33512. For information about availability of reports contact the U.S. Geological Survey, 325 John Knox Road, F-240, Tallahassee, Florida 32303.

For annual bulletins, Information Circulars, Map Series, and Reports of Investigations published by the Florida Bureau of Geology, contact the:

\author{
Bureau of Geology \\ Florida Department of Natural Resources \\ 903 West Tennessee Street \\ Tallahassee, Florida 32304
}

Florida Bureau of Geology publications are available for inspection at many public libxaries throughout the State. 
Descriptions of reports released in 1977 follow:

Hickey, J. J., 1977, Hydrogeologic data for the McKay Creek subsurface waste-injection site, Pinellas County, Florida: U.S. Geol. Survey open-file rept. 77-802.

Abstract. - Lithologic, hydraulic, geophysical and water-quality data collected at the McKay Creek test site are reported. Data were collected to determine the possibility of subsurface injection of waste treatment plant effluent into a saline water zone. One exploratory hole, one test injection well, and eight observation wells were drilled.

The lithology of the upper 100 feet is predominantly clay. From 100 to 1,750 feet below land surface, limestone and dolomite predominate. Gypsum is present 1,210 feet below land surface.

Laboratory analyses of cores taken during drilling are given for vertical intrinsic permeability, porosity, interval transit time and compressibility.

Hutchinson, C. B., 1977, Appraisal of shallow ground-water resources and management alternatives in the upper Peace and eastern Alafia River basins, Florida: U.S. Geol. Survey Water-Resources Inv. 77-124.

Abstract. - The shallow aquifer system underlying the 1,250-square-mile upper Peace and eastern Alafia River basins is a relatively untapped source of supply. The shallow aquifer system ranges between 50 and 300 feet thick and is composed of a surficial sand unit underlain by a limestone unit. Sand and clay confining beds separate the shallow aquifer system from the highly productive, extensively developed deep aquifer system. The hydrologic budget of the area indicates that annual leakage of water from the shallow to the deep aquifer system is 2.6 inches while annual pumpage from the deep aquifer system averages 5.5 inches.

Management alternatives to be considered for efficient use of the shallow ground-water resources include development by withdrawal wells or connector wells for recharge. One solution for a gridded network of wells consists of 540 wells spaced 7,000 feet apart, each producing 453 gallons per minute. The network would derive water necessary to meet current demand by capturing water that normally would have run off or evapotranspired.

Hutchinson, C. B., and Mills, L. R., 1977, Water table in the surficial aquifer and the potentiometric surface of the Floridan aquifer in selected well fields, west-central Florida, May 1976: U.S. Geol. Survey open-file rept. 77-257.

Abstract. - - The coastal parts of Fasco, Pinellas and Hillsborough Counties are undergoing extensive urban development. The Floridan aquifer is the area's principal water supply. Potentiometric and water-table maps were prepared in order to determine the effect of ground-water withdrawals in selected well fields in west-central Florida. Water levels of 5 to 10 feet below mean sea level in three of nine producing well fields indicate critical water shortages during the annual low water-level period in March, April and May. 
Hutchinson, C. B., and Stewart, J. W., 1977, Hydrology of Toytown Landfill, St. Petersburg, Florida: U.S. Geol. Survey Water-Resources Inv. $77-78$.

Abstract. - The 250-acre Toytown landfill site is in a poorly-drained area in coastal Pinellas county. The average altitude of land surface at the landfill is less than 10 feet. About 1,000 tons of solid waste and about 200,000 gallons of digested sewage sludge are disposed of daily at the landfill. Three geohydrologic units are recognized at the site including: (1) sand and shell deposits that comprise a 23-foot-thick surficial aquifer which unconformably overlies (2) a marl and clay confining bed, 27 feet thick, which grades downward to (3) chert and limestone of the Floridan aquifer. The Floridan aquifer is used as a limited source of water for domestic supply in this area.

The velocity of ground-water flow through the surficial aquifer northeast from the landfill toward old Tampa Bay probably ranges from 1 to 10 feet per year, and downward velocity through the confining bed is about $7.4 \times 10^{-4}$ foot per day. The horizontal and vertical flow velocities indicate that leachate moves slowly downgradient, and that leachate has not yet seeped through the confining bed after 12 years of landfill operation. Untreated surface runofo from the site averages about 15 inches per year, and ground-water outflow averages about 3.3 inches per year.

The water table in the surficial aquifer is elevated at sludge-reservoir and solid-waste disposal sites, and water quality in these areas is poor. Inside the landfill, both surface and ground water have concentrations of dissolved solids of more than 1,000 milligrams per liter and ammonia nitrogen more than 200 milligrams per liter as nitrogen. Sanitary quality of water is also poor: total coliform counts reach 100,000 colonies per 100 milliliters of sample, total organic carbon concentrations are as much as 1,000 milligrams per liter. Contamination by leachate was not detected in wells more than 15 feet beyond the landfill boundary.

Mills, L. R., and Ryder, P. D., 1977, Saltwater intrusion in the Floridan aquifer, coasta1 Citrus and Hernando Counties, Florida, 1975: U.S. Geo1. Survey Water-Resources Inv. 77-100.

Abstract. - - The coastal parts of Citrus and Hernando Counties--particularly Citrus county--are undergoing extensive urban development along U.S. Highway 19. The Floridan aquifer, a thick sequence of limestone and dolomite, is the principal source of water supply for the coastal parts of these two counties. The construction of canals that penetrate the Floridan aquifer, deficient rainfall during 1964-75, and pumping of ground water, have caused saltwater to intrude the aquifer. The purpose of this report is to show the inland extent of that intrusion as of 1975. The report is based on field data collected in 1964, 1973, and 1975. Field data were collected and the report was prepared in cooperation with the Southwest Florida water Management District. 
Reichenbaugh, R. C., 1976, Effects on ground-water quality from irrigating pasture with sewage effluent near Lakeland, Florida: U.S. Geol. Survey Water-Resources Inv. 76-108.

Abstract. - Since 1969 an average of 25,000 gallons per day of domestic secondary-treated effluent has been used to supplement irrigation of 30 acres of grazed pasture north of Lakeland, Florida. Monitor wells were constructed near the effluent-irrigated pasture. The water table in the surficial aquifer under the pasture varied from 1.0 to 3.3 feet below land surface. Total nitrogen was less than 20 percent of the effluent content after percolating 8 feet; no increase in nitrogen was detected 20 feet below the surface, or in downgradient ground water. There was no evidence of phosphorus or carbon contamination of ground water. Low numbers of bacteria (generally coliform) were noted in some samples from nine wells. Four wells sampled contained bacteria of probable fecal origin. Low-rate application of the effluent to the pasture apparently has had little effect on the soil and ground water.

, 1976, A hydrologic description of Keystone Lake near Tampa,

Florida: U.S. Geol. Survey Water-Resources Inv. 76-124.

Abstract. - The terrain around Keystone Lake, a 388-acre lake in northwest Hillsborough County near the Cosme well field is dotted with sinks that promote leakage from the surficial aquifer to the underlying Floridan aquifer. The lake, an integral part of the Brooker Creek channel, receives overland runofo from cypress swamps, pastures, citrus groves, and lakefront residential areas. The lake, a composite of many coalescing sinkholes, is generally 14 to 16 feet deep and has been dredged in places to 23 feet deep. Since 1960, rainfall in the area shows a cumulative negative departure of 86 inches from the long-term average. The mean annual lake stage in 1973 was the lowest on record. Concurrently, municipal pumpage in the cosme well field from the Floridan aquifer peaked in 1961 and again in 1973, and in 1972 the potentiometric surface was the lowest since 1960. Comparisons of the hydrographs of lake stage and the potentiometric surface in the Floridan aquifer with rainfall graphs shows that both correspond closely to seasonal rainfall, resulting in the trend of decreasing seasonal maximum levels in the lake and the aquifer. Keystone Lake water quality is adequate for recreation and propagation of wildlife.

Reichenbaugh, R. C., and Hughes, G. H., 1977, Evaluation of chemical, biological, and physical conditions in the Winter Haven chain of lakes, Florida, March-June 1976: U.S. Geol. Survey Water-Resources Inv. 77-52.

Abstract. - Reconnaissance of water-quality conditions of 14 interconnected navigable lakes, in and around Winter Haven, revealed that in March and May 1976 most were eutrophic, on the basis of high nutrient (nitrogen and phosphorus) concentrations. Lakes Lulu and Shipp were the most enriched; a result of surface runofo from residential, agricultural, and highly urbanized 
areas and many years of municipal and industrial waste effluent input. Phytoplankton counts were greater than a million cells per milliliter in some lakes sampled; algal blooms have occurred, and water clarity was low.

The level of Lake Howard fell to the lowest recorded stage in 31 years during May 1976. The record low was likely due to rainfall deficiency in the study area. Leakage of water through the lake beds to the ground-water system is also possible, but determination of the escaping water volume would require additional study.

Robertson, A. F., 1977, Flood profiles of the Alafia River, west-central Florida, computed by the step-backwater method: U.S. Geo1. Survey Water-Resources Inv. 77-74.

Abstract. -- Flood profiles have been determined for about 42 river miles of the Alafia River and its two principal tributaries, the North Prong Alafia River and the South Prong Alafia River. Flood-peak discharges with recurrence intervals of $2.33,5,10,25,50,100$, and 200 years were determined by graphically averaging the results of regional flood frequency analyses and log-Pearson Type III frequency analyses for two gaging stations in the basin.

Flood heights were calculated at 151 cross sections of the Alafia River and its two principal tributaries utilizing the step-backwater method. These calculated flood heights are judged to be accurate within plus or minus 0.5 foot. Connecting the flood heights between cross sections by straight lines resulted in the flood profiles which can be used in conjunction with topographic maps to delineate the area of flooding.

Robertson, A. F., and Mallory, M. J., 1977, A digital model of the Floridan aquifer, Tampa Bay area, Florida: U.S. Geol. Survey Water-Resources Inv. 77-64.

Abstract. - - West-central Florida has had considerable growth in population with resultant commercial and industrial development in the past two decades. A method to evaluate the effects of proposed ground-water withdrawals on the Floridan aquifer is needed to help insure orderly development of the groundwater resource. A regional ground-water model of the aquifer was constructed for an 875 square mile 12,270 square kilometer) portion of the rapidly developing area north of Tampa Bay.

The digital model was calibrated by comparing observed (May 1974 and May 1975) and computed potentiometric heads. A good comparison was obtained by adjusting leakance and transmissivity. Differences between the computed and measured potentiometric surface were generally less than 3 feet 1.9 meters) with a worst error of 15 feet ( 4.5 meters). The calibrated model may be used as a predictive tool. For example, the model could be used to evaluate the regional effects of increased ground-water withdrawal on the Floridan aquifer.

Calibration of the model resulted in a better understanding of the Floridan aquifer in the area modeled. It was noted that the transmissivity distribution obtained from aquifer pumping tests is adequate, that leakage 
is more variable than pumping tests generally indicate, and that direct connection of rivers and lakes with the Floridan aquifer cannot be assumed for regional modeling.

Ryder, P. D., Laughlin, C. P., and Mills, L. R., 1977, Potentiometric surface of the Floridan aquifer, Southwest Florida Water Management District and adjacent areas, May 1977: U.S. Geol. Survey open-file rept. 77-552.

Abstract. -- A May 1977 potentiometric-surface map of the Southwest Florida water Management District depicts the annual low water-level period. Potentiometric levels declined as much as 30 feet between september 1976 and May 1977 in the citrus and farming sections of southeastern Hillsborough, northwestern Hardee, and northern Manatee Counties. These areas are widely affected by pumpage for irrigation and have the greatest range in water-level fluctuations between the low and high water-level periods. Water-level declines in coastal, northern and southern areas of the Water Management District ranged from 0-15 feet.

Ryder, P. D., and Mills, L. R., 1977, Water table in the surficial aquifer and the potentiometric surface of the Floridan aquifer in selected well fields, west-central Florida, September 1976: U.S. Geol. Survey open-file rept. 77551.

Abstract. - - The coastal parts of Pasco, Pinellas and Hillsborough Counties are undergoing extensive urban development. The Floridan aquifer is the area's principal water supply. Potentiometric and water-table maps were prepared in order to determine the effects of ground-water withdrawals in selected well fields in west-central Florida.

These maps were prepared in September 1976 to capture the annual highwater-level period. Rises in the potentiometric surface ranged from 4 feet in the Cypress Creek and Starkey well fields to 26 feet in the Sun City well field.

, 1977, Water table in the surficial aquifer and potentiometric surface of the Floridan aquifer in selected well fields, west-central Florida, May 1977: U.S. Geol. Survey open-file rept. 77-642

Abstract. - - The coastal parts of Pasco, Pinellas and Hillsborough Counties are undergoing extensive urban development. The Floridan aquifer is the area's principal water supply. Maps of the potentiometric surface and of the water table were prepared in order to determine the effect of groundwater withdrawals in selected well fields in west-central Florida.

These maps were prepared from data collected in May 1971 to capture the annual low-water-level period. Declines since September 1976 in the potentiometric surface ranged from 3 feet in the Starkey well field to 25 feet in the Sun City well field. 
, 1978, Water table in the surficial aquifer and the potentiometric surface of the Floridan aquifer in selected well fields, westcentral Florida, September 1977: U.S. Geo1. Survey open-file rept. 78-311.

Abstract. - - The water table in the surficial aquifer and the potentiometric surface of the Floridan aquifer in a 1,200 square-mile area in west-central Florida are mapped semiannually by the U.S. Geological Survey. Maps are prepared on the basis of water levels measured in wells each May to coincide with seasonal low levels, and in September, when levels are high. The mapped area contains nine producing well fields which supplied 76.2 million gallons on September 21, 1977, to municipalities in the Tampa Bay area. The effect of localized withdrawal of ground water from the Floridan aquifer is shown on the maps as cones of depression in both the potentiometric and water-table surfaces.

In September, water levels in observation wells in the Floridan aquifer were above those measured in May. These increases ranged from about one foot at the Eldridge-Wilde well field to about 25 feet at the Sun City well field.

Ryder, P. D., Mills, L. R., and Woodham, W. M., 1978, Potentiometric surface of the Floridan aquifer, Southwest Florida Water Management District and adjacent areas, September 1977: U.S. Geol. Survey open-file rept. 78-9.

Abstract. A September 1977 potentiometric-surface map of the Southwest Florida Water Management District depicts the annual high water-level period.

Potentiometric levels increased 15-30 feet between May 1977 and September 1977, in the citrus and farming sections of southeastern Hillsborough, northern Hardee, and southwestern Polk Counties. These areas are widely affected by pumpage for irrigation and have the greatest range in water-level fluctuations between the low and high water-level periods. water-level rises in coastal, northern and southern areas of the water Management District ranged from $0-15$ feet.

Sinclair, William C., 1977, Experimental study of artificial recharge alternatives in northwest Hillsborough County, Florida: U.S. Geol. Survey Water-Resources Inv. 77-13.

Abstract. - Extensive water withdrawal from the Floridan aquifer in the urban Tampa Bay area has induced leakage from the overlying surficial aquifer adversely effecting the water table and lake levels. Artificial recharge could reduce the impact of these adverse effects. Four experiments were conducted to investigate possible recharge alternatives; sinkhole recharge, water-spreading, connector wells, and subsurface-tile drainage to a deep well. Experiments indicate that all four methods can be effective. However, the sinkhole recharge experiment moved the greatest volume of water into the Floridan aquifer. The drain-tile experiment indicated 
greatest potential for draining the surficial aquifer. Combinations of the four methods could be used where potential exists for downward movement of water and sufficient unsaturated aquifer for water storage.

Stewart, J. W., 1978, Areas of recharge to the Floridan aquifer in Florida: Florida Bur. Geol. Map Series.

Abstract. -- The Floridan aquifer, the most extensive and widely used aquifer system in Florida, consists chiefly of limestone and dolomite. The aquifer is at or near land surface in northwest and north-central Florida and about 1,000 feet below land surface in northwest and south Florida. It is overlain by surficial materials ranging in thickness from a few feet to several hundred feet. Water is unconfined in the surficial aquifer and confined in the Floridan aquifer.

Three relative types of classifications are used to delineate natural recharge areas of the Floridan aquifer: least effective, moderately effective, and most effective. The least effective recharge areas are areas of artesian flow where the potentiometric surface of the Floridan aquifer is above land surface and recharge of the aquifer can not occur under natural conditions. About 50 percent of the State falls within this classification. The moderately effective recharge areas represent about 35 percent of the State and recharge rates are estimated to range from less than 1 to 10 inches per year. The most effective areas represent about 15 percent of the State and recharge rates range from about 10 to 20 inches per year.

U.S. Geological Survey, 1977, Water-resources data for Florida, 1976, volume 3: Southwest Florida: U.S. Geo1. Survey WRD/HD-77/023.

Abstract. - - Water resources data for the 1976 water year in southwest Florida consist of discharge records for 70 streams, stage-only records for 31 streams, elevations for 107 lakes, and daily water level measurements for 352 wells. Water quality data for approximately 220 surface sites and 700 wells are included; as are miscellaneous measurement and crest-stage partial records.

These data represent the National Water Data System records collected by the U.S. Geological Survey and cooperating local, state and federal agencies in Florida.

Wilson, W. E., 1977, Hydrologic data for a subsurface waste-injection site at Mulberry, Florida, 1972-76: U.S. Geol. Survey open-file rept. 77-511.

Abstract. -- Beginning in October 1972, industrial waste has been injected into a limestone and dolomite brine aquifer 4,000-5,000 feet below land surface. During October 1975 through December 1976, the injection rate was about 8.2 million gallons per month. To determine what effect, if any, the injected waste is having on the ground-water body, water levels have been measured and water samples collected from two monitor wells that tap two 
different permeable zones above the injection zone, and from a satellite monitor well that taps the injection zone. The two monitor wells are installed in the annulus of the injection well and the satellite monitor well is 2,291 feet distant from the injection well.

Water levels in the satellite monitoring well fluctuate in response to changes in the injection rate. Water levels in the monitor wells fluctuate in response to variations in recharge to and discharge from aquifers above the injection interval, from seasonal rainfall and from well discharge. In the shallow annulus monitor well, water levels fluctuate about 25 feet annually compared with about 2 feet in the deep annulus monitor well.

Chemical analyses of water samples from all monitor wells show variations in concentration of constituents from time to time but no overall change.

, 1977, Simulated changes in ground-water levels resulting from proposed phosphate mining, west-central Florida--Preliminary results: U.S. Geol. Survey open-file rept. 77-882.

Abstract. -- A digital model of two-dimensional ground-water flow was used to simulate projected changes in the Floridan aquifer potentiometric surface in 1985 and 2000, resulting from proposed ground-water developments by the phosphate mining industry in west-central Florida. The model was calibrated under steady-state conditions to simulate the September 1975 potentiometric surface. Under one development plan, existing phosphate mines in Polk County would continue to withdraw ground water at 1975 rates, until phased out as the ore is depleted; no new mines would be introduced. Preliminary results indicate that under this plan, maximum simulated recovery of the potentiometric surface is 11.9 feet by 1985 and 36.5 feet by 2000 . Under an alternative plan, all proposed mines in Polk, Hardee, DeSoto, Hillsborough and Manatee Counties would begin operations, in addition to the continuation and phasing out of existing mines. Preliminary results indicate that the potentiometric surface would generally recover in Polk County and decline elsewhere in the modeled area. Maximum simulated recovery is 4.5 feet by 1985 and 29.6 feet by 2000; maximum simulated drawdown is 15.1 beet by 1985 and 14.4 feet by 2000 . All results are preliminary and subject to revision as the investigation continues. 
REPORTS RELEASED BY THE U.S. GEOLOGICAL SURVEY, 1933-77

This section lists reports produced by the U.S. Geological Survey concerning southwest Florida, and where applicable, Florida in its entirety, during the period, 1933-77. The reports are listed according to categories of investigations described in the section of the report entitled "Summary of Water Resources Investigations".

\section{Area1 Assessment}

Barraclough, J. T., and Marsh, 0. T., 1962, Aquifers and quality of ground water along the gulf coast of western Florida: Florida Geol. Survey Rept. of Inv. 29.

Bishop, E. W., 1956, Geology and ground-water resources of Highlands County, Florida: Florida Geol. Survey Rept. of Inv. 15.

Bredehoeft, J. D., Papadopulos, S. S., and Stewart, J. W., 1965, Hydrologic effects of ground-water pumping in northwest Hillsborough County, Florida: U.S. Geol. Survey open-file rept. FL-65001.

Cathcart, J. B., 1963, Economic geology of the Chicora quadrangle, Florida: U.S. Geol. Survey Bul1. 1162-A, p. Al-A66.

, 1963, Economic geology of the Keysville quadrangle, Florida: U.S. Geol. Survey Bu11. 1128.

, 1963, Economic geology of the Plant City quadrangle, Florida: U.S. Geo1. Survey Bu11. 1142-D, p. D1-D56.

, 1964, Economic geology of the Lakeland quadrangle, Florida:

U.S. Geol. Survey Bul1. 1162-G, p. G1-G128.

, 1966, Economic geology of the Fort Meade quadrangle, Polk and Hardee Counties, Florida: U.S. Geol. Survey Bull. 1207.

Cherry, R. N., Stewart, J. W., and Mann, J. A., 1968, General hydrology of the middle gulf area, Florida: Florida Geol. Survey Rept. of Inv. 56.

Clark, W. E., 1964, Possibility of salt-water leakage from proposed Intracoastal Waterway near Venice, Florida, well field: Florida Geol. Survey Rept. of Inv. 38.

Coble, R. W., 1974, The Anclote and Pithlachascotee Rivers as watersupply sources: Florida Bur. Geol. Map Series 61.

Duerr, A. D., 1975, The potentiometric surface and water quality of the Floridan aquifer in southwest Hillsborough County, Florida, 1952-74: U.S. Geol. Survey Water-Resources Inv. 50-75, map.

Faulkner, G. L., 1972, Mid 1971 ground-water conditions in Yankeetown well field, Levy County, Florida: U.S. Geol. Survey open-file rept. FL-72001. 
, 1972, Ground-water conditions in the lower Withlacoochee River--Cross-Florida Barge Canal complex: U.S. Geol. Survey WaterResources Inv. 4-72.

, 1973, Geohydrology of the Cross-Florida Barge Canal area with special reference to the Ocala vicinity: U.S. Geol. Survey WaterResources Inv. 1-73.

Healy, H. G., 1975, Potentiometric surface and areas of artesian flow of the Floridan aquifer in Florida: Florida Bur. Geol. Map Series 73.

, 1976, Terrace map of Florida: Florida Bur. Geol. Map Series 71.

Heath, Ralph C., and Smith, P. C., 1954, Ground-water resources of Pinellas County, Florida: Florida Geol. Survey Rept. of Inv. 12.

Hughes, G. H., Hampton, E. R., and Tucker, D. F., 1971, Annual and seasona1 rainfall in Florida: Florida Bur. Geol. Map Series 40.

Hutchinson, C. B., 1977, Appraisal of shallow Ground-water resources and management alternatives in the upper Peace and Eastern Alafia River Basins, Florida: U.S. Geol. Survey Water Resources Inv. 77-124.

Hutchinson, C. B., and Mills, L. R., 1976, Potentiometric surface of the Floridan aquifer and water table in the surficial aquifer, May 1976: U.S. Geo1. Survey open-file rept. 77-257.

Hutchinson, C. B., and Wilson, W. E., 1974, Evaluation of a proposed connector we11, northeastern DeSoto County, Florida: U.S. Geol. Survey Water-Resources Inv. 5-74.

Joyner, B. F., and Sutcliffe, H., Jr., 1976, Water resources of Myakka River basin area, Florida: U.S. Geo1. Survey Water-Resources Inv. 76-58.

Kaufman, M. I., 1967, Hydrologic effects of ground-water pumpage in the Peace and Alafia River basins, Florida: Florida Geol. Survey Rept. of Inv. 46.

Kaufman, M. I., and Dion, N. P., 1968, Ground-water resources data, Charlotte, DeSoto, and Hardee Counties, Florida: Florida Geol. Survey Inf. Circ. 53.

Knochenmus', D. D., 1967, Tracer studies and background fluorescence of ground water in the Ocala, Florida area: U.S. Geol. Survey openfile rept. FL-67004.

, 1971, Ground water in Lake County, Florida: Florida Bur. Geol. Map Series 44.

Knochenmus, D. D., and Hughes, G. H., 1976, Hydrology of Lake County, Florida: U.S. Geol. Survey Water-Resources Inv. 76-72.

Kohout, F. A., and Meyer, F. W., 1959, Hydrologic features of the Lake Istokpoga and Lake Placid areas, Highlands County, Florida: Florida Geo1. Survey Rept. of Inv. 19.

Menke, C. G., Meredith, E. W., and Wetterha11, W. S., 1961, Water resources of Hillsborough County, Florida: Florida Geol. Survey Rept of Inv. 25. 
Mills, L. R., Duerr, A. D., and Buono, Anthony, 1975, Potentiometric surface of the Floridan aquifer, May 1975; well field pumpage; and selected hydrographs; Hillsborough County, Florida: U.S. Geol. Survey open-file rept. 75-618.

Mills, L. R., and Laughlin, C. P., 1976, Potentiometric surface of the Floridan aquifer, May 1975, and change of the potentiometric surface, 1969 to 1975, Southwest Florida Water Management District and adjacent areas: U.S. Geol. Survey Water-Resources Investigations 76-80, map.

Mills, L. R., Laughlin, C. P., and Parsons, D. C., 1976, Potentiometric surface of the Floridan aquifer, Southwest Florida Water Management District, September 1975: U.S. Geol. Survey open-file rept. 76-003.

Motz, L. H., 1974, The hydrologic effects of the Tampa By-Pass Cana1: Florida Bur. Geol. Rept. of Inv. 82.

Parker, G. G. and others, 1955, Water resources of southeastern Florida, with special reference to the geology and ground water of the Miami area: U.S. Geol. Survey Water-Supply Paper 1255.

Pascale, C. A., 1975, Estimated yield of fresh-water wells in Florida: Florida Bur. Geol. Map Series 70.

Peek, H. M., 1951, Cessation of flow of Kissengen Spring, Polk County, Florida: Florida Geol. Survey Rept. of Inv. 7, pt. 3.

, 1958, Ground-water resources of Manatee County, Florida:

Florida Geol. Survey Rept. of Inv. 18.

, 1959, The artesian water of the Ruskin area of Hillsborough County, Florida: Florida Geol. Survey Rept. of Inv. 21.

Peek, H. M., and Anders, R. B., 1955, Interim report on the ground-water resources of Manatee County, Florida: Florida Geol. Survey Inf. Circ. 6.

Pride, R. W., Meyer, F. W., and Cherry, R. N., 1961, Interim report on the hydrologic features of the Green Swamp area in central Florida: Florida Geol. Survey Inf. Circ. 26.

, 1966, Hydrology of the Green Swamp area in central Florida: Florida Geol. Survey Rept. of Inv. 42.

Purdue, C. L., Jr., 1968, Summary report on the geological mineral resources of the Passage Key, Island Bay, Cedar Key, and Pelican Island National Wildlife Refuges, Florida: U.S. Geol. Survey Bu11. 1260-0, p. 01-013.

Robertson, A. F., 1973, Hydrologic conditions in the Lakeland Ridge area of Polk County, Florida: Florida Bur. Geol. Rept. of Inv. 64.

Robertson, A. F., and Ma11ory, M. J., 1977, A digital model of the Floridan aquifer, Tampa Bay area, Florida: U.S. Geol. Survey Water-Resources Inv. 77-64. 
Robertson, A. F., and Mi11s, L. R., 1975, Ground-water withdrawals in the upper Peace and upper Alafia River basins, Florida: Florida Bur. Geo1. Map Series 67.

Rosenau, J. C., and Faulkner, G. L., 1974, An index to springs of Florida: Florida Bur. Geol. Map Series 63.

Ryder, P. D., Laughlin, C. P., and Mills, L. R., 1976, Potentiometric surface of the Floridan aquifer, Southwest Florida Water Management District, September 1976: U.S. Geol. Survey open-file rept. 77-353.

, 1977, Potentiometric surface of the Floridan aquifer, Southwest F1orida Water Management District, May 1977: U.S. Geo1. Survey openfile rept. 77-552.

Ryder, P. D., and Mills, L. R., 1977, Potentiometric surface of the Floridan aquifer and water table in the surficial aquifer in selected well fields, May 1976: U.S. Geol. Survey open-file rept. 77-257.

, 1977, Potentiometric surface of the Floridan aquifer and water table in the surficial aquifer in selected well fields, September 1976: U.S. Geol. Survey open-file rept. 77-551.

, 1977, Potentiometric surface of the Floridan aquifer, and water table in the surficial aquifer in selected well fields May 1977: U.S. Geol. Survey open-file rept. 77-642.

, 1978, Potentiometric surface of the Floridan aquifer, and water table in the surficial aquifer in selected well fields, September, 1977: U.S. Geol. Survey open-file rept. 78-311.

Ryder, P. D., Mills, L. R., and Woodham, W. M., 1978, Potentiometric surface of the Floridan aquifer, Southwest Florida Water Management District and adjacent areas, September 1977: U.S. Geol. Survey open-file rept. 78-9.

Sinclair, William C., 1974, Hydrogeologic characteristics of the surficial aquifer in northwest Hillsborough County, Florida: Florida Bur. Geol. Inf. Circ. 86.

, 1977, Experimental study of artificial recharge alternatives in northwest Hillsborough County, Florida: U.S. Geol. Survey WaterResources Inv. 77-13.

Stewart, H. G., Jr., 1959, Interim report on the geology and ground-water resources of northwestern Polk County, Florida: Florida Geol. Survey Inf. Circ. 23.

, 1966, Ground-water resources of Polk County: Florida Geol. Survey Rept. of Inv. 44.

Stewart, J. W., 1968, Hydrologic effects of pumping from the Floridan aquifer in northwest Hillsborough, northeast Pinellas, and southwest Pasco Counties, Florida: U.S. Geol. Survey open-file rept. FL-68005. 
, 1978, Areas of recharge to the Floridan aquifer in Florida: Florida Bur. of Geol. Map series.

Stewart, J. W., and Hughes, G. H., 1974, Hydrologic consequences of using ground water to maintain lake levels affected by water wells near Tampa, Florida: Florida Bur. Geol. Rept. of Inv. 74.

Stewart, J. W., Laughlin, C. P., and Mil1s, L. R., 1976, Potentiometric surface of the Floridan aquifer, Southwest Florida Water Management District, May 1976: U.S. Geol. Survey open-file rept. FL-76004, map.

Stewart, J. W., Mills, L. R., Knochenmus, D. D., and Faulkner, G. L., 1971, Potentiometric surface and areas of artesian flow, May 1969, and change of potentiometric surface 1964 to 1969, Floridan aquifer, Southwest Florida Water Management District, Florida: U.S. Geol. Survey Hydrol. Inv. Atlas HA-440.

Stringfield, V. T., 1933, Ground-water resources of Sarasota County, Florida, and exploration of artesian wells in Sarasota County, Florida: Florida Geol. Survey, in 23rd-24th Annual Rept.

Sutcliffe, H., Jr., 1975, Appraisal of the water resources of Charlotte County, Florida: Florida Bur. Geol. Rept. of Inv. 78.

Sutcliffe, H., Jr., and Joyner, B. F., 1968, Test we11 exploration in the Myakka River basin area, Florida: Florida Geol. Survey Inf. Circ. 56.

Taylor, R. L., 1953, Hydrologic characteristics of Lake Tarpon area, Florida: U.S. Geo1. Survey open-file rept. FL-53001.

Tibbals, C. H., 1975, Aquifer tests in the summit reach of the proposed Cross-Florida Barge Canal near Ocala, Florida: U.S. Geo1. Survey Water-Resources Inv. 28-75.

Vernon, R. O., 1973, Top of the Floridan artesian aquifer: Florida Bur. Geol. Map Series 56.

Visher, F. N., and Hughes, G. H., 1969 (revised 1975), The difference in rainfall and potential evaporation in Florida: Florida Bur. Geol. Map Series 32.

Wilson, W. E., 1972, Hydrogeology of Florida's largest citrus grove: American Soc. of Civil Engineers, Irrigation and Drainage Div. Speciality Conf. proc., p. 293-307.

, 1975, Ground-water resources of DeSoto and Hardee Counties, Florida: Florida Bur. Geo1. Rept. of Inv. 83.

1977, Simulated changes in ground-water levels resulting from proposed phosphate mining, west-central Florida--Preliminary results: U.S. Geol. Survey open-file rept. 77-882. 
Conover, C. S., and Leach, S. D., 1975, Drainage basins in Florida: Florida Bureau of Geol. Map Series 72.

Duerr, A. D., 1974, Hydrologic data from wells in southwest Hillsborough County, Florida, 1950-74: U.S. Geol. Survey open-file rept. FL-74031.

, 1975, Water levels in wells that tap the Floridan aquifer in southwest Hillsborough County, Florida, May 1974 and May 1975: U.S. Geol. Survey open-file rept. FL-75002.

Healy, H. G., 1960, Water levels in artesian and nonartesian aquifers of Florida in 1960: Florida Geol. Survey Inf. Circ. 33.

, 1966, Water levels in artesian and nonartesian aquifers in Florida, 1961-62: Florida Geo1. Survey Inf. Circ 48.

, 1968, Water levels in artesian and nonartesian aquifers in Florida, 1963-64: Florida Geo1. Survey Inf. Circ. 52.

, 1970, Water levels in artesian and nonartesian aquifers of Florida, 1967-68: Florida Bur. Geol. Inf. Circ. 68.

, 1971, Water levels in artesian and nonartesian aquifers in Florida, 1965-66: Florida Bur. Geol. Inf. Circ 61.

, 1972, Water levels in artesian and nonartesian aquifers of Florida, 1969-70: Florida Bur. Geol. Inf. Circ. 73.

, 1972, Public water supplies of selected municipalities in Florida, 1970: Florida Bur. Geol. Inf. Circ. 81.

, 1974, The observation well network of the U.S. Geological

Survey in Florida: Florida Bur. Geol. Map Series 65.

, 1974, Water levels in artesian and nonartesian aquifers of Florida, 1971-72: Florida Bur. Geol. Inf. Circ. 85.

, 1976, Water levels in artesian and nonartesian aquifers of Florida, 1973-74: U.S. Geo1. Survey Water-Resources Inv. 76-101.

Healy, H. G., 1977, Public water supplies of selected municipalities in Florida, 1975: U.S. Geol. Survey Water Resources Inv. 77-53.

Heath, Richard C., 1961, Surface-water resources of Polk County, Florida: Florida Geol. Survey Inf. Circ. 25.

Hughes, G. H., 1975, Perspective use of fresh water for cooling systems of thermoelectric power plants in Florida: U.S. Geol. Survey WaterResources Inv. 43-75.

Kenner, W. E., Pride, R. W., and Conover, C. S., 1967, Drainage basins in Florida: Florida Geol. Survey Map Series 28.

Laughlin, C. P., and Hughes, D. M., 1974, Hydrologic records for Lake County, Florida: U.S. Geol. Survey open-file rept. FL-74018. 
Laughlin, C. P., and Scho1, M. C., 1971, Hydrologic records for Lake County, Florida, 1970-71: U.S. Geol. Survey open-file rept. FL-71011. , 1973, Hydrologic records for Lake County, Florida, 1971-72: U.S. Geo1. Survey open-file rept. FL-73009.

Leach, S. D., 1977, Sources, use, and disposition of water in Florida, 1975: U.S. Geo1. Survey open-file rept. 77-577.

Murphy, W. R., 1968, Causes of flooding of Little Charlie Bowlegs Creek upstream from Highlands Hammock State Park, Florida: U.S. Geol. Survey open-file rept. FL-68004.

Peek, H. M., 1958, Record of we1ls in Manatee County, Florida: Florida Geo1. Survey Inf. Circ. 19.

, 1959, Record of wells in the Ruskin area, Hillsborough County, Florida: Florida Geol. Survey Inf. Circ. 22.

Pride, R. W., 1970 (Second edition 1975), Estimated water use in Florida, 1965: Florida Bur. Geol. Map Series 36. , 1973, Estimated water use in Florida, 1970: Florida Bur. Geo1. Inf. Circ. 83.

Rabon, J. W., 1970, Evaluation of streamflow data program in Florida: U.S. Geol. Survey open-file rept. FL-70008.

Robertson, A. F., and Mills, L. R., 1975, Ground-water withdrawals in the upper Peace and the upper Alafia River Basins, Florida: Florida Bur. Geo1. Map Series 67.

Stewart, H. G., 1963, Records of wells and other water-resources data in Polk County, Florida: Florida Geol. Survey Inf. Circ. 38.

U.S. Geological Survey, Surface water records of Florida, Volume 1, Streams: 1961, 1962, 1963, 1964.

, Surface water records of Florida, Volume 2, Lakes: 1961, $1962,1963,1964$.

, Water resources data for Florida, Part 1, Surface water records, Volume 1, Streams: 1965.

, Water resources data for Florida, Part 1, Surface water records, Volume 2, Lakes: 1965.

, Water resources data for Florida, Part 1, Surface water records, Volume 1, Streams--northern and central Florida: 1966, 1967, 1968, 1969, 1970, 1971, 1972, 1973, 1974.

, Water resources data for Florida, Part 1, Surface water records, Volume 2, Streams--southern Florida, Lake Okeechobee and the Everglades: 1966, 1967, 1968, 1969, 1970, 1971, 1972.

, Water resources data for Florida, Part 1, Surface water records, Volume 3, Lakes: 1966, 1967, 1968, 1969, 1970, 1971, 1972, 1973, 1974. 
, Water resources data for Florida, Part 2, Water quality records: 1965, 1966, 1967, 1968, 1969, 1970, 1971, 1972, 1973, 1974.

, Water resources data for Florida, Volume 3, west-central Florida, surface water, ground water, quality of water: 1975. , Water resources data for Florida, Volume 3, southwest Florida, surface water, ground water, quality of water: 1976.

\section{Quality and Flow Characteristics of Streams}

Anderson, Warren, 1971 (revised 1975), Temperature of Florida streams: Florida Bur. Geo1. Map Series 43.

Anderson, Warren, and Faulkner, G. L., 1973, Quantity and quality of surface water in Marion County, Florida: Florida Bur. Geol. Map Series 55.

Flippo, H. N., Jr., and Joyner, B. F., 1968, Low streamflow in the Myakka River basin area in Florida: Florida Geol. Survey Rept. of Inv. 53.

Heath, Richard C., and Wimberly, E. Turner, 1971, Selected flow characteristics of Florida streams and canals: Florida Bur. Geol. Inf. Circ. 69.

Higer, A. L., and Kolipinski, M. C., 1970, Sources of pesticides in Florida waters: U.S. Geo1. Survey open-file rept. FL-70005.

Joyner, B. F., 1973, Nitrogen, phosphorus, and trace elements in Florida surface waters, 1970-71: U.S. Geol. Survey open-file rept. FL-73028.

Kaufman, M. I., 1969 (revised 1975), Color of water in Florida streams and canals: Florida Bur. Geol. Map Series 35.

, 1969 (revised 1975), General distribution and concentration of orthophosphate in Florida streams: Florida Bur. Geol. Map Series 33.

, 1970 (revised 1975), The $\mathrm{pH}$ of water in Florida streams and cana1s: Florida Bur. Geol. Map Series 37.

1972 (revised 1975), The chemical type of water in Florida streams: Florida Bur. Geol. Map Series 51.

Kenner, W. E., 1969 (revised 1975), Seasonal variations of streamflow in Florida, 1969: Florida Geol. Survey Map Series 31.

Kenner, W. E., Hampton, E. R., and Conover, C. S., 1969 (revised 1975), Average flow of major streams in Florida: Florida Bur. Geol. Map Series 34.

Pride, R. W., and Crooks, J. W., 1962, The drought of 1954-56 -- Its effect on Florida's surface-water resources: Florida Geol. Survey Rept. of Inv. 26. 
Rabon, J. W., 1967, Inflow-outflow characteristics of Lake Rosseau (Inglis Reservoir) on Withlacoochee River, Florida: U.S. Geol. Survey open-file rept. FL-67002.

Slack, L. J., and Kaufman, M. I., 1973 (revised 1975), Specific conductance of water in Florida streams and canals: Florida Bur. Geol. Map Series 58.

Sne11, L. J., and Kenner, W. E., 1974, Surface-water features of Florida: Florida Bur. Geol. Map Series 66.

Spitzer, P. R., Kolipinski, M. C., and Higer, A. L., 1969, Annotated bibliography of pesticides in Florida: U.S. Geol. Survey open-file rept. FL-69006.

Stone, R. B., 1974, Low streamflow in Florida--magnitude and frequency: Florida Bur. Geol. Map Series 64.

\section{Flood Hazard}

Bridges, W. C., 1977, Progress report on magnitude and frequency of floods on small drainage areas in Florida: U.S. Geol. Survey Water-Resources Inv. 77-478.

Murphy, W. R., 1977, Flood profiles of lower Brooker Creek, west-central Florida: U.S. Geol. Survey Water-Resources Inv. 77-115.

Pride, R. W., 1957, Flood-frequency relations for Florida: U.S. Geol. Survey open-file rept. FL-57001.

, 1958, Floods in Florida: U.S. Geol. Survey Water-Supply Paper 1674 .

Robertson, A. F., 1977, Flood profiles of the Alafia River, west-central Florida, computed by step-backwater method: U.S. Geol. Survey Water-Resources Inv. open-file rept. 77-74.

Turner, J. F., Jr., 1972, Hydrograph simulation models of the Hillsborough and Alafia Rivers, Florida: A preliminary report: U.S. Geol. Survey open-file rept. FL-74025.

, 1973, Flood profiles of the lower Hillsborough River, Florida: U.S. Geol. Survey open-file rept. FL-74003.

\section{Quality Characteristics of Aquifers}

Brown, D. W., 1958, Interim report on the changes in the chloride content of ground water in Pinellas County, Florida between 1947 and 1956: Florida Geol. Survey Inf. Circ. 16.

Bush, P. W., 1972, Salt-water movement in the lower Withlacoochee River-Cross-Florida Barge Canal complex: U.S. Geol. Survey Water-Resources Inv. 5-72. 
Cherry, R. N., 1966, Chloride content of ground water in Pinellas County, Florida in 1950 and 1963: Florida Geol. Survey Map Series 20.

Irwin, G. A., and Hutchinson, C. B., 1976, Radium-226 reconnaissance water sampling of eight Florida counties, December 1974 - January 1975: U.S. Geo1. Survey Water-Resources Inv. 76-103.

Kaufman, M. I., and Dion, N. P., 1967, Chemical character of water in the Floridan aquifer in southern Peace River basin, Florida, 1967: Florida Geol. Survey Map Series 27.

Klein, Howard, 1971 (revised 1975), Depth to base of potable water in the Floridan aquifer: Florida Bur. Geo1. Map Series 42.

Mills, L. R., and Ryder, P. D., 1977, saltwater intrusion in coastal Citrus and Hernando Counties, Florida, 1975: U.S. Geol. Survey WaterResources Inv. open-file rept. 77-100.

Reichenbaugh, R. C., 1972, Sea-water intrusion in the upper part of the Floridan aquifer in coastal Pasco County, F1orida, 1970: Florida Bur. Geol. Map Series 47.

Shattles, D. E., 1965, Quality of water from the Floridan aquifer in Hillsborough County, Florida, 1963: Florida Geol. Survey Map Series 9.

Toler, L. G., 1967, Fluoride in water in the Alafia and Peace River basins, Florida: Florida Geol. Survey Rept. of Inv. 46.

\section{Utilization of Subsurface Space}

Hickey, J. J., 1977, Hydrogeologic data for the McKay Creek waste-injection test site, Pinellas County, Florida: U.S. Geol. Survey WaterResources Inv, 77-802.

Rosenshein, J. S., and Hickey, J. J., 1977, Storage of treated sewage effluent and treated storm water in a saline aquifer: Ground Water Jour., vol. 15, no. 4, p. 284-293.

Wilson, W.'E., 1976, Hydrologic data for a subsurface waste-injection site at Mulberry, Florida: U.S. Geol. Survey open-file rept. 76-721.

, 1977. Hydrologic data for a subsurface waste-injection site at Mulberry, Florida, 1972-76: U.S. Geol. Survey open-file rept. 77-511.

\section{Land Use Hydrology}

Cherry, R. N., and Brown, D. P., 1973, Hydrogeologic aspects of a proposed sanitary landfill near 01d Tampa Bay, Florida: Florida Bur. Geol. Rept. of Inv. 68. 
Cherry, R. N., Brown, D. P., Stamer, J. K., and Goetz, C. L., 1973, Hydrobiochemical effects of spraying waste-treatment plant effluent in St. Petersburg, Florida: In Proceedings 1973 workshop: Land spreading municipal effluent and sludge in Florida; Instit. Food and Agr. Sci., Univ. of Florida, Gainesville.

Coker, A. E., and others, 1974, Automatic categorization of land-water cover types of the Green Swamp, Florida, using Skylab multispectral scanner (S-192) data: American Astronautical Society Annual Meeting.

Higer, A. L., Coker, A. E., and Jurado, Antonio, 1974, Three photo mosaics, (1) color mosaic state of Florida; (2) southeast Florida, (3) central Florida: U.S. Geol. Survey open-file rept. FL-74020.

Hutchinson, C. B., Stewart, J. W., 1977, Hydrogeology of Toytown landfill, St. Petersburg, Florida: U.S. Geol. Survey Water-Resources Inv. $77-78$.

Lamonds, A. G., 1976, Proposed Cross-Florida Barge Canal: Assessment of impacts of proposed transloading facility, barge fleeting area, and barge port on water quality: U.S. Geol. Survey open-file rept. 76-570.

Lamonds, A. G., with a section by M. L. Merritt, 1976, Proposed CrossFlorida Barge Canal--water quality aspects with a section on water assimilative capacity: U.S. Geo1. Survey Water-Resources Inv. $76-23$.

McPherson, B. F., 1973, Vegetation map of southern parts of subareas A and C, Big Cypress Swamp, Florida: U.S. Geol. Survey Hydrologic Inv. Atlas HA-492.

Reichenbaugh, R. C., 1976, Effects on ground-water quality from irrigating pasture land with sewage effluent near Lakeland, Florida: U.S. Geol. Survey Water-Resources Inv. 76-108.

Stewart, J. W., and Duerr, A. D., 1973, Hydrologic and geologic considerations for solid-waste disposal in west-central Florida: U.S. Geol. Survey Water-Resources Inv. 50-73.

Stewart, J. W., and Hanan, R. V., 1970, Hydrogeologic factors affecting the utilization of land for sanitary landfills in northern Hillsborough County, Florida: Florida Bur. Geol. Map Series 39.

8. Lake Hydrology

Bush, P. W., 1972, A hydrologic description of Lake Minnehaha at Clairmont, Florida: Florida Bur. Geo1. Map Series 54.

Hughes, G. H., 1973, Water-level fluctuations of lakes in Florida: Florida Bur. Geo1. Map Series 62.

Hunn, J. D., 1974, Hydrology of Lake Tarpon near Tarpon Springs, Florida: Florida Bur. Geol. Map Series 60. 
Hunn, J. D., and Reichenbaugh, R. C., 1972, A hydrologic description of Lake Magdaline near Tampa, Florida: Florida Bur. Geol. Map Series 49.

Kenner, W. E., 1961, Stage characteristics of Florida lakes: Florida Geol. Survey Inf. Circ. 31.

, 1964, Maps showing depths of selected lakes in Florida: Florida Geol. Survey Inf. Circ. 40.

Reichenbaugh, R. C., 1977, Hydrology of Keystone Lake in northwest Hillsborough County, Florida: U.S. Geol. Survey Water-Resources Inv. 76-124.

Reichenbaugh, R. C., and Hughes, G. H., 1977, Evaluation of chemical, biological, and physical conditions in the Winter Haven chain of lakes, Florida: U.S. Geol. Survey Water-Resources Inv. 77-52.

Reichenbaugh, R. C., and Hunn, J. D., 1972, Hydrologic description of Lake Thonotosassa near Tampa, Florida: Florida Bur. Geol. Map Series 48.

9. Estaurine and Wetland Hydrology

Coker, A. E., Higer, A. L., and Goodwin, C. R., 1976, Detection of turbidity dynamics in Tampa Bay, Florida: In ERTS-1: A new window on our planet, U.S. Geo1. Survey Prof. Paper 929, p. 330-333.

Goodwin, C. R., 1977, Circulation patterns for historical, existing, and proposed channel configurations in Hillsborough Bay, Florida: Proc. XXIV Internat'1 Navigation Congress, Lennigrad, 1977.

Goodwin, C. R., and Michaelis, D. M., 1975, Tides in Tampa Bay, Florida: June 1971 to December 1973: U.S. Geo1. Survey open-file rept. FL-75004.

Goodwin, C. R., Rosenshein, J. S., and Michaelis, D. M., 1974, Water quality of Tampa Bay, Florida: Dry-weather conditions, June 1971: U.S. Geo1. Survey open-file rept. FL-74026.

, 1974, Water quality of Tampa Bay, Florida: Wet-weather conditions, October 1971: U.S. Geol. Survey open-file rept. FL-75005.

Mann, J. A., 1971, Hydrologic aspects of freshing upper Old Tampa Bay, Florida: Florida Bur. Geol. Rept. of Inv. 76.

Reichenbaugh, R. C., Rosenshein, J. S., and Westley, R. W., 1973, Basic water quality data for pollution abatement plan, Tampa Bay area, Florida: U.S. Geol. Survey open-file rept. FL-73020.

Rosenshein, J. S., Goodwin, C. R., and Jurado, Antonio, 1975, Bottom configuration of Tampa Bay, Florida, as related to hydrologic evaluation of bay environment: Am. Soc. of Photogrammetry. 


\section{HYDROLOGIC SETTING}

Water is the major factor in a balanced ecologic system for southwest Florida. Rainfall, averaging from 50 to 55 in per year, is the primary source of freshwater. Infiltration and overland flow of rainfall recharges the aquifers and provides streamflow. Ninety percent of southwest Florida's water supply is obtained from ground water and the remaining 10 percent from surface water. Ground water is obtained from three principal aquifers in southwest Florida, the surficial, the minor artesian, and the Floridan aquifers (fig. 3). Ground water in the surficial aquifer is unconfined. Ground water is confined in the minor artesian and Floridan aquifers.

\section{Climate}

The climate of southwest Florida is subtropical and is characterized by warm, humid summers and relatively mild winters. While some rainfall normally occurs every month of the year in the Management District, there is a distinct rainy season extending from June through September, and a low rainfall season from October through May. About 60 percent of the annual rainfall occurs during the rainy season. The winter rainfall is the result of the cyclonic storms. Since Florida represents the normal southern limit of these storms, rainfall is relatively light. Summer rainfall is derived principally from convectional storms which usually occur in the afternoon and early evening. Geographically, summer rainfall is highly variable. Areas only a few miles apart of ten receive widely differing amounts of rain.

Climatological data at Lakeland is used to typify the area. The average annual temperature at Lakeland is $72.5^{\circ} \mathrm{F}$, with average monthly temperatures ranging from $62^{\circ} \mathrm{F}$ in January to $82^{\circ} \mathrm{F}$ in August. The rainfall at Lakeland averages 49.4 in with more than half occurring from June through September. Summer rains are typically intense late afternoon thundershowers of short duration. The rainfall at Lakeland for the calendar year 1977 was 41.5 in. Figure 4 shows the departure from normal at Lakeland for the period 1941-77. A more detailed description of the climate in the Management District is given in a report entitled "Water Use Plan, Southwest Florida Water Management District, Draft II, 1977."

\section{Topography and Drainage}

The Southwest Florida Water Management District is divided into ten drainage basins (fig. 1). Drainage of the area is dendritic and is characterized by many small lakes, ponds, and numerous marshlands. Stream density and runoff vary from low in the central highlands to high along the coast where numerous springs add to stream discharge. 


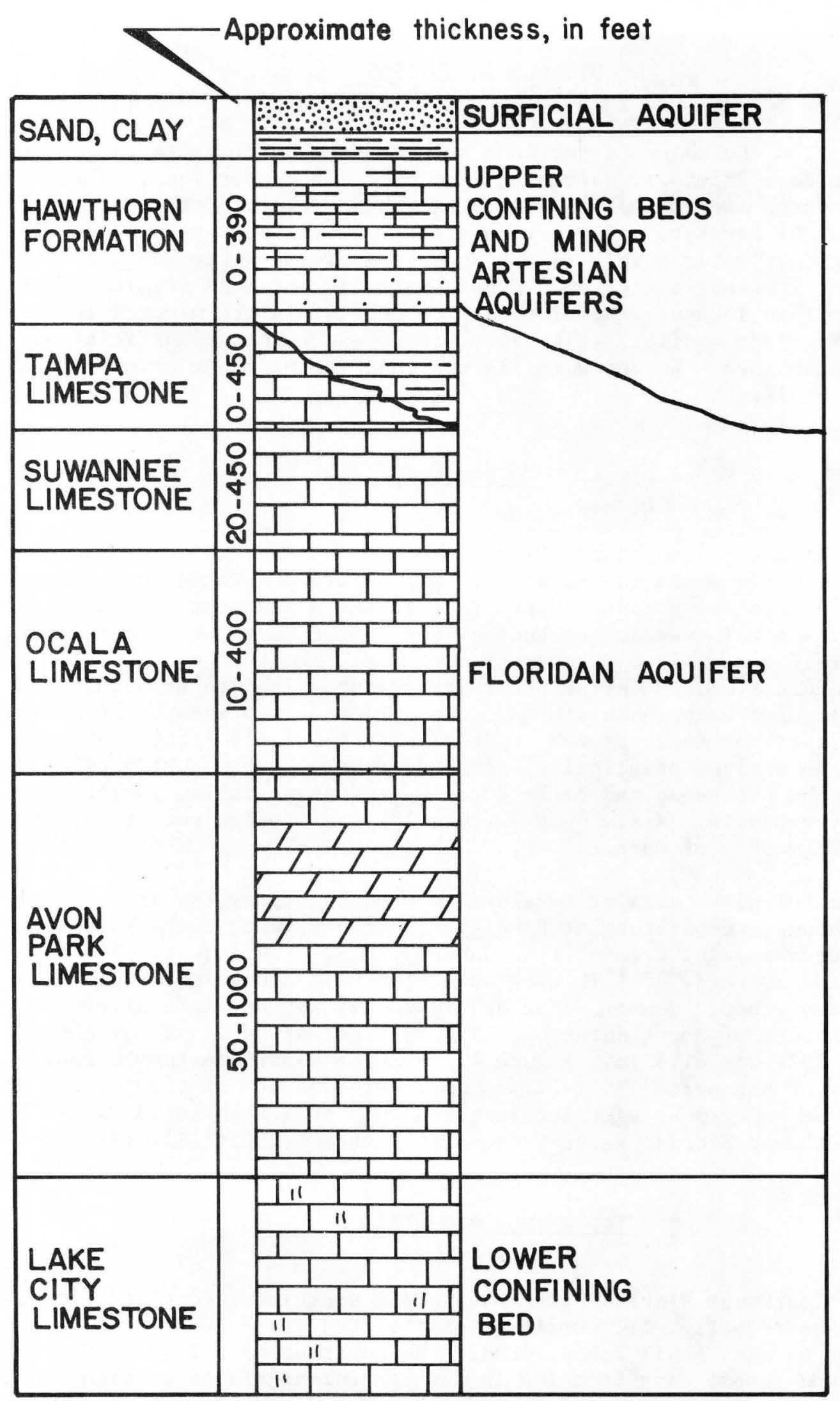

Figure 3. Generalized hydrogeologic section. 


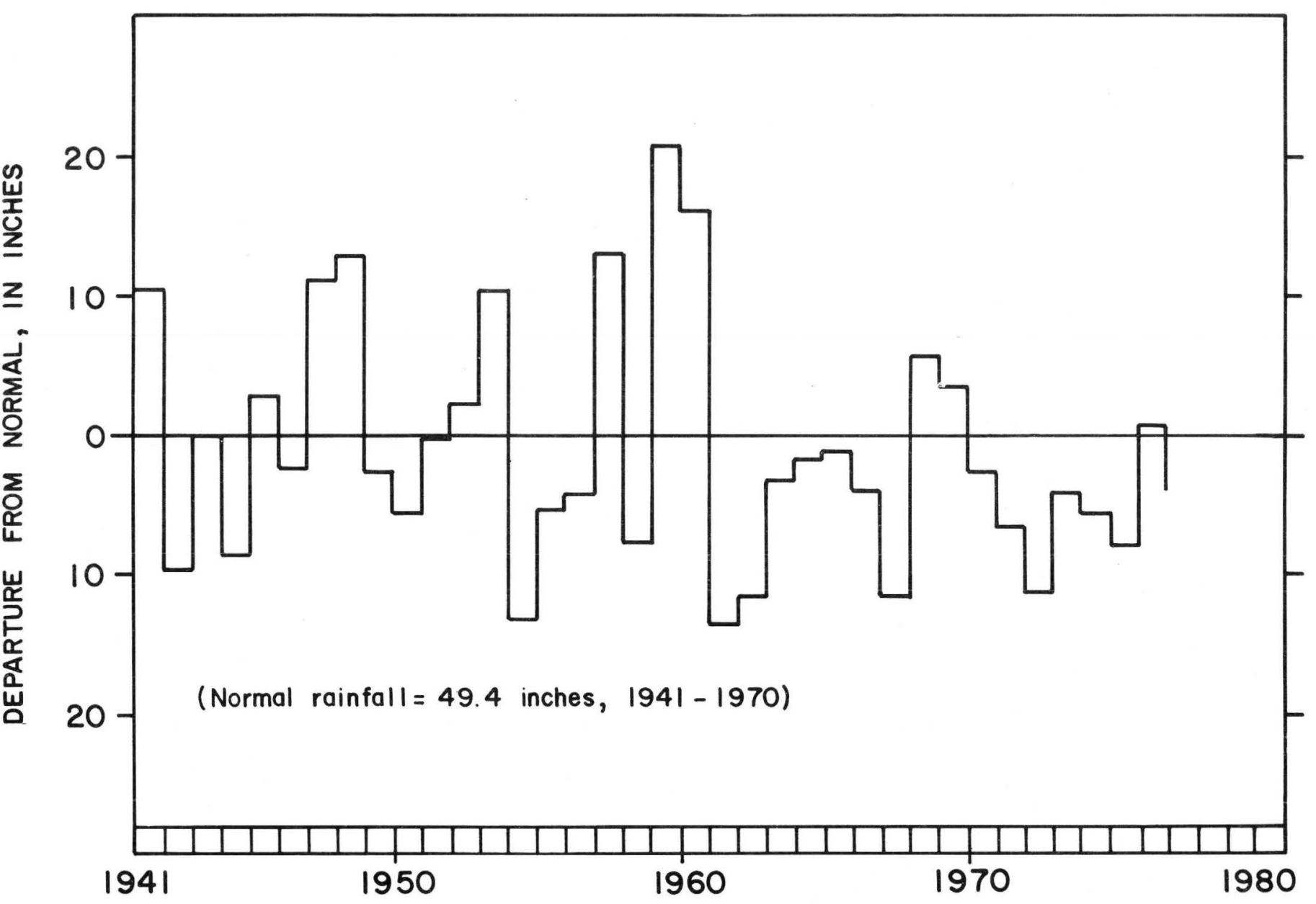

Figure 4. Rainfall departure from normal at Lakeland, 1941-77. 
Land elevations in the northern part of southwest Florida range from sea level along the coast to about $280 \mathrm{ft}$ above in eastern Pasco County. In the southern part, the elevation is above $200 \mathrm{ft}$ in several parts of Polk County, and reaches a maximum elevation of $305 \mathrm{ft}$.

Southwest Florida is characterized by relatively flat, swampy lowlands in the northern coastal areas and by gently rolling hills in the central and southern areas. Except for the coastal ridge of central Pinellas County, which reaches an elevation of almost $100 \mathrm{ft}$, the coastal lowlands are below $50 \mathrm{ft}$ in elevation. A series of eroded ridges trend northwestward from Dade City (fig. 5) toward a poorly defined area of sand hills that serves as a western topographic divide for the Withlacoochee River (fig. 5). Much of this ridge lies above $100 \mathrm{ft}$ elevation.

The extreme southern part of the area, consisting of the Myakka River basin and the lower Peace River basin, lies below $100 \mathrm{ft}$ in elevation. The topography is characterized by gently sloping marine terraces and is generally flat away from the streams. The Myakka flatlands contain many wetweather ponds and the Peace flatlands contain some swamps and much rolling hill country.

More than two-thirds of soythwest Florida is drained by nine rivers. The Peace River drains 2,400 $\mathrm{mi}^{2}$ and the Withlacoochee River drains 2,000 $\mathrm{mi}^{2}$. The western part of the district is drained by numerous coastal streams that flow directly into the Gulf of Mexico.

The Peace River heads in central Polk County at the confluence of Peace Creek Drainage Cana1 and Saddle Creek near Bartow and trends southward through Hardee and DeSoto Counties into Charlotte Harbor.

The Withlacoochee River, which drains about 80 percent of the Green Swamp, begins in a group of lakes and swamps in northern Polk County. The river turns north near Dade City and becomes ponded along its course in eastern Citrus County to form Tsala-Apopka Lake. The lake lies in a broad valley bounded on the southwest by high sand hills and on the northeast by a broad swamp. The river receives a large amount of water from Rainbow Springs in southeastern Marion County. Near its mouth in the vicinity of the Cross-Florida Barge Canal, the Withlacoochee River is dammed by Inglis Dam to form Lake Rousseau.

The Hillsborough River rises in the Green Swamp and flows southwestward to Tampa Bay. Of the many lakes and springs in the basin, most are west of the Cypress Creek tributary, north of Tampa. The Cypress Creek tributary basin is a large swampy area in northern Hillsborough and southern Pasco Counties. During. 1ow flow of the Hillsborough River, much of the water flowing in the channel is discharged from Crystal Springs in Pasco County.

The Myakka River drains a low area in the Manasota basin and flows through Upper and Lower Myakka Lakes near the center of the river basin. 


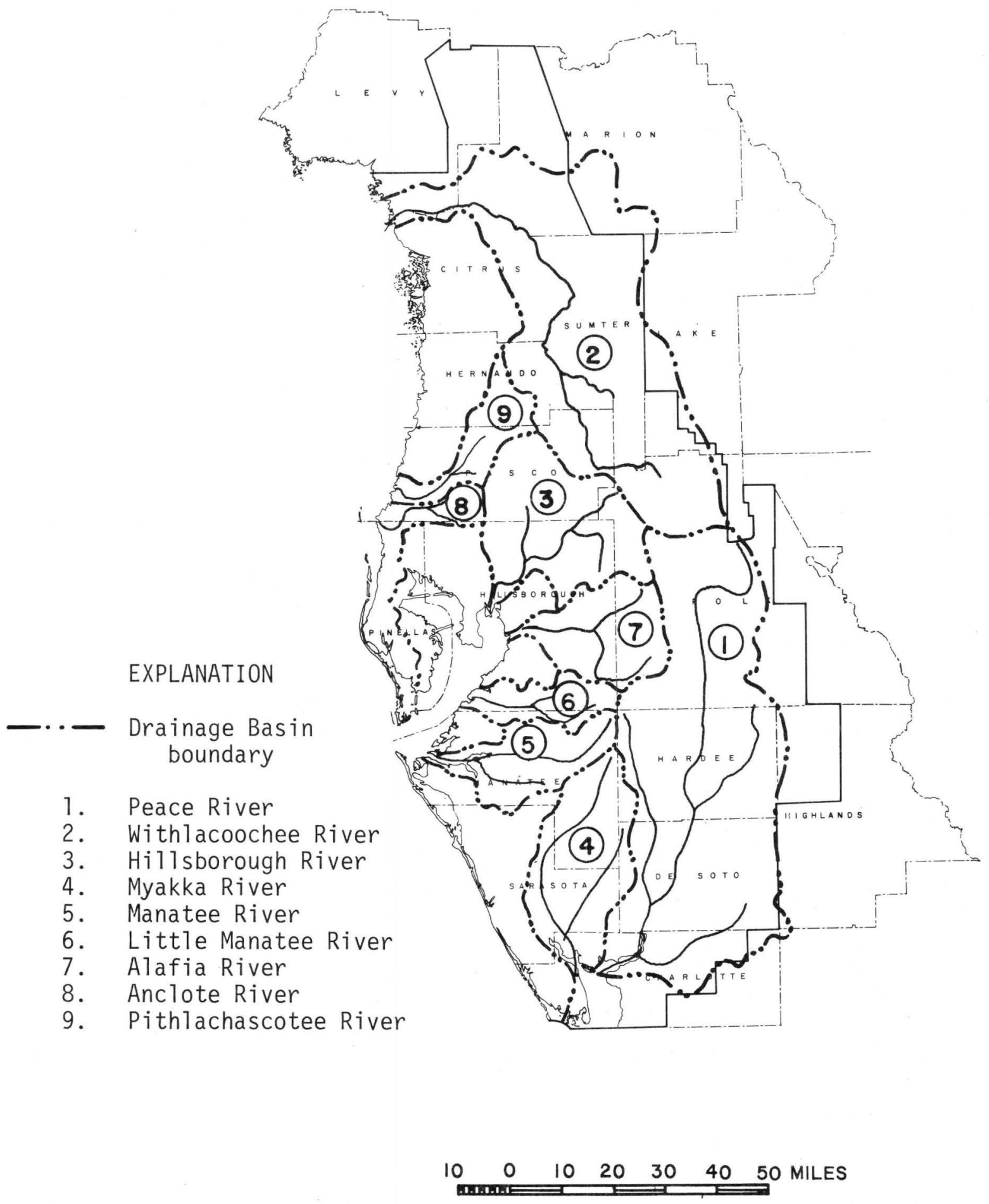

Figure 5. Major drainage basins in southwest Florida. 
The Manatee River and Little Manatee River drain the northern part of the Manasota Basin, an area characterized by a dendritic stream system. The Manatee River is impounded at Lake Manatee in central Manatee County for water supply.

The Alafia River begins in southern Hillsborough County and flows westward to Tampa Bay. Throughout most of its length, the river flows through a shallow but well-defined channel. The base flow of the river is sustained by numerous small springs along the channel and by Lithia Springs in the downstream part of the basin.

The Anclote River and Pithlachascotee River drain about $300 \mathrm{mi}^{2}$ of sand covered flatlands in the coastal areas located north of Tampa Bay. The area is dotted by depressions created by limestone sinks, the largest of which are in the upper Pithlachascotee River basin. Much of the rainfall in this area drains into sinks which recharge the underlying Floridan aquifer.

Streams in the northern part of the area generally originate as springs and receive little direct runoff. The largest of these streams is Crystal River which heads at a group of springs in the community of Crystal River.

\section{Floridan Aquifer}

The Floridan aquifer (fig. 3) is predominantly limestone and is the principal source of ground water in southwest Florida. The Floridan aquifer was defined to include all or parts of the Avon Park Limestone, Ocala Limestone, Suwannee Limestone, Tampa Limestone, and permeable parts of the Hawthorn Formation that are in hydrologic contact with the rest of the aquifer (Parker and others, 1955, p. 189). Wells tapping this aquifer yield as much as $5,000 \mathrm{gal} / \mathrm{min}$.

An important characteristic of the Floridan aquifer is represented by the potentiometric map. These maps illustrate the hydrostatic pressure in the aquifer. The contour 1ines, which connect points of equal hydrostatic pressure, indicate the approximate elevation to which water would rise in tightly cased wells that penetrate the aquifer. The U.S. Geological Survey publishes each May and September a map showing potentiometric surface of the Floridan aquifer in southwest Florida. Potentiometric maps for September 1976, May 1977, and September 1977 are shown on pages 66-68 of this report. 
Upper Confining Beds and Minor Artesian Aquifers

The principal formations beneath the surficial aquifer and overlying the Floridan aquifer are the Hawthorn Formation and, in places, unconsolidated sections of the Tampa Limestone (fig. 3). These formations, ranging from about 50 to $700 \mathrm{ft}$ in thickness, consist of a heterogeneous mixture of limestone, dolomite, sand, and clay. Permeable zones in the carbonate rocks of this section are minor confined aquifers producing several hundred gallons of water per minute from individual wells. The relatively impermeable, interbedded clay deposits act as confining beds for these aquifers and for the Floridan aquifer.

In the areas north of an east-west line passing approximately through Clearwater in Pinellas County, Tampa in Hillsborough County, and slightly to the north of both Lake Parker and Winter Haven in Polk County, the Hawthorn Formation is absent and the confining material overlying the Floridan aquifer is relatively thin or missing. This allows a greater degree of interaction between the Floridan aquifer and overlying aquifers. In areas south of the line, the Hawthorn Formation and unconsolidated sections of the Tampa Limestone are as thick as $700 \mathrm{ft}$, effectively inhibiting vertical movement of water into or out of the Floridan aquifer.

\section{Surficial Aquifer}

The surficial aquifer (fig. 3) underlies most of southwest Florida and consists predominantly of fine sand and clayey sand. Ground water in the surficial aquifer fills the pore spaces between the grains of sand and clay. The uppermost surface of the zone of saturation is at atmospheric pressure. This surface, called the water table, is irregularly shaped and follows the topography of the land surface in a subdued fashion.

The thickness of the sandy material which comprises this aquifer generally ranges between 0 and $50 \mathrm{ft}$ with thicknesses greater than $200 \mathrm{ft}$ in the eastern part of southwest Florida. Depth to the water table ranges from 1 to $20 \mathrm{ft}$. Water is withdrawn from the surficial aquifer by wells pumped for small volume uses such as domestic supply.

\section{Aquifer Recharge}

Recharge to the Floridan and minor artesian aquifers is by direct infiltration where confining beds are discontinuous or absent, or by leakage through the confining beds. Direct infiltration occurs in the following areas: where the confining bed is absent between the surficial aquifer and the Floridan aquifer; where a sinkhole creates a direct interconnection between the two aquifers; where a river or stream flows in direct contact with the aquifer; or where there is a surface outcrop of the aquifer. The surficial aquifer is recharged directly by rainfall which percolates downward under the influence of gravity. 
Approximately 1.2 billion gallons of freshwater were used each day in southwest Florida during 1975 (Leach, 1977). This use may be categorized as follows:

\begin{tabular}{|c|c|c|c|}
\hline Category & $\frac{\text { Ground water }}{(\mathrm{Mga} 1 / \mathrm{d})}$ & $\frac{\text { Surface water }}{(\mathrm{Mgal} / \mathrm{d})}$ & $\frac{\text { Total }}{(\mathrm{Mgal} / \mathrm{d})}$ \\
\hline Rura1 & 90.5 & 2.2 & 92.8 \\
\hline Municipal & 136.3 & 76.5 & 212.8 \\
\hline Industrial & 390.9 & 10.2 & 400.9 \\
\hline Irrigation & 431.6 & 35.7 & 467.3 \\
\hline $\begin{array}{l}\text { Thermoelectric, } \\
\text { fresh } \\
\text { Thermoelectric, }\end{array}$ & 1.1 & 420.8 & 421.9 \\
\hline saline & 0 & 5,414 & 5,414 \\
\hline Total & $1,049.3$ & $5,959.2$ & $7,009.6$ \\
\hline
\end{tabular}

These figures represent water-use totals for all counties either wholly or partly in the Southwest Florida Water Management District. About 90 percent of this water was from ground-water sources, while 10 percent was obtained from streams. Figure 6 shows surface-water use by counties and figure 7 shows ground-water use by counties. Municipal supply is a use of major importance. Figure 8 shows the location of the major municipal well fields in southwest Florida. For a more detailed breakdown of municipal water use see Healy (1977). Permits were issued for the drilling of more than 3,000 wells in the Southwest Florida Water Management District in 1976, including 2,275 domestic we11s, 131 industrial wells, 500 irrigation wells, and 109 municipal wells.

\section{HYDROLOGIC CONDITIONS}

The 12-month rainfa11 amount in $1976-77$ was less than the 1956-1975 average throughout southwest Florida by as much as 14 in (figs. 9 and 10). The rainfall for July 1976 to June 1977 ranged between about 32 in in the middle Withlacoochee River basin and about 44 in in the upper Peace River basin. The 20-year average rainfall was 56 in and 52 in for the two areas. A detailed description of rainfall in southwest Florida is given in a report entitled "Annual Rainfall Report, Water Year 1976-1977" by Jim Whalen, Southwest Florida Water Management District, Hydrometeorological Report No. 2, November 1977. 


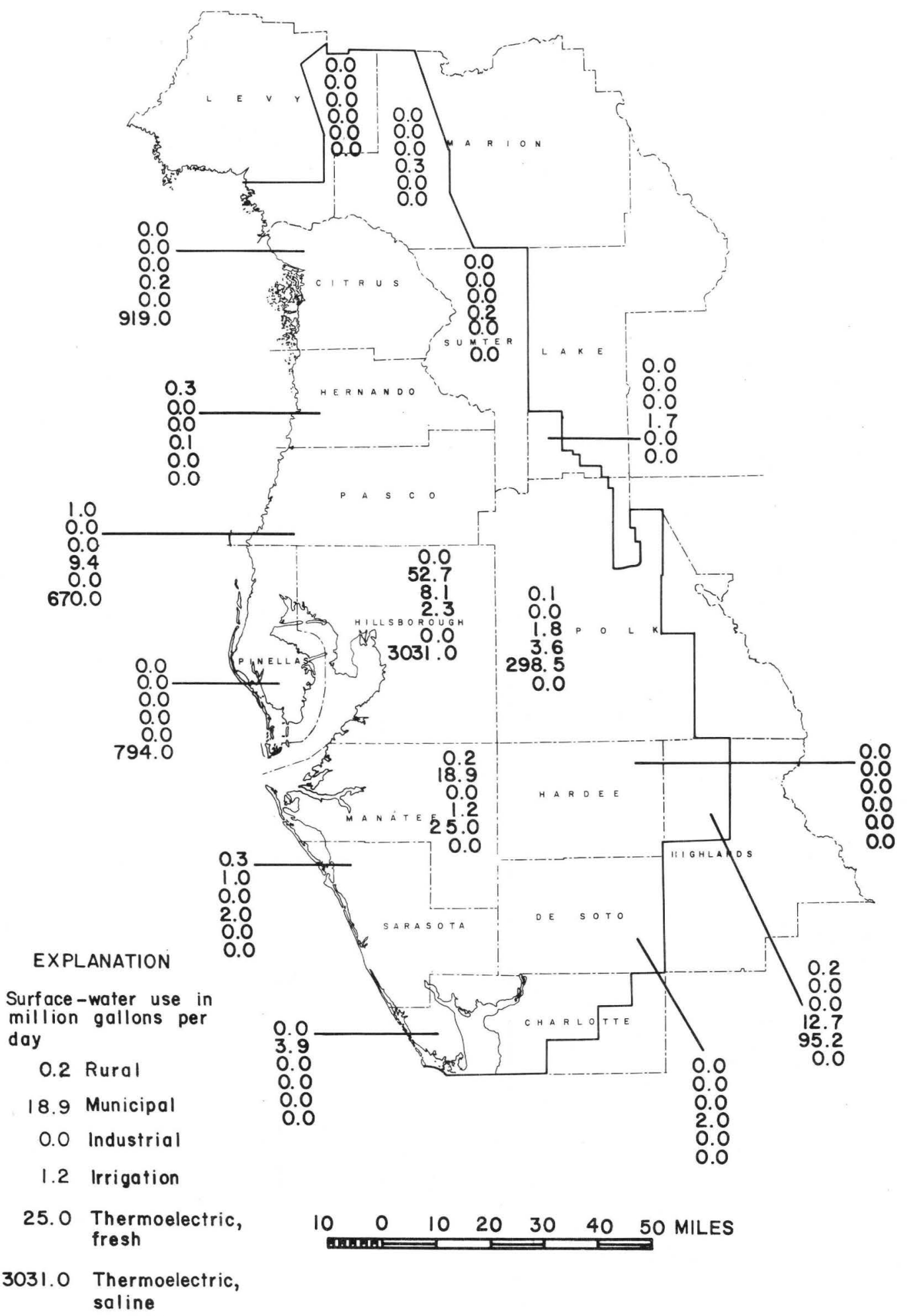

Figure 6. Surface-water use in southwest Florida, 1975. 


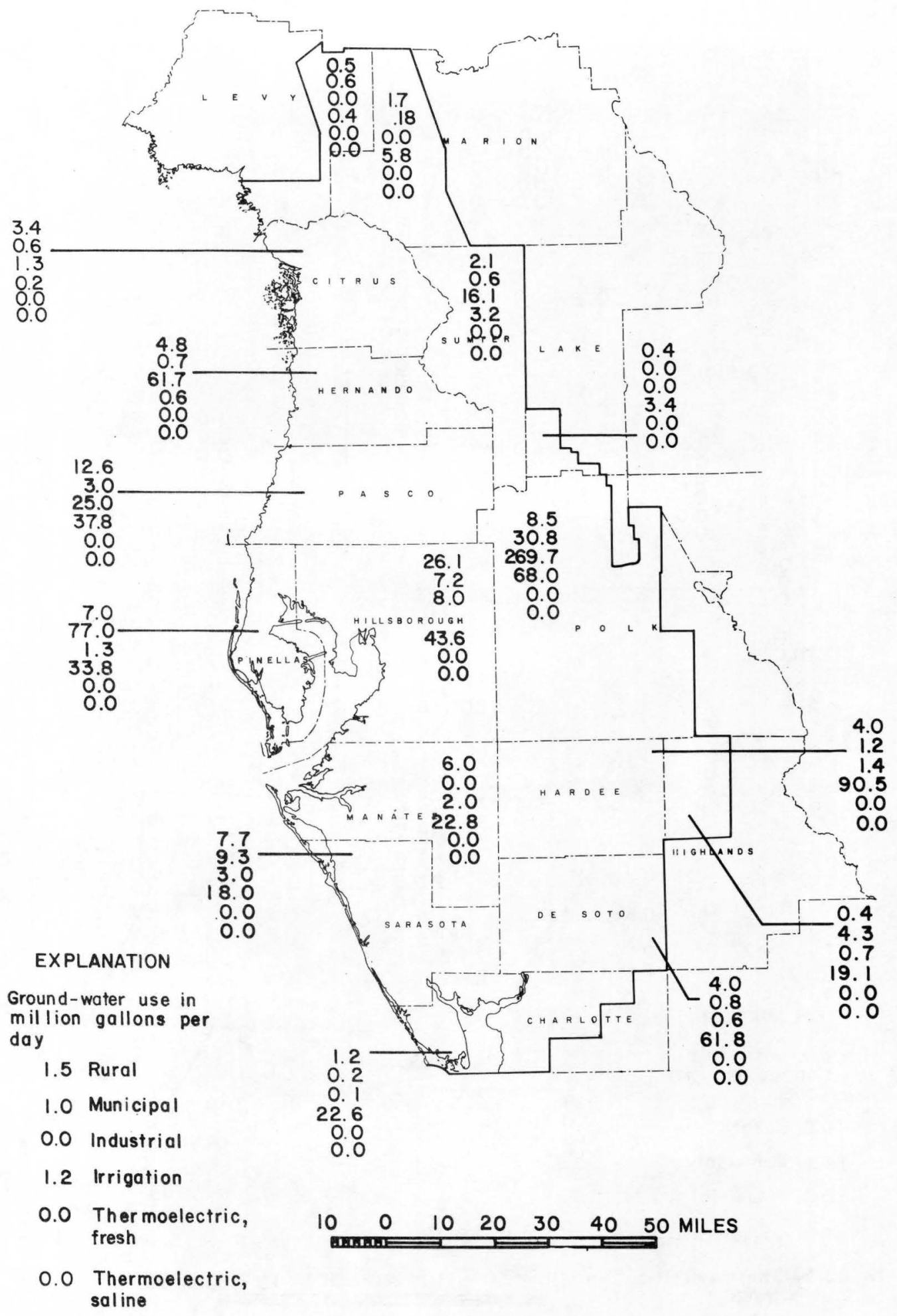

Figure 7. Ground-water use in southwest Florida, 1975. 
WELL FIELDS

1. Cypress Creek

2. Starkey

3. Eldridge-WIIde

4. Pasco

5. East Lake

6. Cosme

7. Section 21

8. Morris Bridge

9. Riverview

10. Sun Clity

Il. Verna

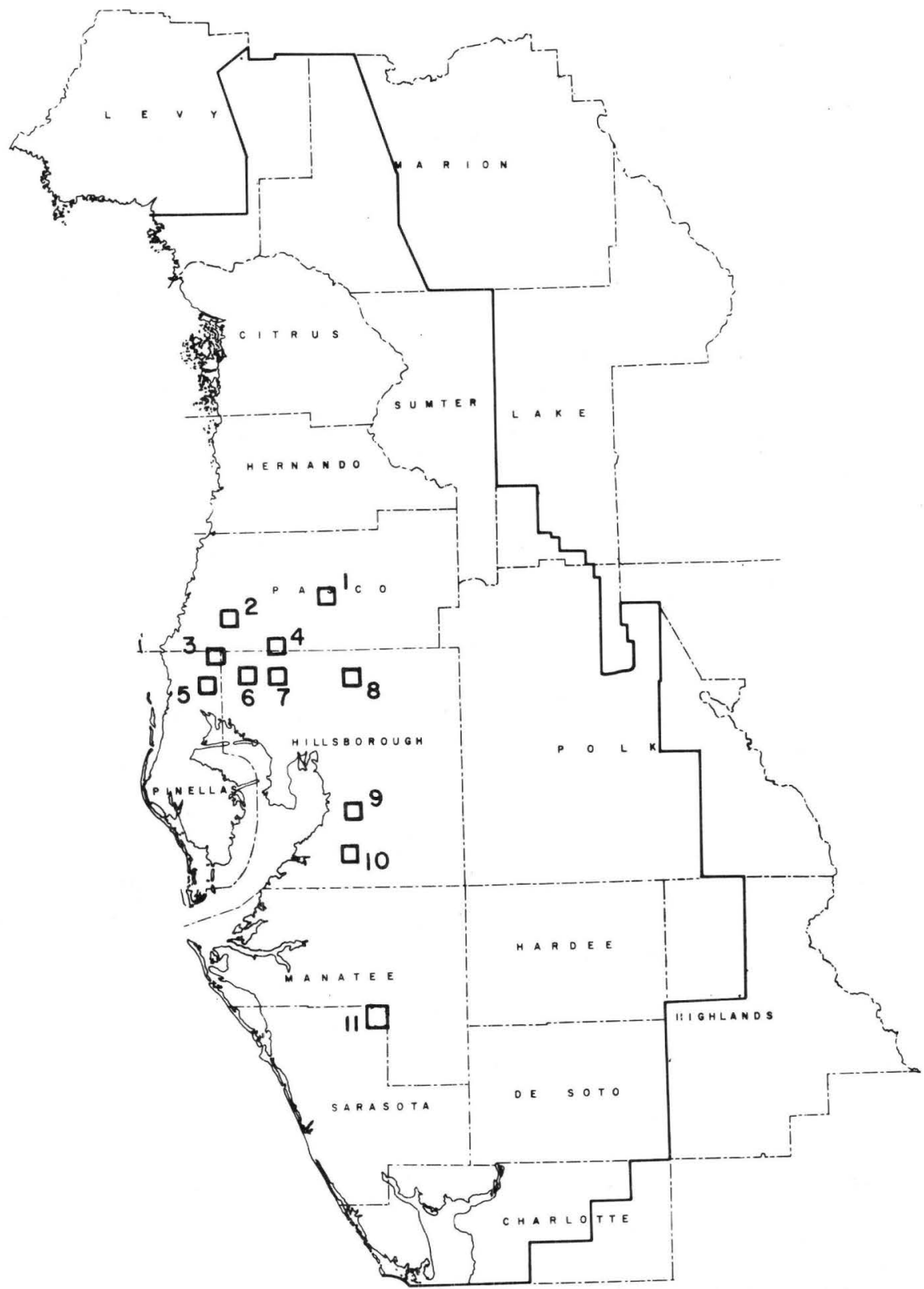

$10 \quad 0 \quad 10 \quad 20 \quad 30 \quad 40 \quad 50$ MILES

Figure 8. Location of the major municipal well fields in southwest Florida. 


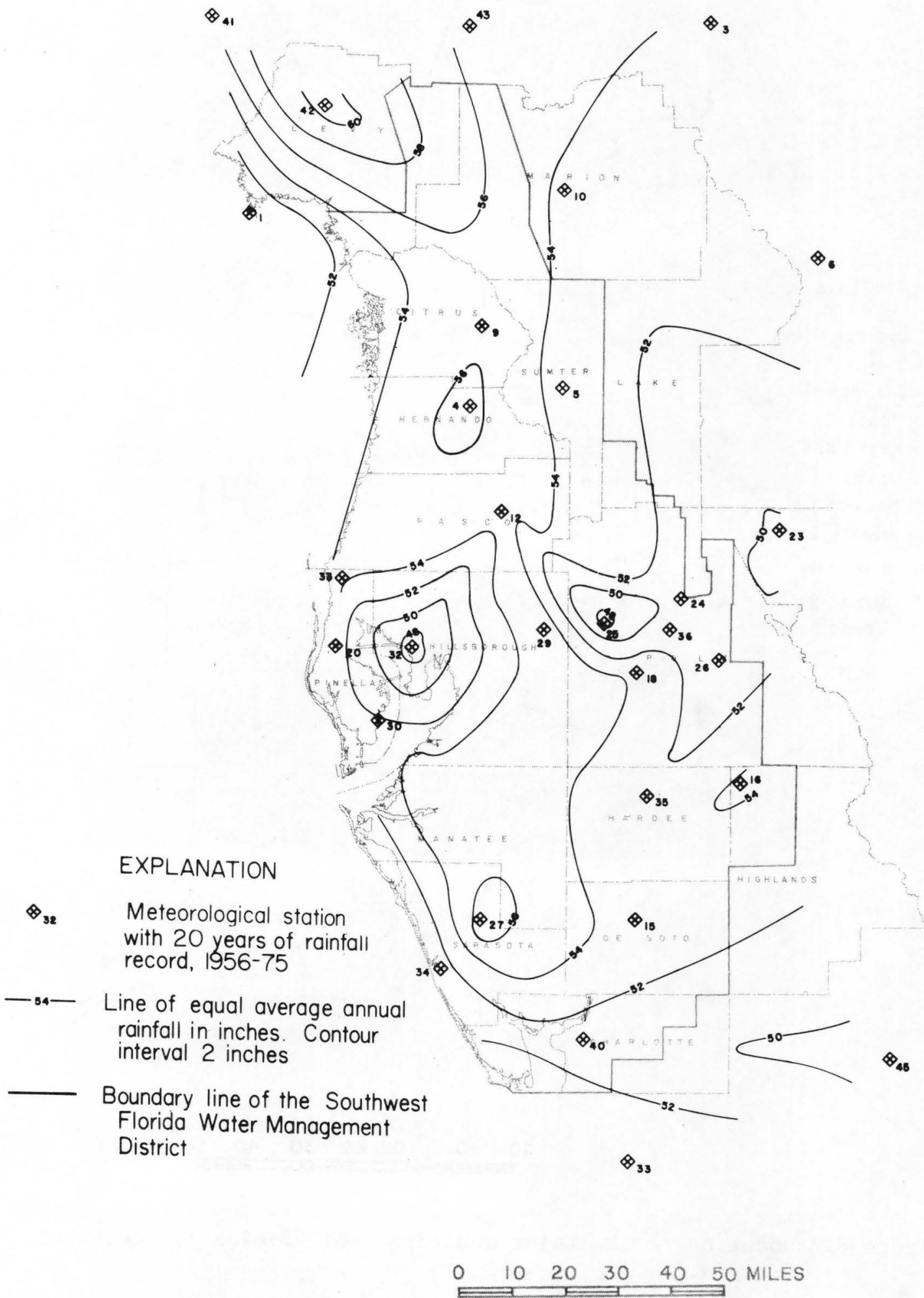

Figure 9. Rainfall map of southwest Florida, 1956-75. 


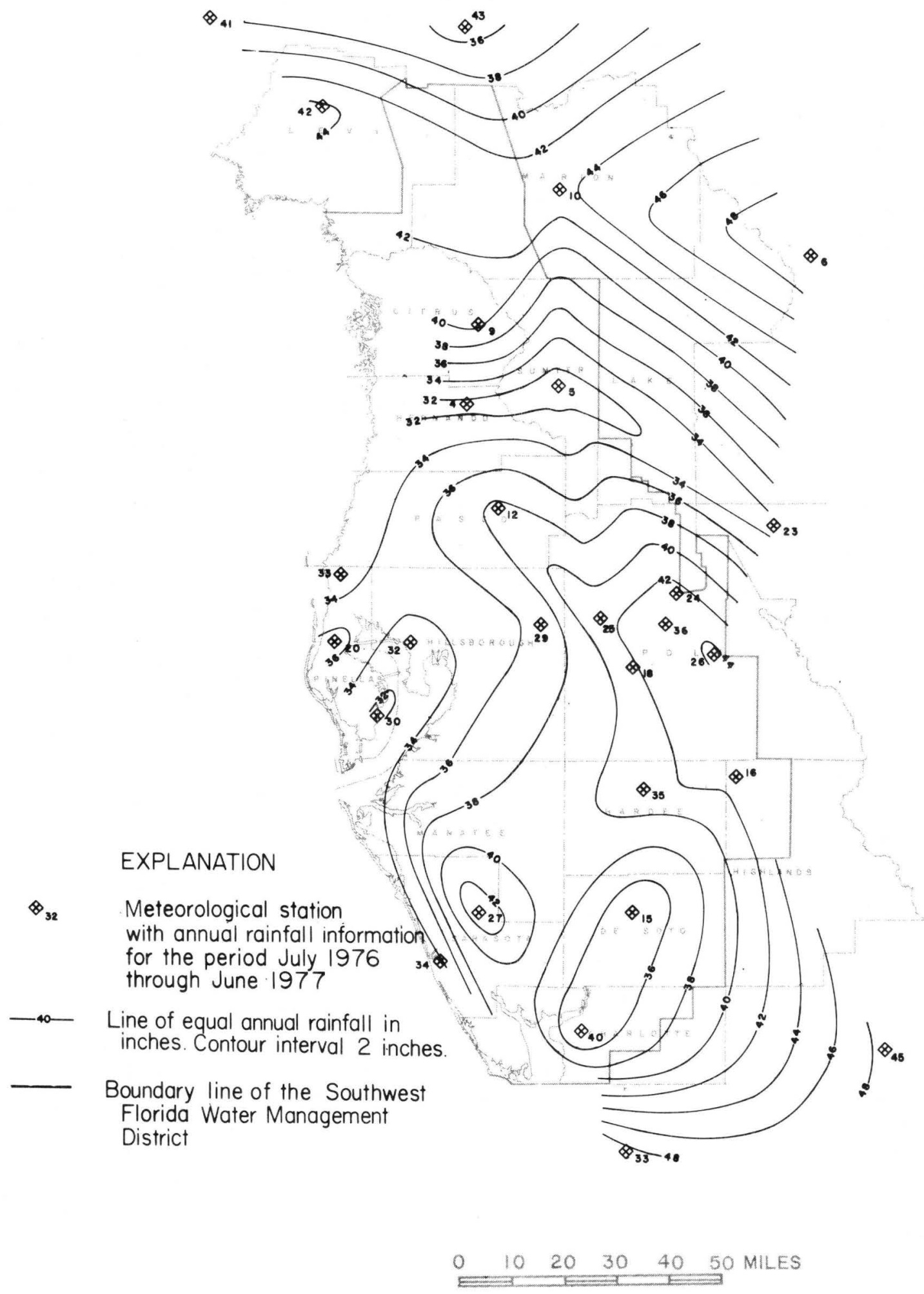

Figure 10. Rainfall map of southwest Florida, July 1976-June 1977. 
Streamflow during October 1976 to September 1977 was less than normal at all gaging stations selected for inclusion in this report to represent characteristics of runoff for southwest Florida. Streamflow at all of these sites was less than 50 percent of the long-term average, except for Myakka River near Sarasota which had a 1977 discharge of more than three-fourths of the long-term average.

Lake elevations for the year were generally below long-term averages. Lake Carroll in the Hillsborough River basin was 1 to $2 \mathrm{ft}$ below average for 1977, reaching a record 1ow in Ju1y 1977. Lake Howard in the Upper Peace River basin was 0.5 to $2 \mathrm{ft}$ below average for 1977, reaching a record low in June 1977. Crooked Lake, located along the highland ridge in southern Polk County, was 4 to $6 \mathrm{ft}$ below average for 1977, and was below the previous historical monthly low levels for the entire year.

The potentiometric surface of the Floridan aquifer, as measured at selected wells in the southern part of southwest Florida, declined as usual during the dry season (May). Recoveries in the autumn of 1977 indicated that the year-end levels were essentially the same as in 1976. In the northern part of the area, water-level fluctuations were essentially stable for the entire year.

\section{Surface Water}

For purposes of discussing surface-water conditions, southwest Florida is divided into three major areas: the Peace River Basin, the Withlacoochee River Basin, and coastal areas (fig. 5).

\section{Streams}

A network of 58 continuous streamflow sites and 77 periodic stage or discharge measurement sites is operated by the U.S. Geological Survey in southwest Florida (fig. 11). These data are used to provide background information on flow characteristics of rivers. Long-term hydrographs of monthly mean discharge for representative streamflow stations in the area are presented in the following discussion. The location of these stations are shown on figure 12 .

\section{Peace River Basin}

Discharge of the Peace Riyer at Arcadia for October 1976 to September 1977 (fig. 13) averaged $441 \mathrm{ft}^{3} / \mathrm{s}, 38$ percent of the long-term average. Streamflow was within 25 percent of normal for May to September 1977. Discharge of the Peace River at Bartow averaged $71.3 \mathrm{ft}^{3} / \mathrm{s}$ for October 


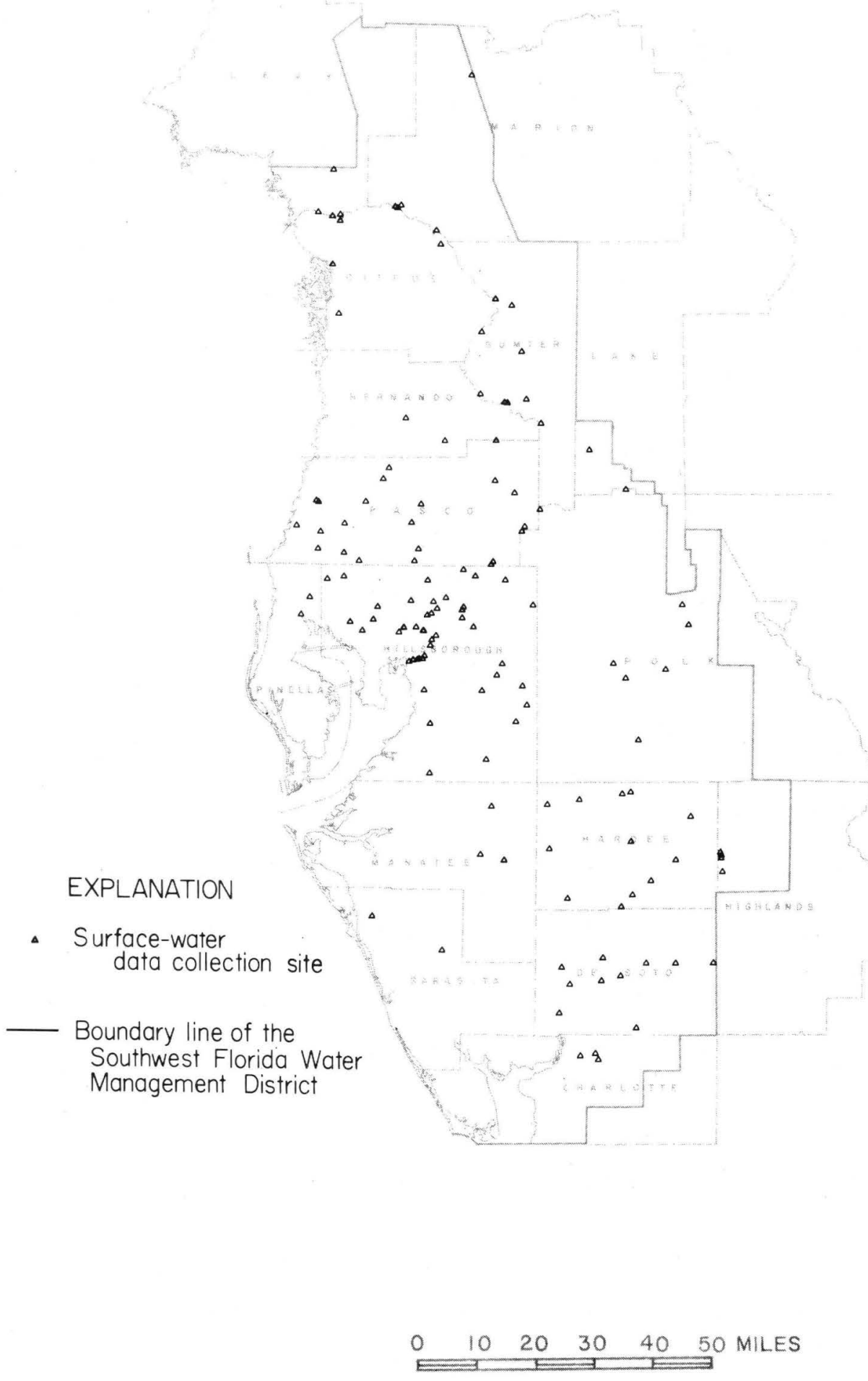

Figure 11. U.S. Geological Survey streamflow network in southwest Florida. 
1. Peace River at Arcadia

2. Peace River at Bartow

3. Withlacoochee River nr Holder

4. Withlacoochee River at Trilby

5. Myakka River $n r$ Sarasota

6. Little Manatee River nr Wimauma

7. Alafia River at Lithia

8. Hillsborough River $n r$ Zephyrhilis

9. Brooker Creek nr Tarpon Springs

10. Anclote River $\mathrm{nr}$ Elfers

11. Pithlachascotee River nr New Port Richey
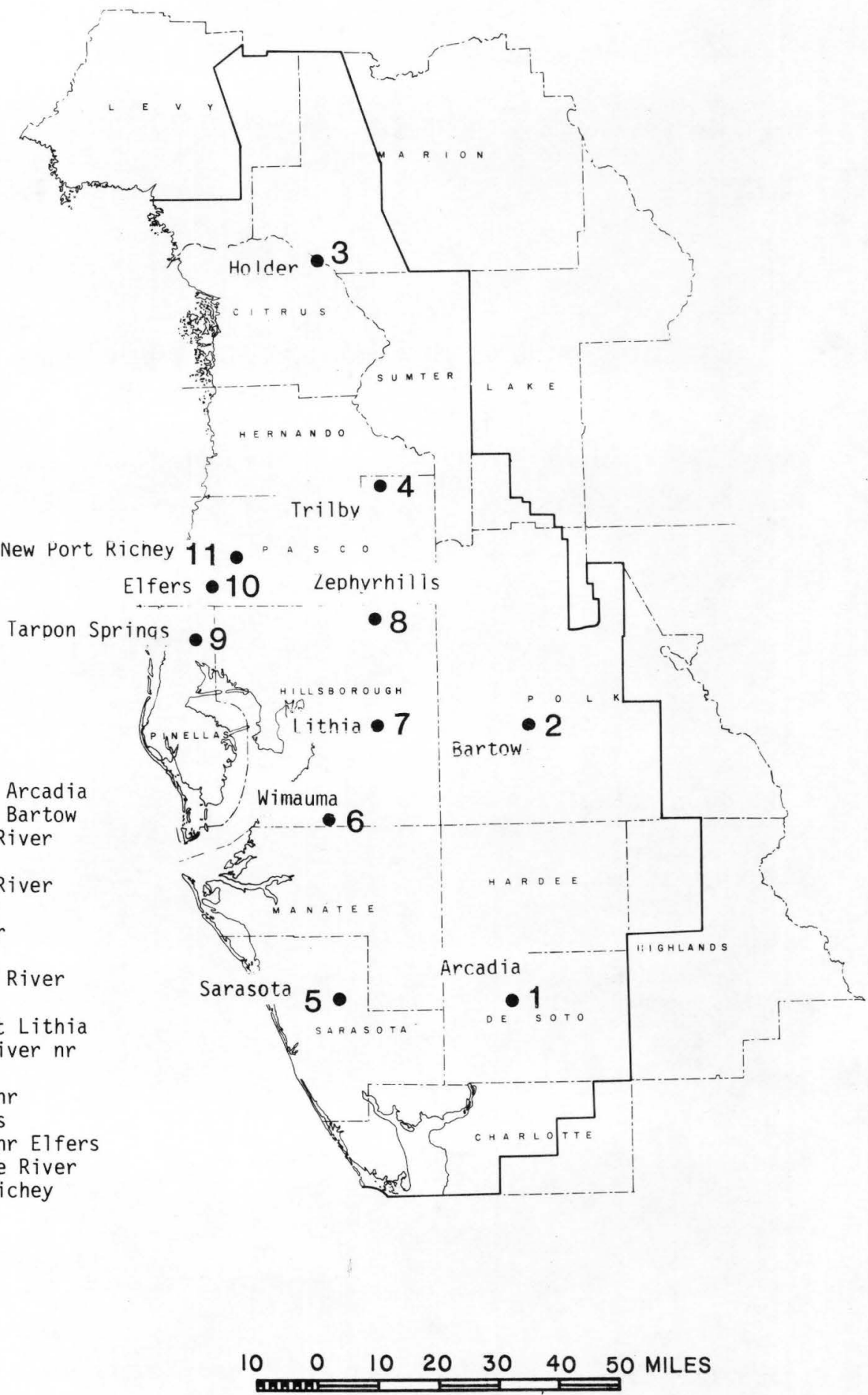

Figure 12. Location of streamflow stations for which hydrographs are presented in this report. 
1976 to September 1977, about 28 percent of the 1ong-term average. Most of the annual flow deficiency occurred from October 1976 to March 1977.

Withlacoochee River Basin

Discharge of the Withlacoochee River at Holder (fig. 14) averaged $550 \mathrm{ft}^{3} / \mathrm{s}$, about 50 percent of the long-term average. Runoff from the upper part of the başin, as shown by Withlacoochee River near Trilby (fig. 14), was $86 \mathrm{ft} / \mathrm{s}$, about 24 percent of the average flow. Most of the streamflow deficiency occurred in the upper basin.

Coastal and Other Areas

3 Runoff from the Myakka River near Sarasota (fig. 15) averaged 198 $\mathrm{ft}^{3} / \mathrm{s}, 78$ percent of the long-term average flow. This is the only site in the streamflow network where the 1977 average streamflow exceeded 50 percent of the historical average.

Discharge of Little Manatee River (fig. 15) near Wimauma averaged 39 percent of the long-term average. During March, April, and May, the monthly mean flow was less than $60 \mathrm{ft}^{3} / \mathrm{s}$. The Alafia River, which has a high base flow because of numerous springs along the stream channel, averaged $142 \mathrm{ft}^{3} / \mathrm{s}, 39$ percent of the long-term average. Lithia Springs, one of the larger springs in the area, flows into the river about $2 \mathrm{mi}$ downstream from the gaging station.

Flow in the upper part of the Hillsborough River Basin is measurejd at the gaging station near Zephyrhills (fig. 16). It averaged $103 \mathrm{ft}^{3} / \mathrm{s}$, 39 percent of the long-term average. Runoff from swamps and lakes in the Tampa Bay area is measured at the gaging station Brooker Creek near Tarpon Springs (fig. 17). At that station, the long-term average flow was 5.3 $\mathrm{ft}^{3} / \mathrm{s}$.

Runoff from the wooded flatlands immediately north of Tampa Bay is represented by the Anclote River near Elfers (fig. 17) where the discharge averaged $16.5 \mathrm{ft}^{3} / \mathrm{s}$, about 14 percent of the long-term average.

The Pithlachascotee River, draining an area of swamps and sinkholes in the coastal plains, typifies the flow that is characteristic of the northern part of the District. The Pithlachasçotee River near New Port Richey (fig. 18) had an average flow of $8.7 \mathrm{ft} / \mathrm{s}$, about 28 percent of average flow.

Most of the flow in the coastal streams in the northern part of the area comes from a series of springs and spring clusters. The principal springs are Weeki Wachee and Chassahowitzka in western Hernando County and Homossassa and Crystal in western Citrus County. A11 of these springs flow into the Gulf of Mexico. 

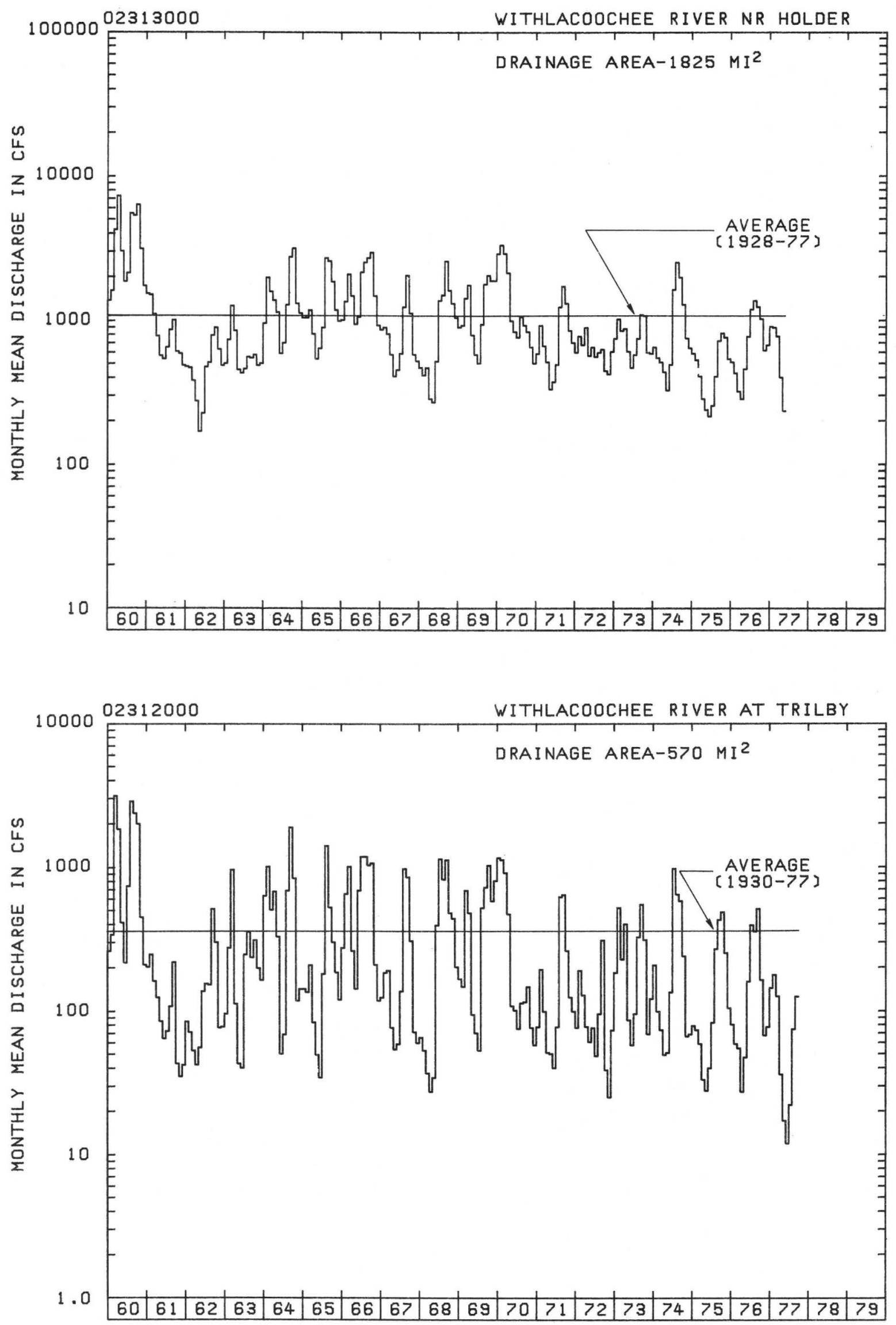

Figure 14. Hydrographs of streamflow for the Withlacoochee River near Holder and at Trilby. 

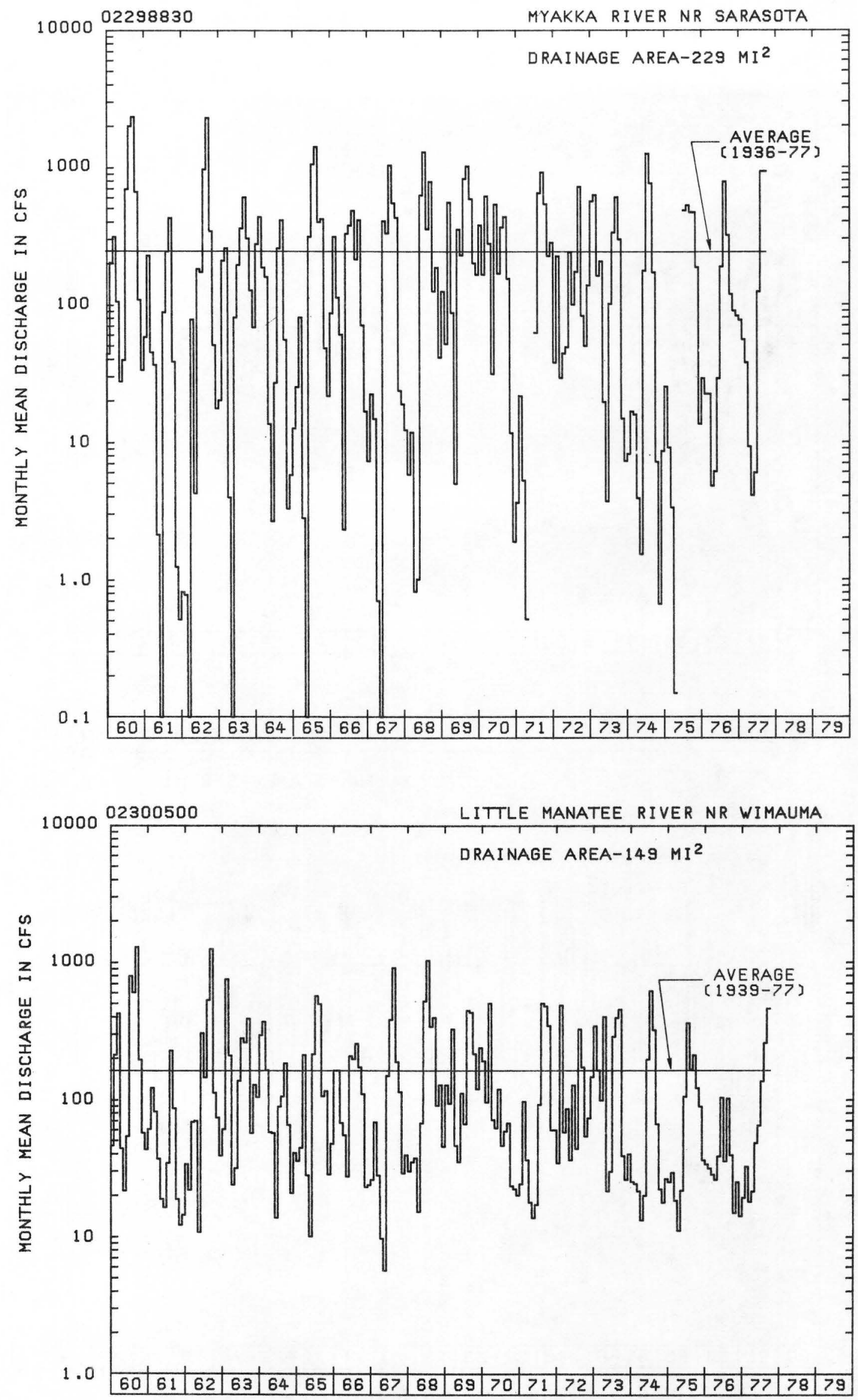

Figure 15. Hydrographs of streamflow for the Myakka River near Sarasota and the Little Manatee River near Wimauma. 

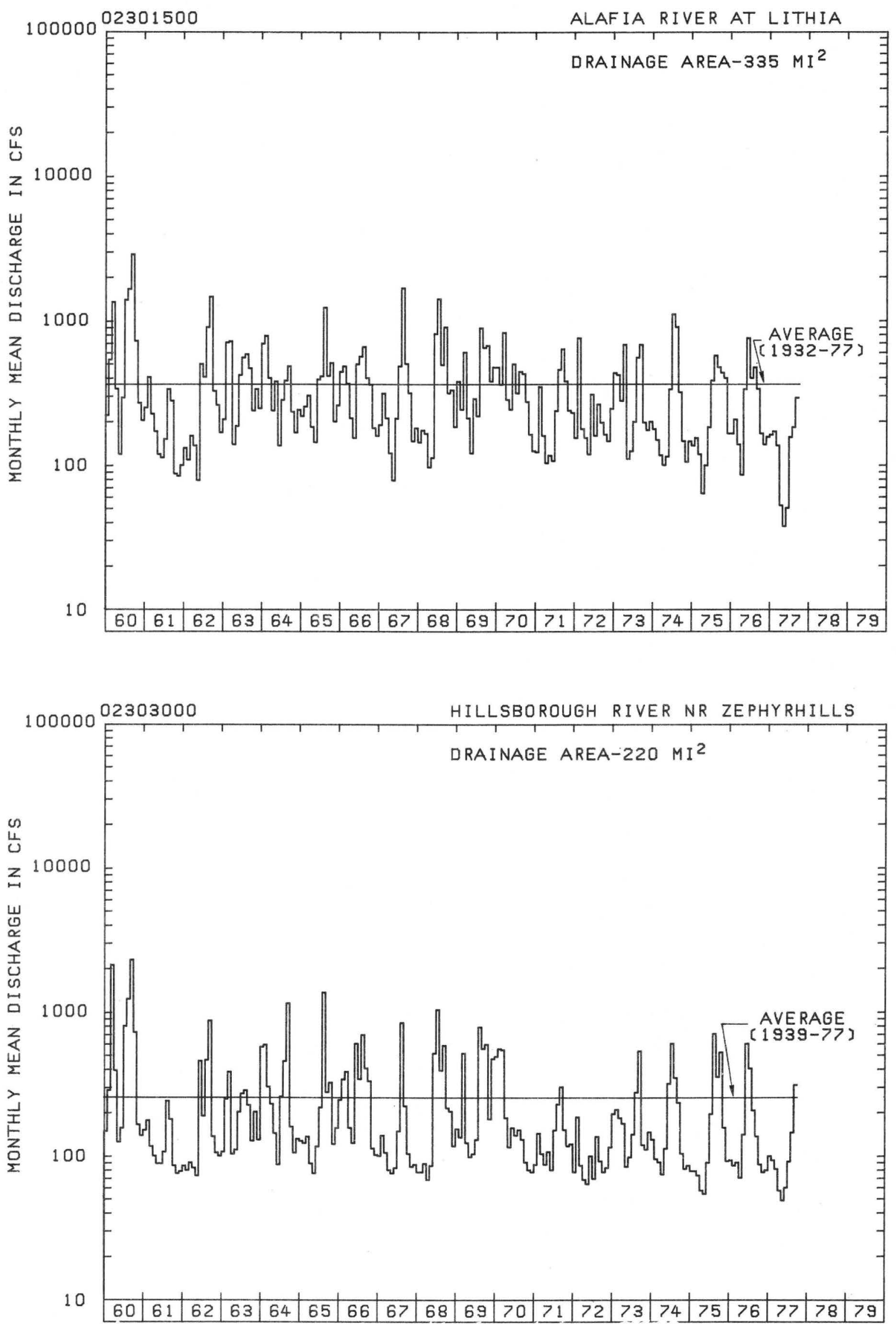

Figure 16. Hydrographs of streamflow for the Alafia River at Lithia and the Hillsborough River near Zephyrhills. 

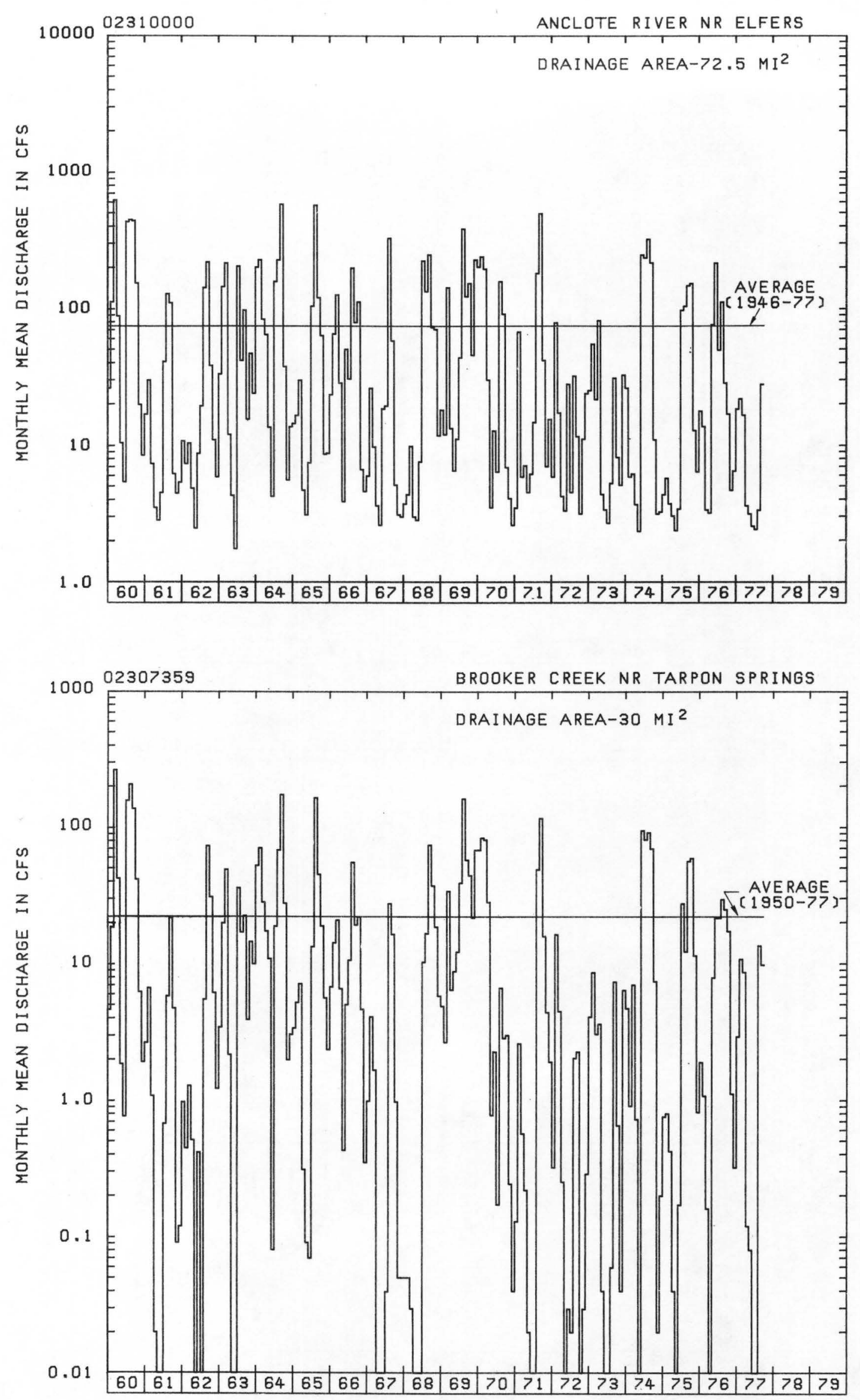

Figure 17. Hydrographs of streamflow for the Anclote River near Elfers and Brooker Creek near Tarpon Springs. 


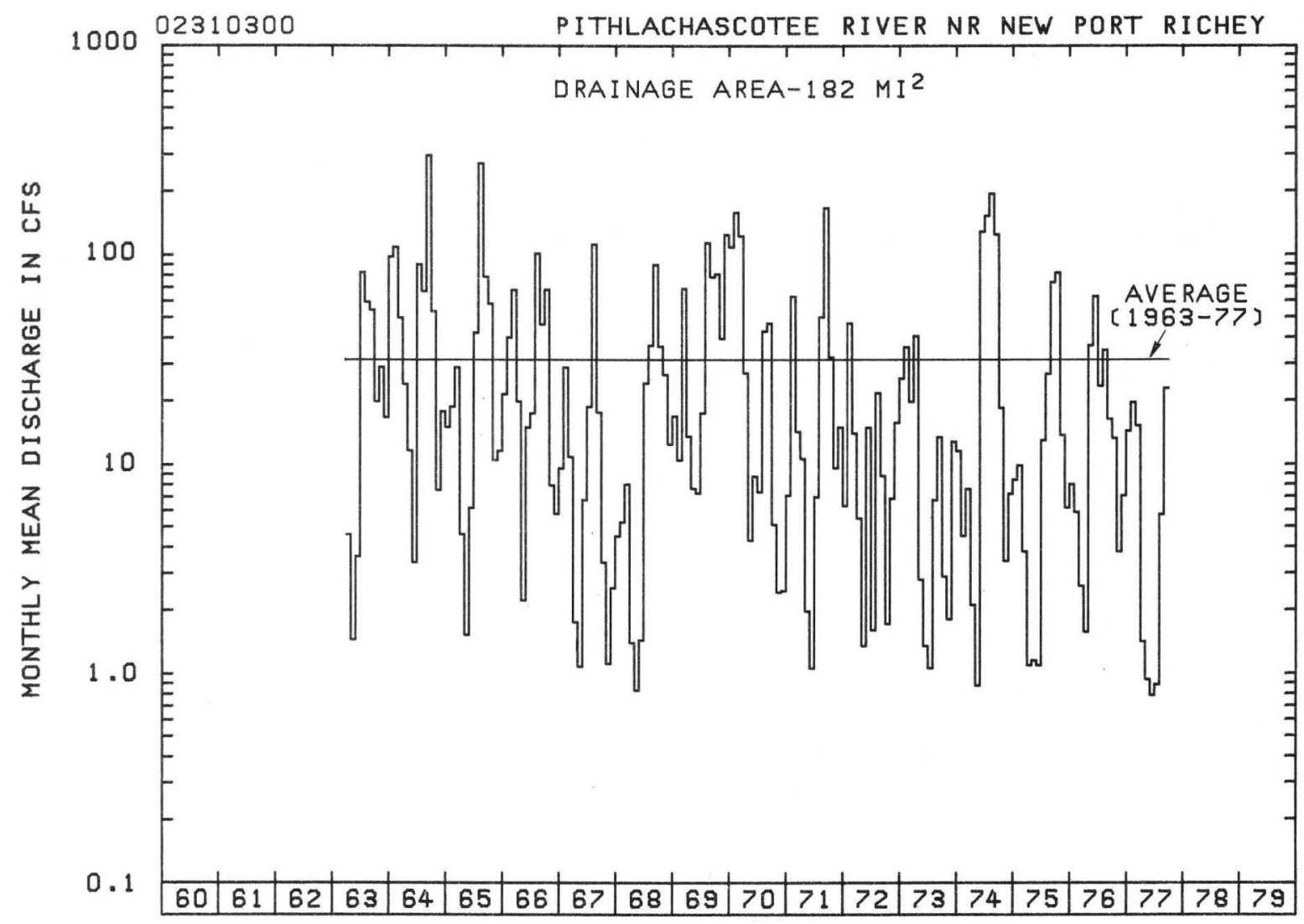

Figure 18. Hydrograph of stream flow for the Pithlachascotee River near New Port Richey. 
Lake levels in southwest Florida fluctuate in response to rainfall, ground-water inflow and outflow, evapotranspiration, surface-water inflow and outflow, and artificial input and withdrawal. A network of 124 lake stage measurement sites are operated by the U.S. Geological Survey in southwest Florida (fig. 19). Location of sites for which long-term hydrographs of month-end stage are presented in this report are shown on figure 20.

Lake Howard and Lake Hamilton

The levels of Lake Howard at Winter Haven (fig. 21), one of the principal lakes in the Winter Haven Chain of Lakes, was between 1 and $2 \mathrm{ft}$ below average for most of the year. Levels remained within $1 \mathrm{ft}$ of minimum for most of the year, exceeding the minimum end-of-month level by only $0.1 \mathrm{ft}$ for June. The level of Lake Hamilton (fig. 21) rose slightly from July to September, but was still below average at the end of the year. The level of Lake Hamilton fluctuated during the year similar to that of Lake Howard. The levels of both lakes are maintained by artificial control structures.

\section{Lake Otis and Crooked Lake}

The seasonal fluctuations of the level of Lake Otis (fig. 22) at Winter Haven during 1977 were the same as the fluctuations in the previous year. In recent years, declines in both lake stage and the potentiometric surface of the Floridan aquifer were similar. The stage of Crooked Lake near Babson Park (fig. 22) also declined during the year and at year end, the stage was below the previous year.

\section{Lake Thonotosassa}

The lake level of Lake Thonotosassa (fig. 23) is maintained by an artificial control in Flint Creek, a tributary to the Hillsborough River. The stage was alternately lowered and raised in 1975 to improve flushing of the lake. The lake stage was lowered to $34.9 \mathrm{ft}$ in the spring and raised to $37.0 \mathrm{ft}$ in autumn, 1977.

\section{Lake Carroll}

The levels of Lake Carroll (fig. 23) near Sulphur Springs, was between 1 and $2 \mathrm{ft}$ below average for almost the entire year. Although the level generally was below the 32-year average, the seasonal maximum and minimum lake levels have been approximately the same each year since 1970 . 


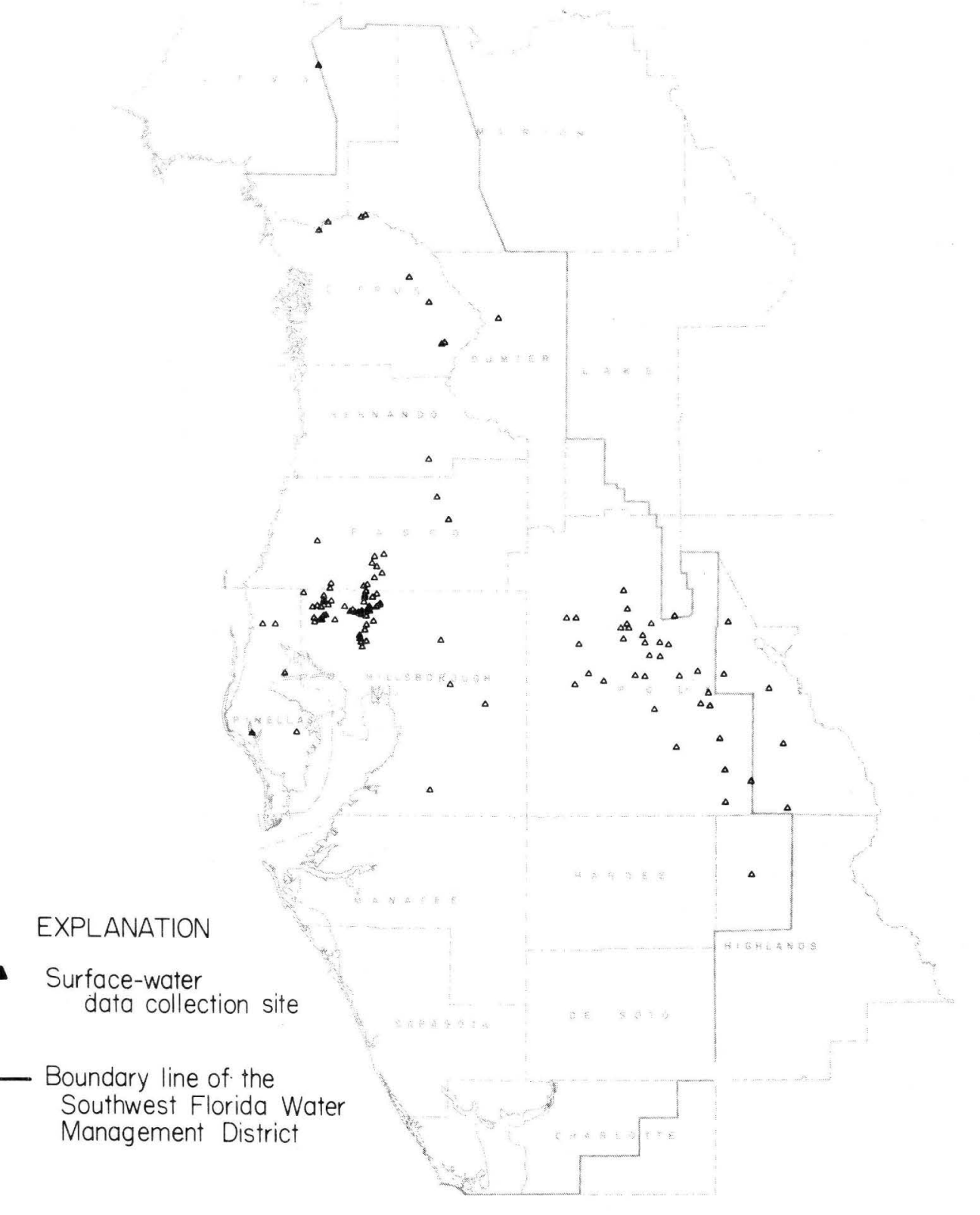

- Surface-water

data collection site

Boundary line of the

Southwest Florida Water

Management District

\begin{tabular}{rrrrr}
10 & 20 & 30 & 40 & 50 \\
\hline
\end{tabular}

Figure 19. U.S. Geological Survey lake-stage network in southwest Florida. 
1. Lake Howard at Winter Haven

2. Lake Hamilton $n r$ Lake Hamilton

3. Lake Otis at Winter Haven

4. Crooked Lake $n r$ Babson Park

5. Lake Thonotosassa at Thonotosassa

6. Lake Carroll nr Sulphur Springs

7. Lake Magdalene $n r$ Lutz

8. Keystone Lake $n r$ Odessa

9. Tsala-Apopka Lake at Inverness

10. Lake Panasoffkee $n r$ Lake Panasoffkee

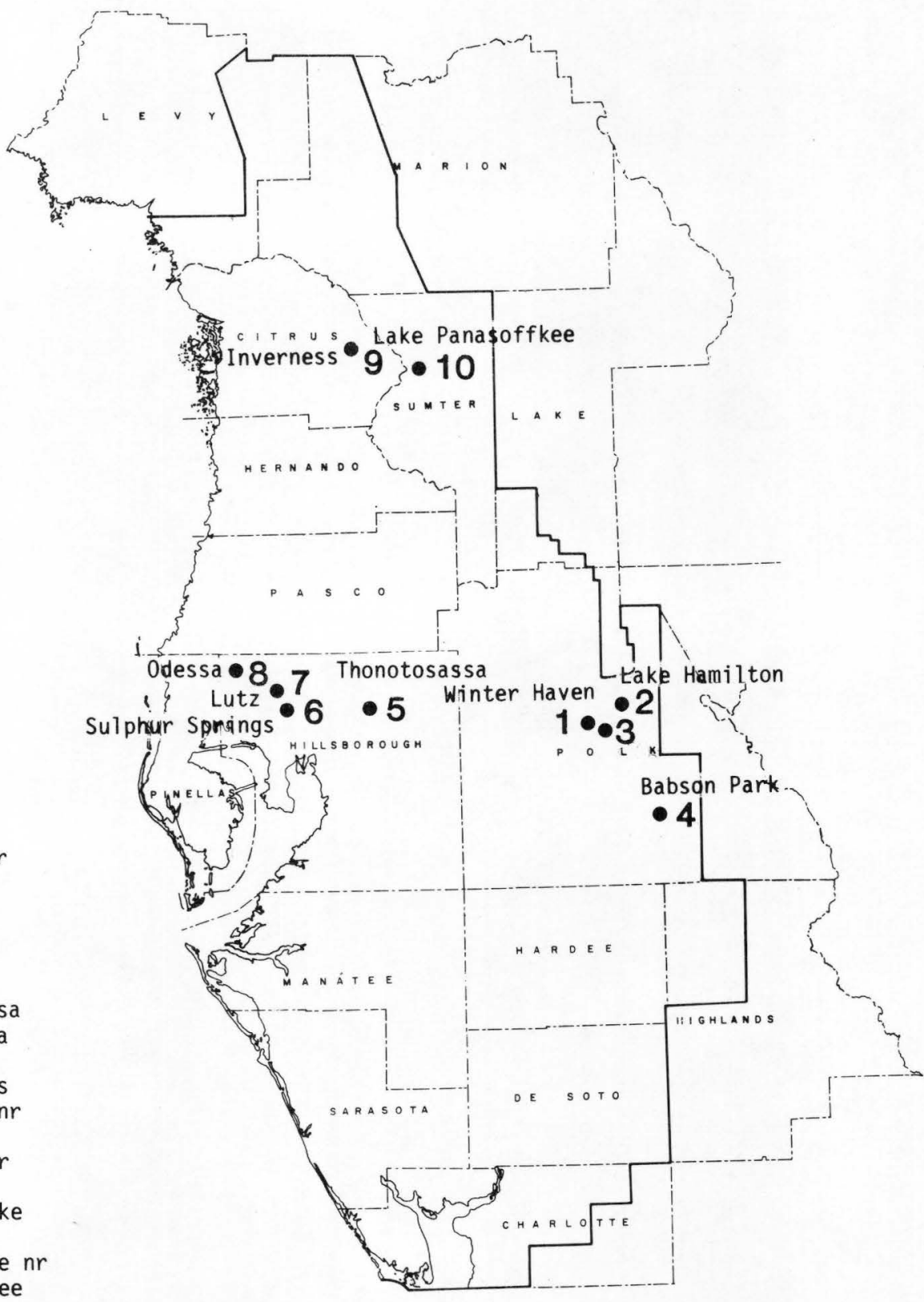

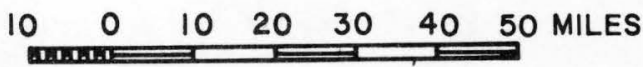

Figure 20. Location of lake stations for which hydrographs are presented in this report. 

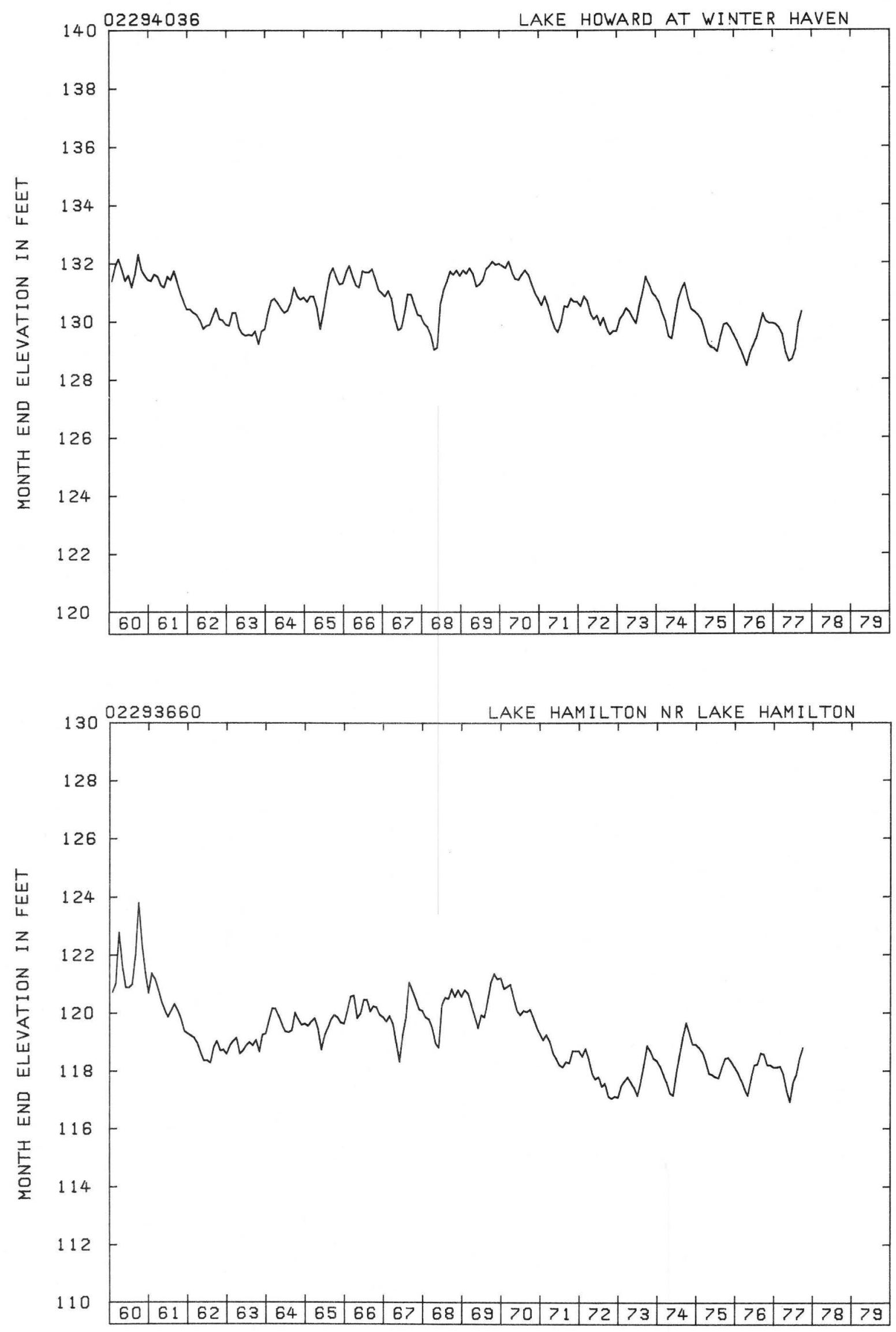

Figure 21. Hydrographs of lake stage for Lake Hamilton near Lake Hamilton and Lake Howard at Winter Haven. 

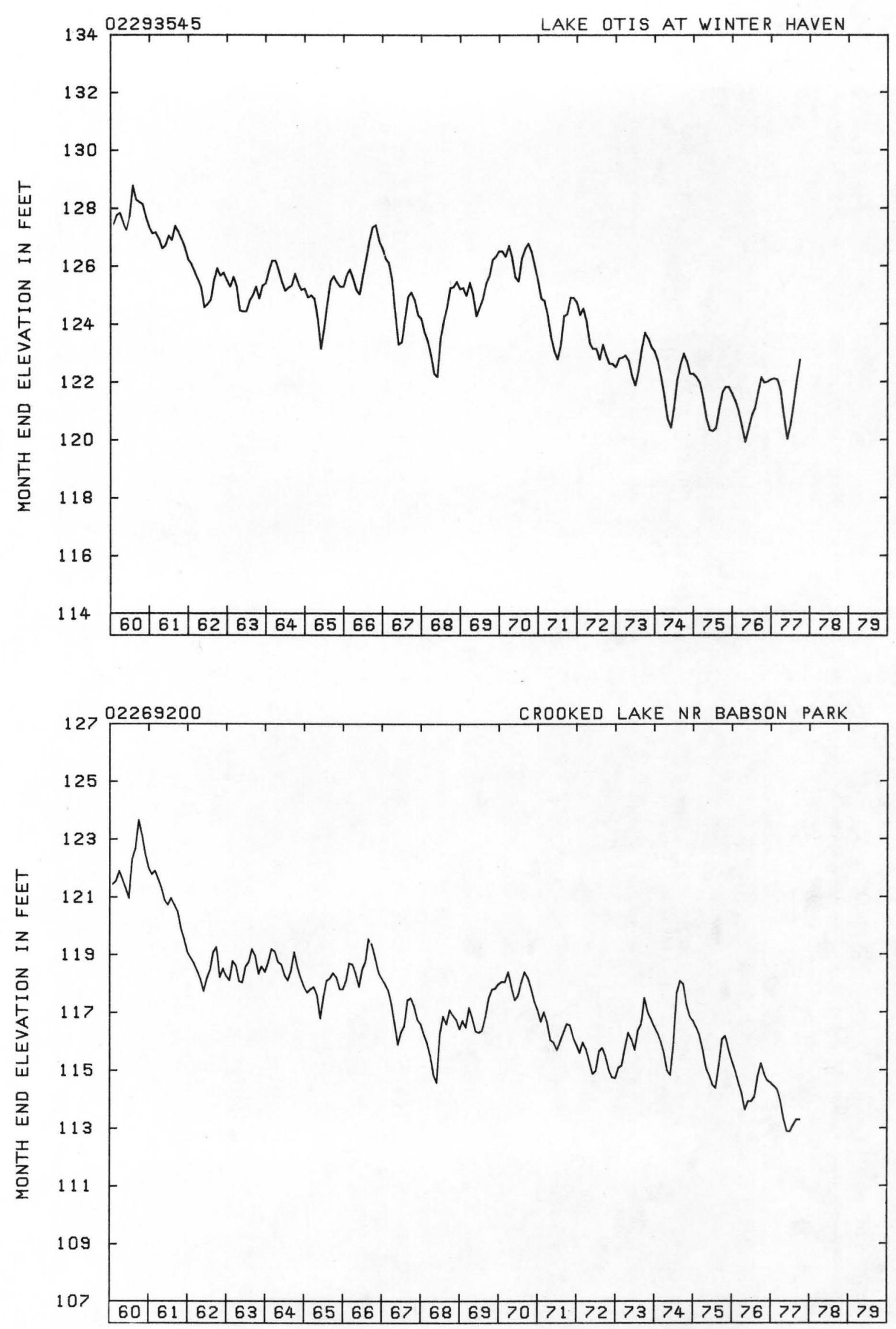

Figure 22. Hydrographs of lake stage for Lake Otis at Winter Haven and Crooked Lake near Babson Park. 

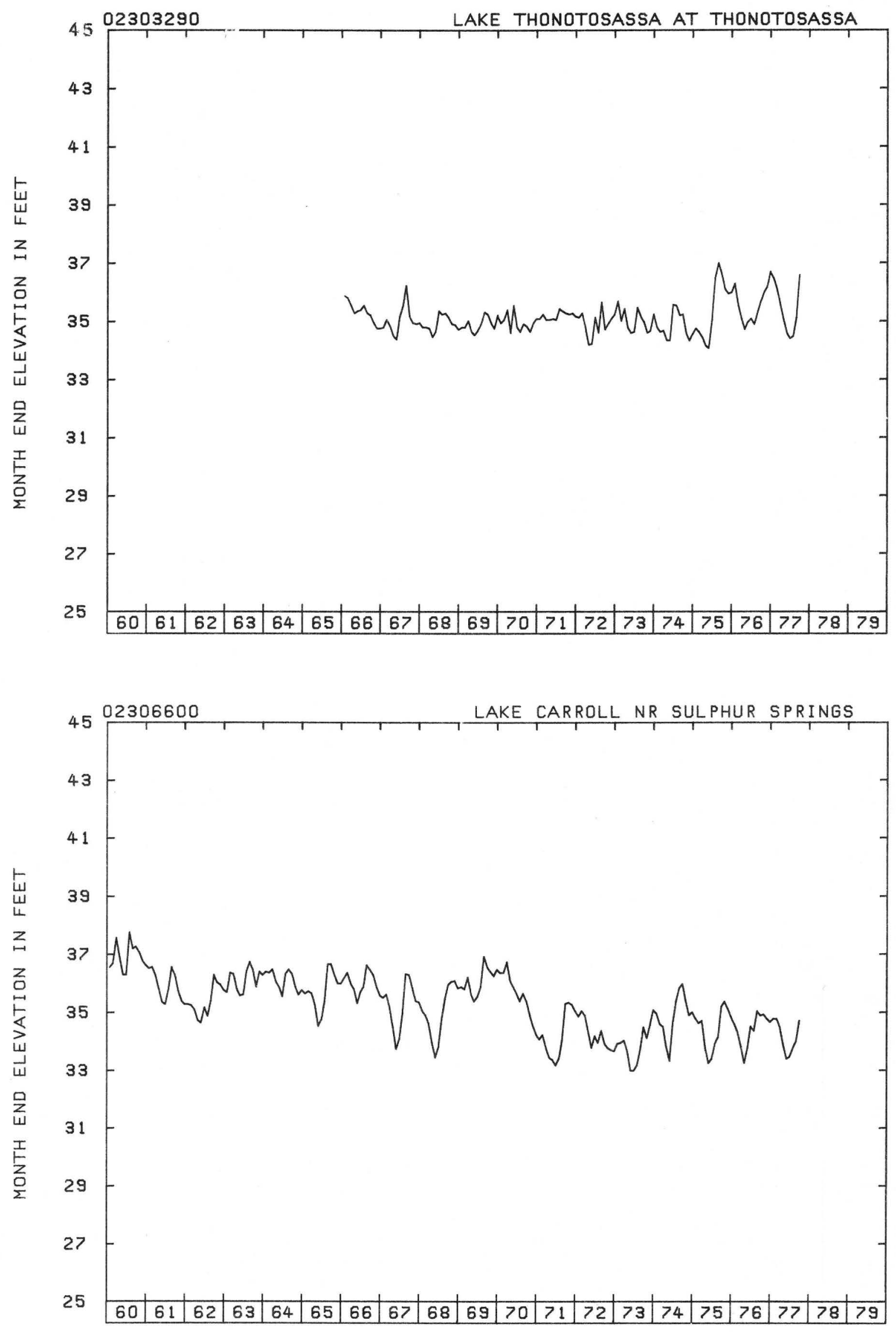

Figure 23. Hydrographs of lake stage for Lake Thonotosassa at Thonotosassa and Lake Carroll near Sulphur Springs. 
Lake Magdalene and Keystone Lake

Levels in Lake Magdalene (fig. 24) near Lutz and Keystone Lake near Lutz in northwest Hillsborough County, are maintained by artificial controls. The level of Lake Magdalene is generally held between 48 and 50 ft by a stop-log control. The level of Keystone Lake (fig. 24) generally varies between 39 and $42 \mathrm{ft}$. Keystone Lake declined to a level below 39 $\mathrm{ft}$ in 1977 for the first time in 4 years.

Lake Tsa1a-Apopka and Lake Panasoffkee

Lake Tsala-Apopka (fig. 25) at Inverness declined about 2 ft during the year, but the fluctuations are consistent with long-term trends for the lake. The stage of Lake Panasoffkee (fig. 25), tributary to the Withlacoochee River above Lake Tsala-Apopka, was between 39 and $41 \mathrm{ft}$ during the year. These stages represent a slight increase following a gradual decline during 1970-75.

\section{Ground Water}

Potentiometric surface and water-table levels in southwest Florida fluctuate in response to change in streamflow, lake levels, evapotranspiration, ground-water withdrawal, tides, and rainfall. A network of 1,200 periodic and 116 continuous ground-water measurement sites is operated by the U.S. Geological Survey in southwest Florida (fig. 26).

Potentiometric maps, representing water levels in the Floridan aquifer within the management district, are prepared twice each year. Measurements are made each May and September in more than 900 we11s. Figures 27,28 and 29 are examples of potentiometric maps (reduced from scale of 1:500,000) for September 1976, May 1977, and September 1977. During the period of September 1976 to May 1977, the potentiometric surface of the Floridan aquifer (fig. 28) declined as much as $30 \mathrm{ft}$ in Hillsborough, Hardee, and Manatee Counties. These areas are affected by withdrawal for irrigation. During the period of May to September 1977, the potentiometric surface recovered of 15 to 30 in these same areas (fig. 29).

Potentiometric and water-table maps are also prepared for 11 selected municipal well fields (fig. 8) in May and September (figs. 30, 31, 32, and 33). These maps define the effect of localized large scale ground-water withdrawals on the aquifer. From September 1976 to May 1977, declines in the potentiometric surface in the vicinity of the municipal well fields ranged from $3 \mathrm{ft}$ at the Starkey well field to $25 \mathrm{ft}$ at the Sun City well field (fig. 30). 

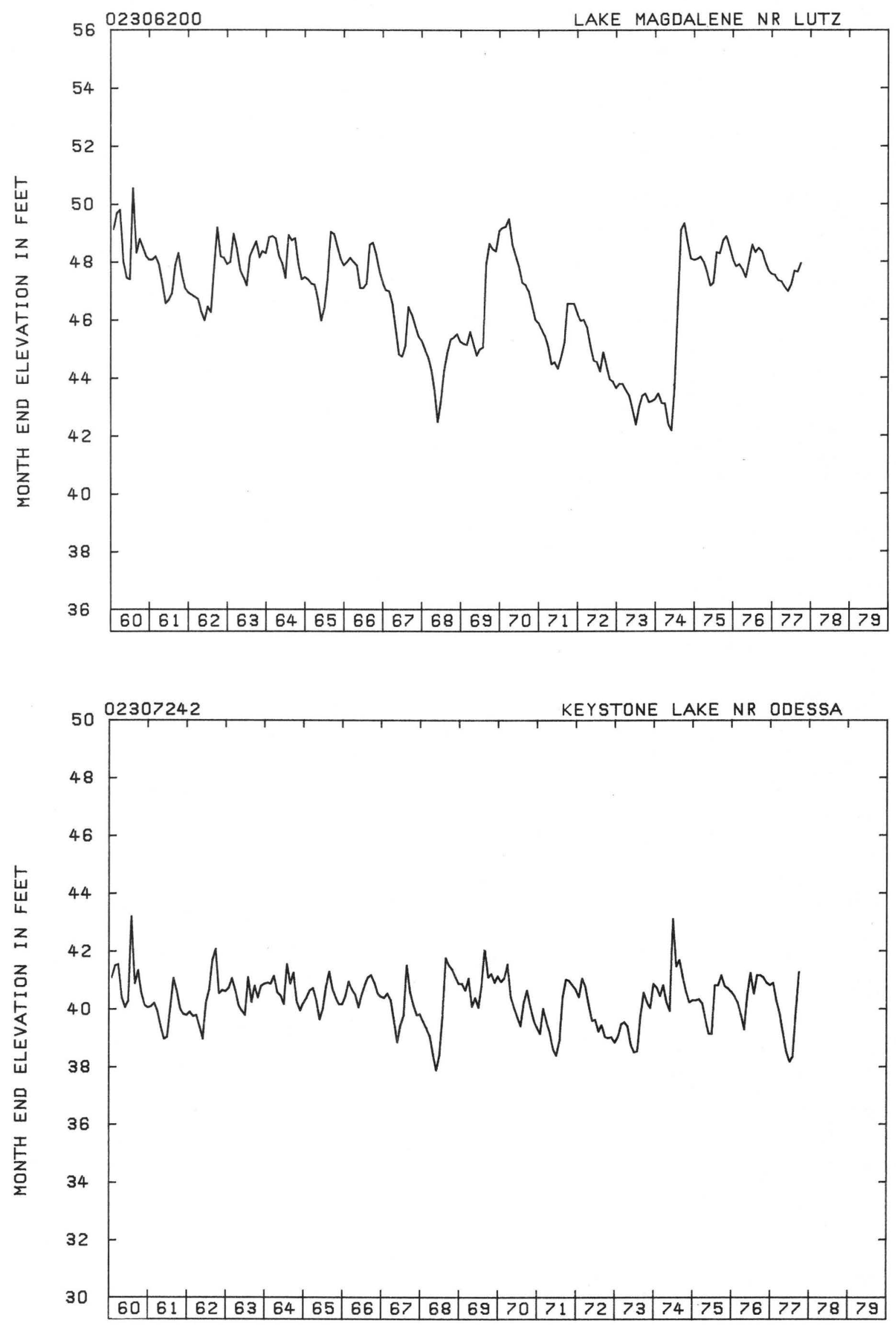

Figure 24. Hydrographs of lake stage for Lake Magdalene near Lutz and Keystone Lake near Odessa. 

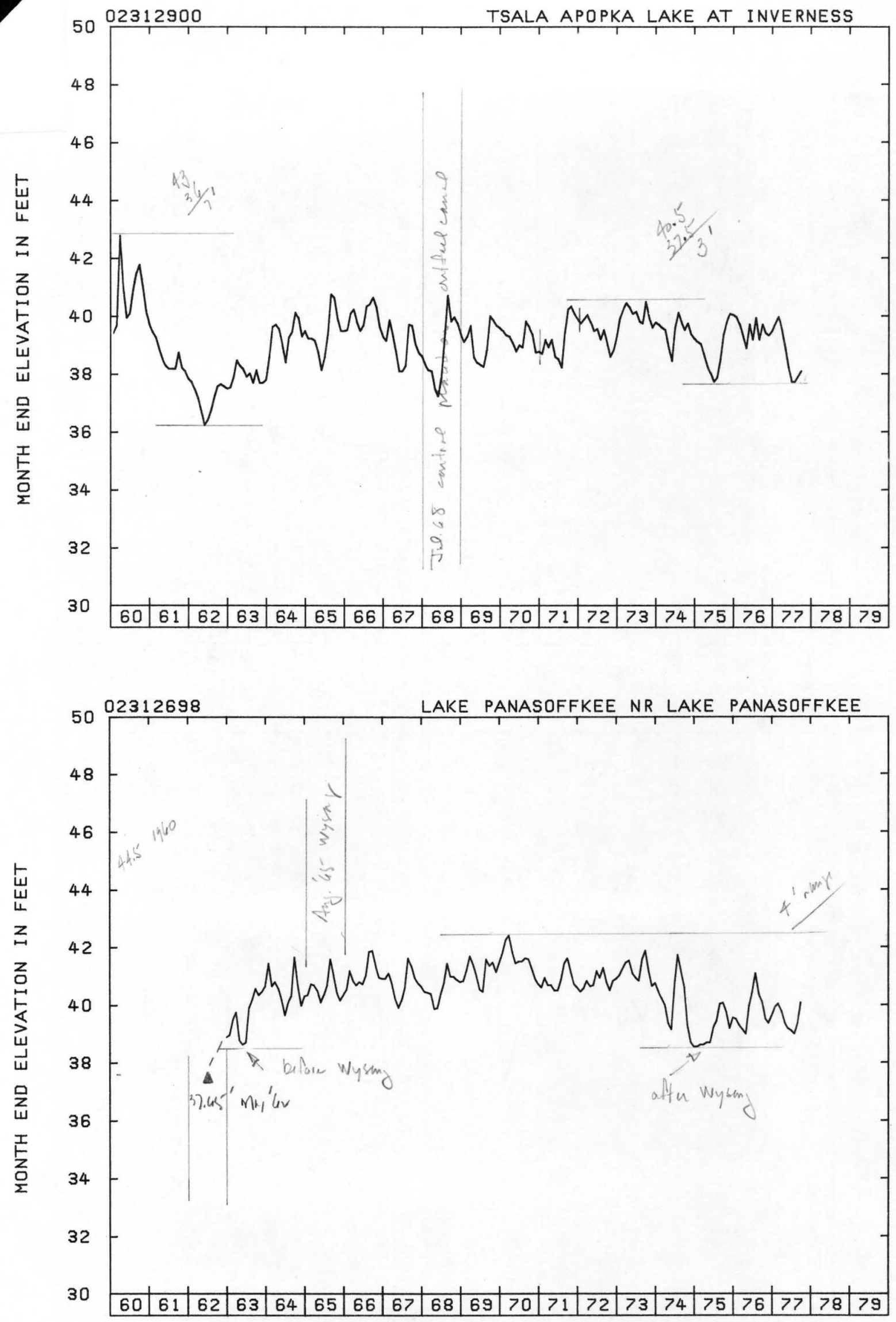

Figure 25. Hydrographs of lake stage for Lake Tsala-Apopka at Inverness and Lake Panasoffkee near Lake Panasoffkee. 


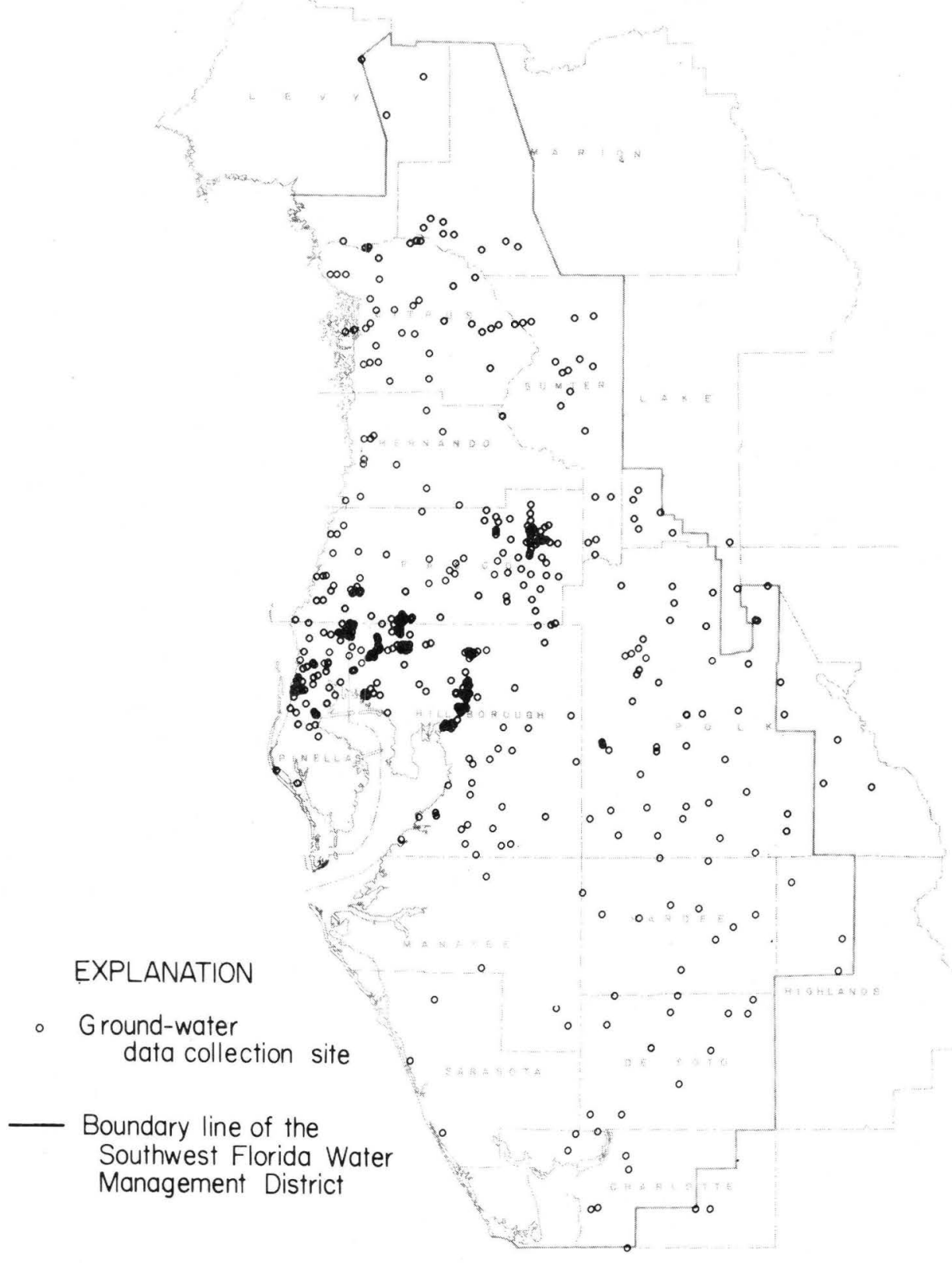

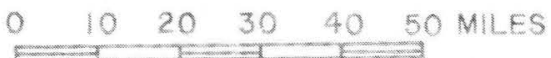

Figure 26. U.S. Geological Survey ground-water network in southwest Florida. 


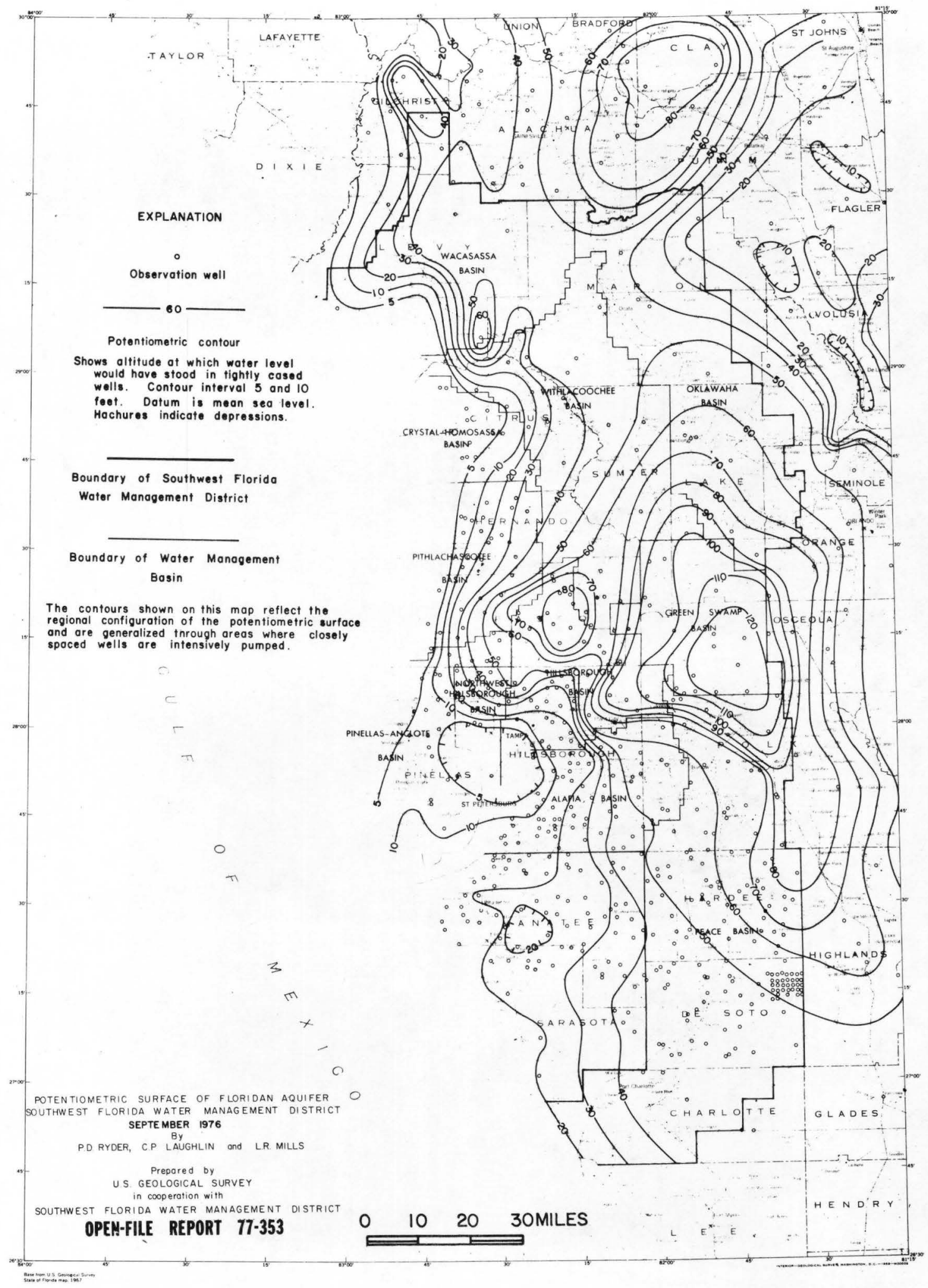

Figure 27. Potentiometric surface of the Floridan aquifer, September 1976. 


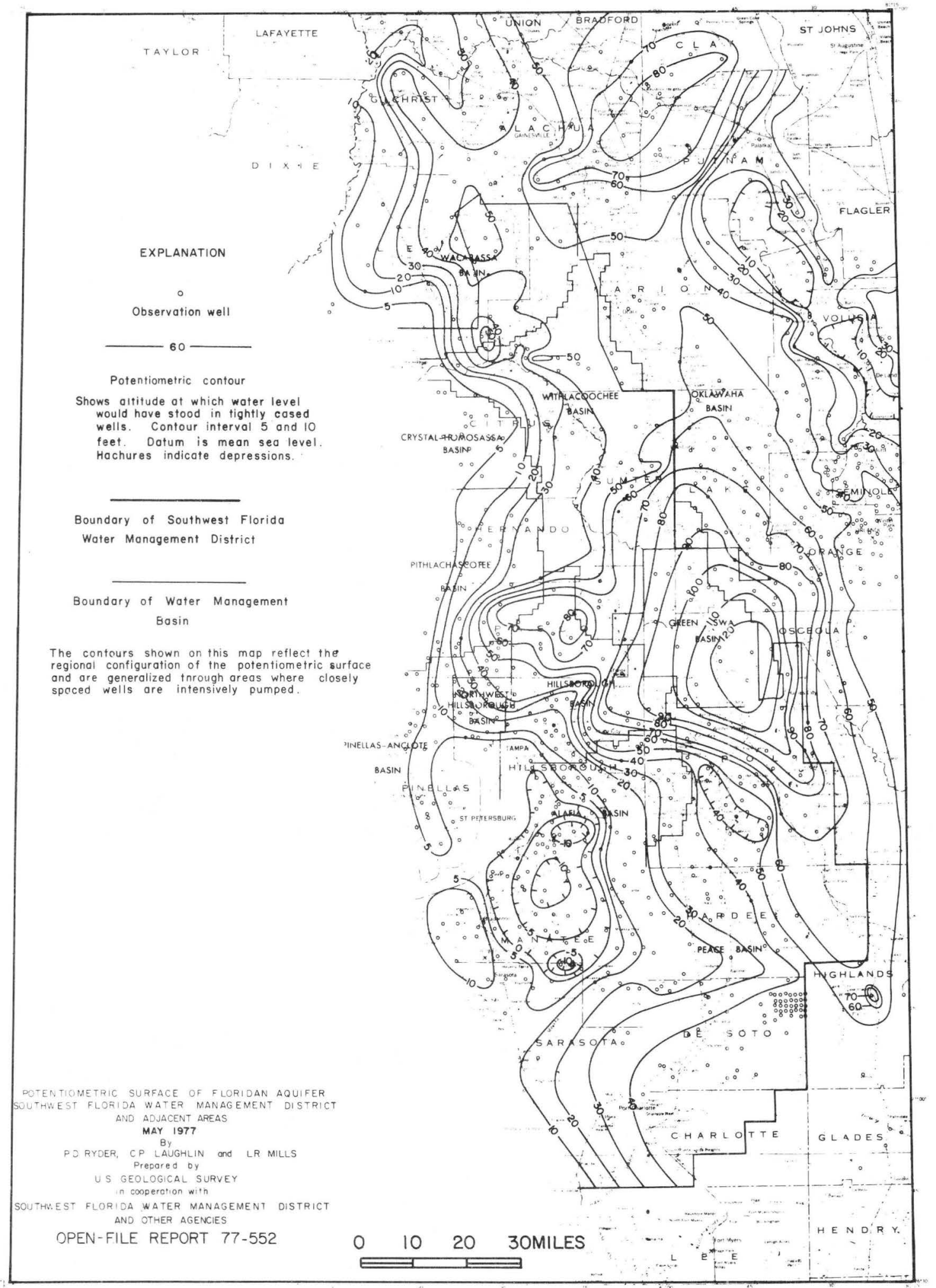

Figure 28. Potentiometric surface of the Floridan aquifer, May 1977. 


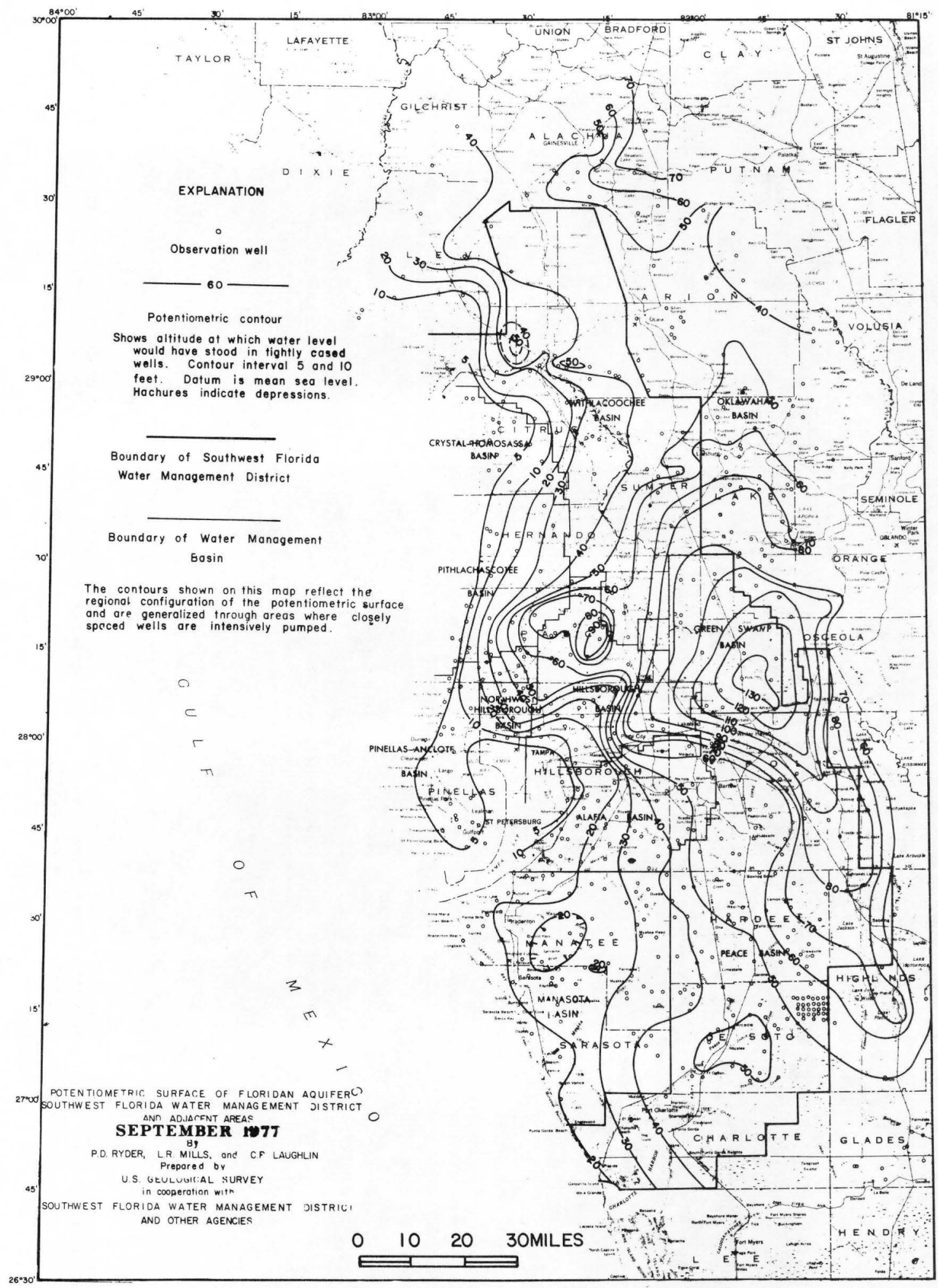

Figure 29. Potentiometric surface of the Floridan aquifer, September 1977. 


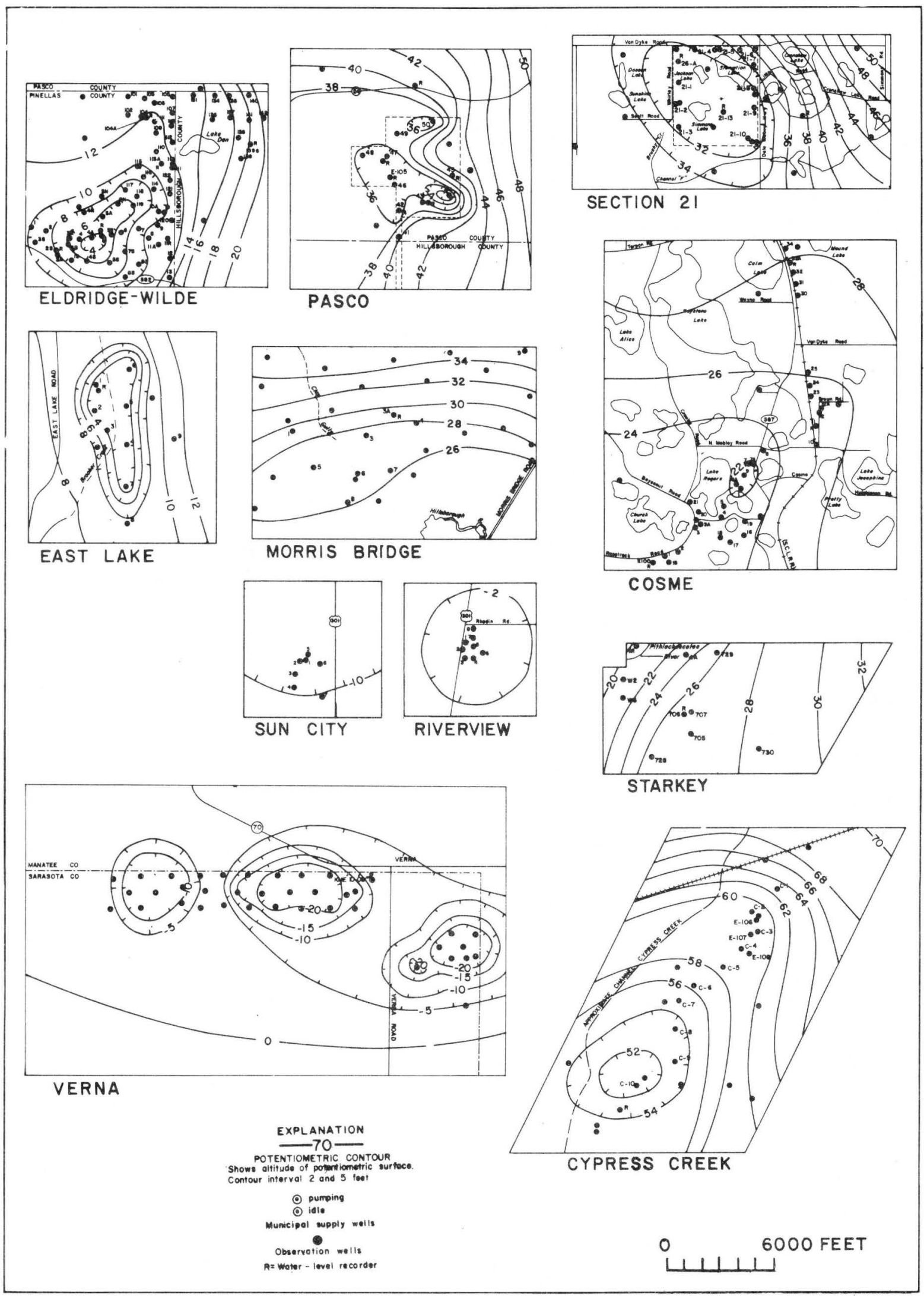

Figure 30. Potentiometric surface of the Floridan aquifer in selected well fields for May 1977. 


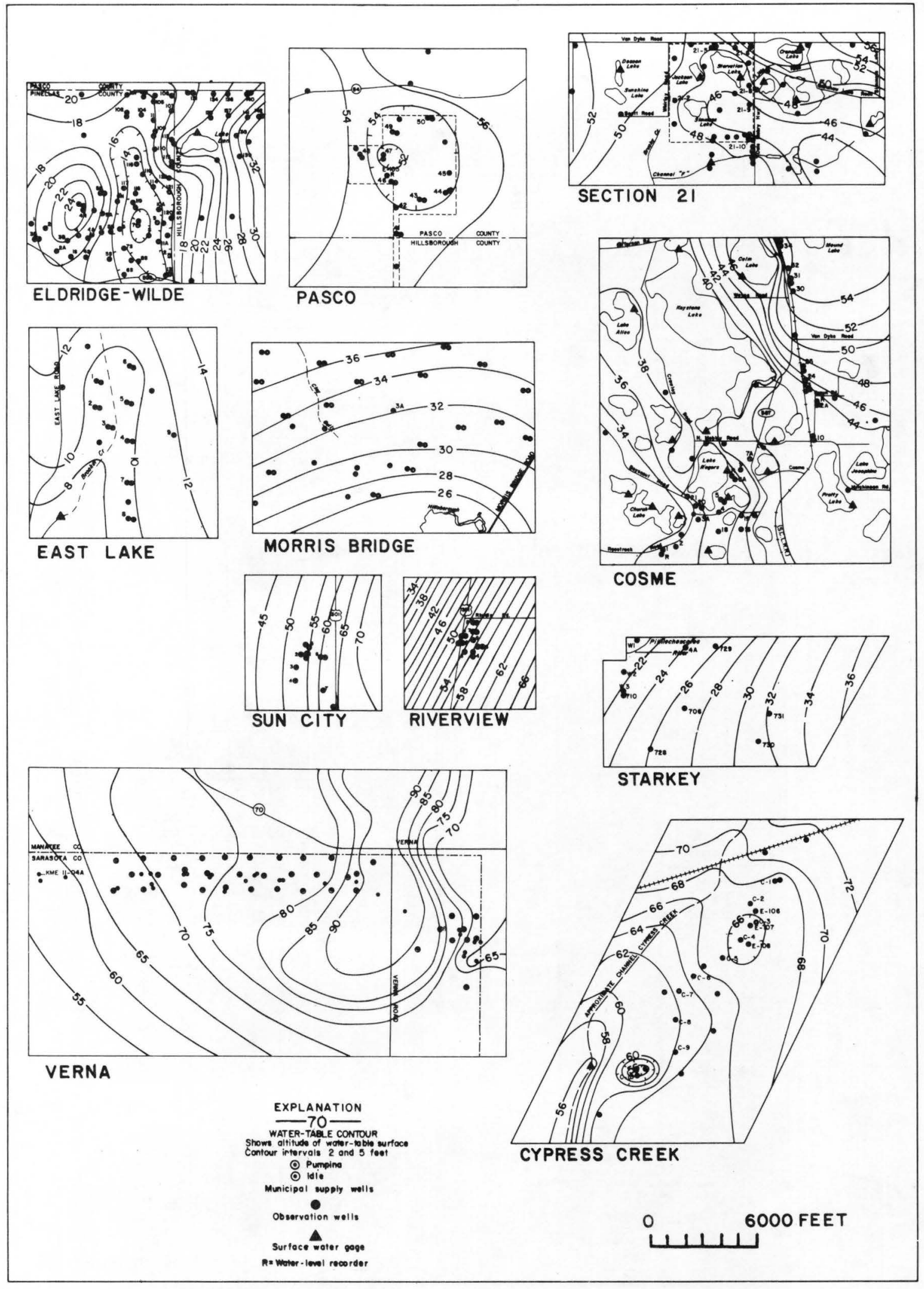

Figure 31. Water table in the surficial aquifer in selected well fields for May 1977. 


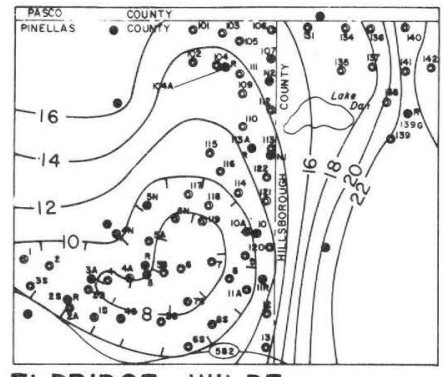

ELDRIDGE - WILDE

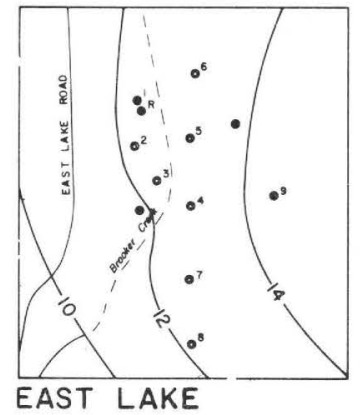

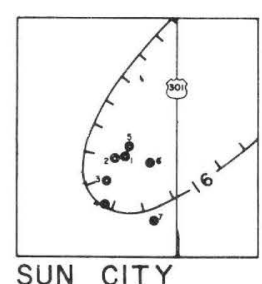

SUN CITY

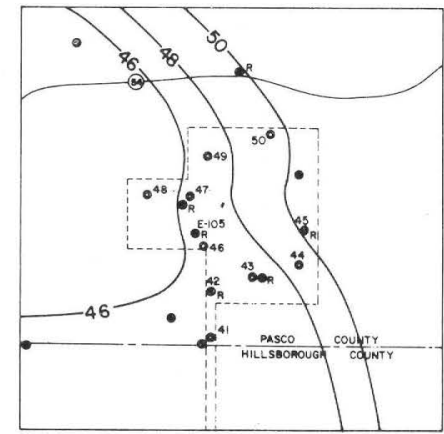

PASCO COUNTY

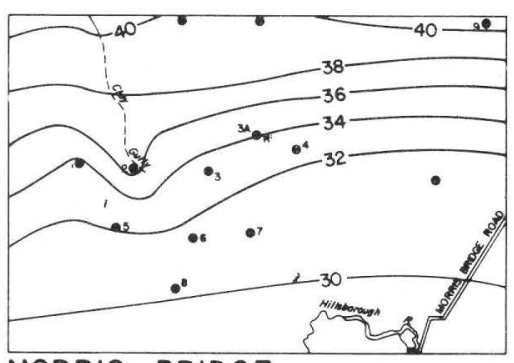

MORRIS BRIDGE

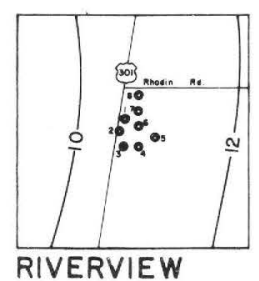

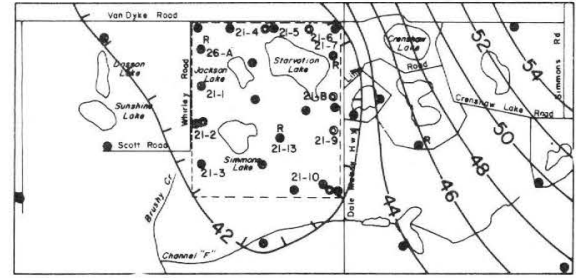

SECTION 21

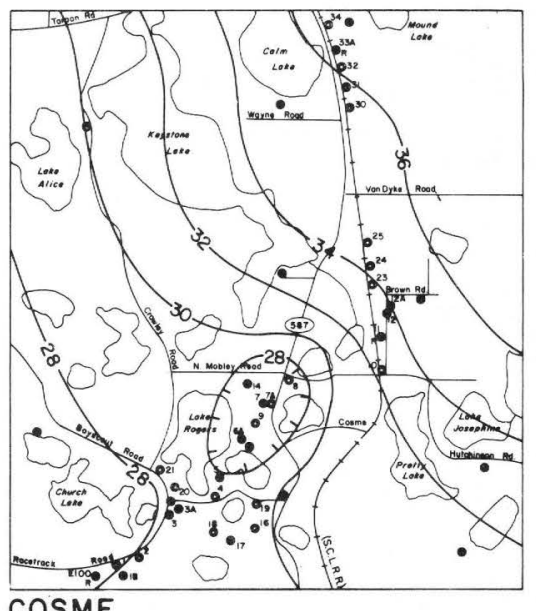

COSME

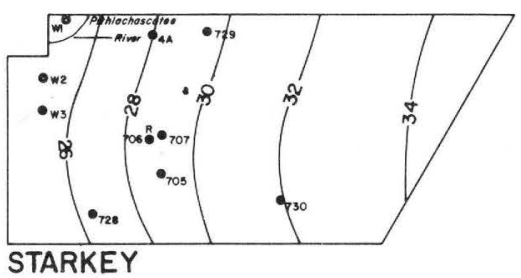

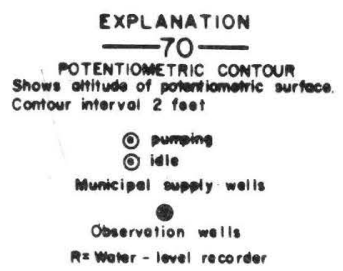

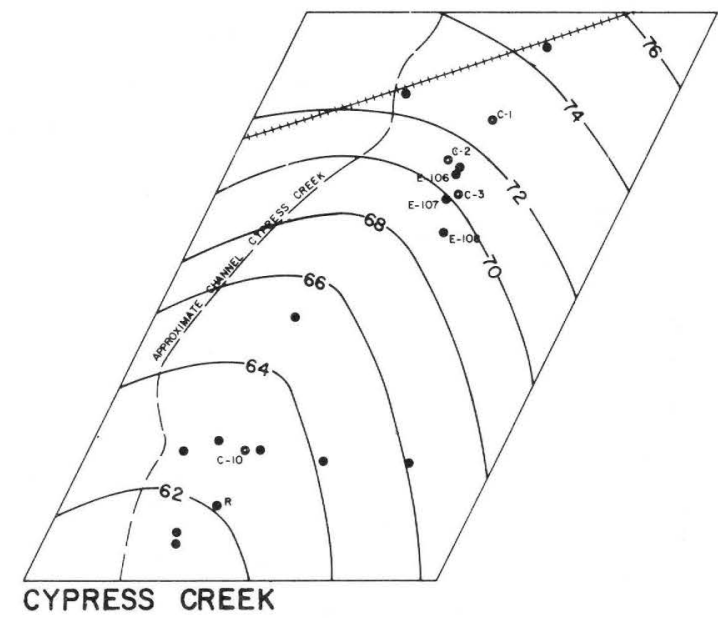

0

6000 FEET

Figure 32. Potentiometric surface of the Floridan aquifer in selected well fields for September 1977. 


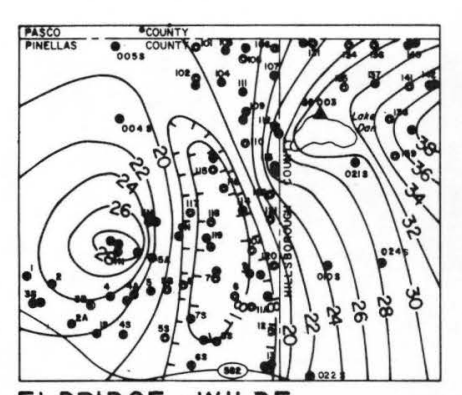

ELDRIDGE - WILDE

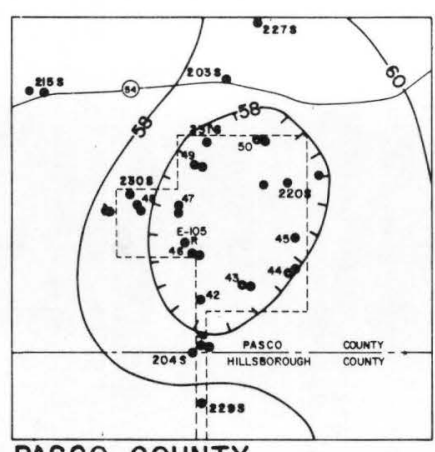

PASCO COUNTY

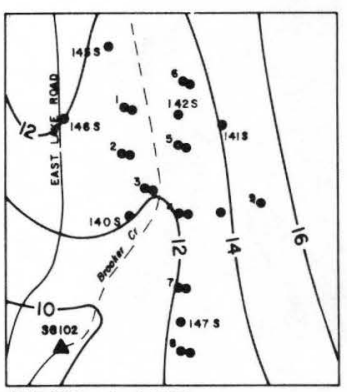

EAST LAKE
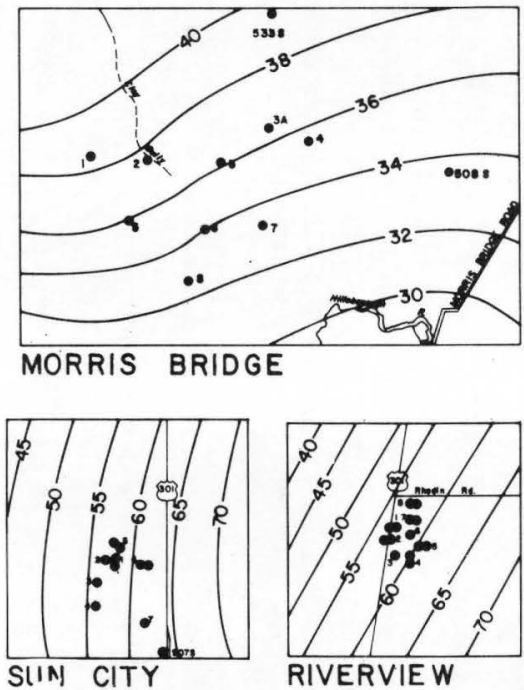

SIIN) CITY

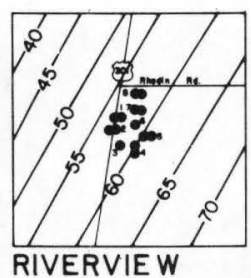

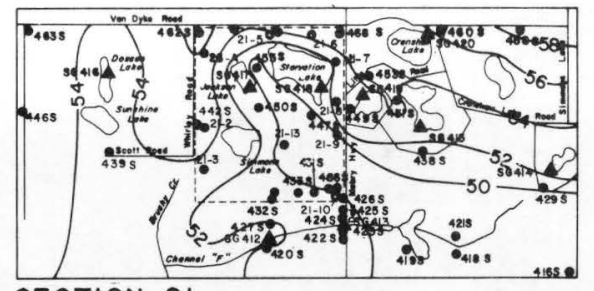

SECTION 21
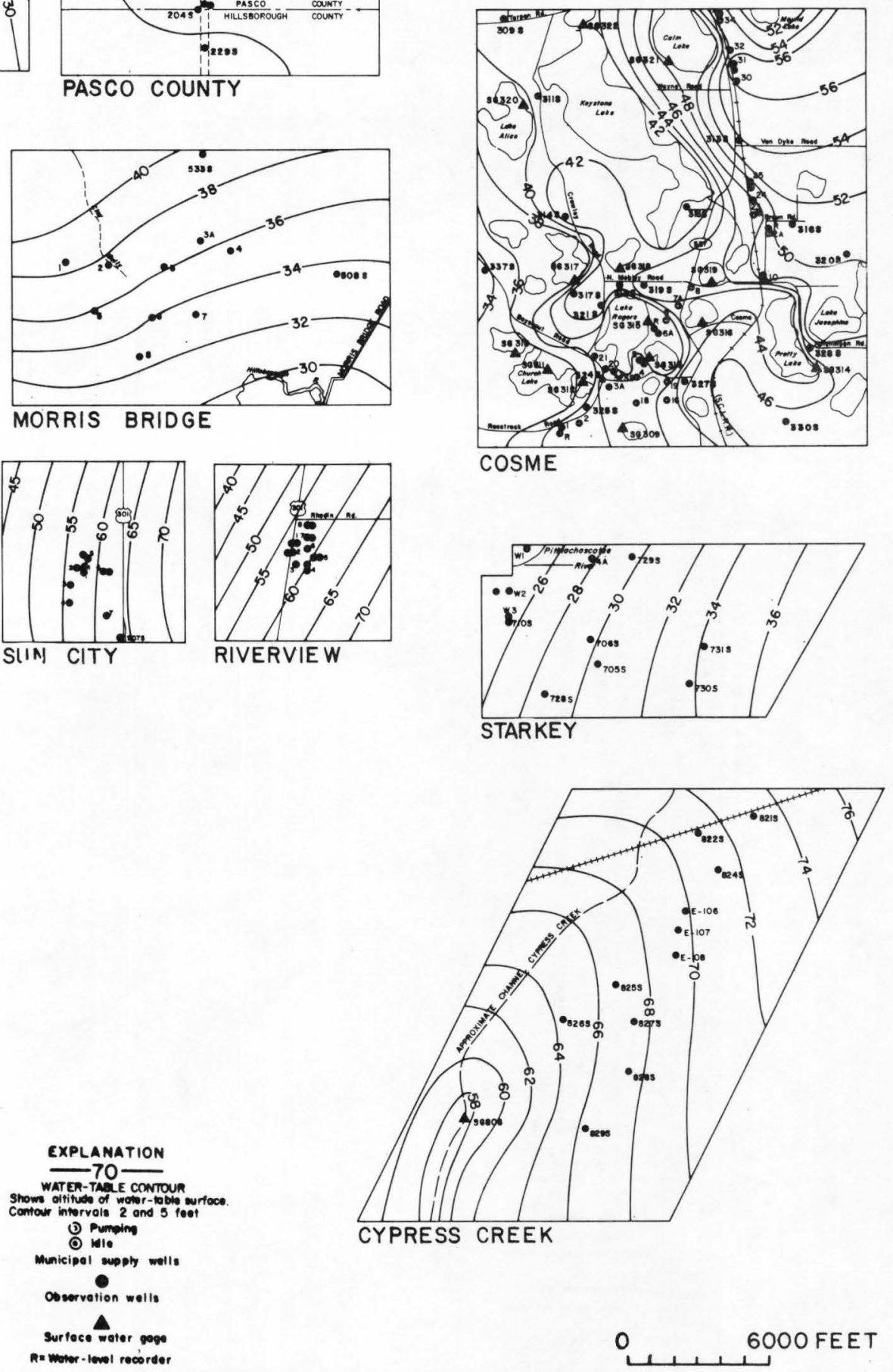

Figure 33. Water table in the surficial aquifer in selected well fields for September 1977. 
Long-term hydrographs for selected wells (fig. 34) are presented in figures 35 through 39. Brief discussions of water-level fluctuations in these wells follow.

In the northern part of southwest Florida, seasonal fluctuations in the potentiometric surface of the Floridan aquifer generally vary 1 to $3 \mathrm{ft}$. In the central part, the seasonal fluctuation is generally 5 to $10 \mathrm{ft}$, except in wells in the Peace River Basin where a range of 20 to $25 \mathrm{ft}$ in Polk County, and 30 to $40 \mathrm{ft}$ in Hardee County, is common. In the southern coastal areas, the seasonal fluctuation is generally 10 to $15 \mathrm{ft}$, except in Sarasota County where the water levels fluctuate 20 to $25 \mathrm{ft}$.

\section{Mulberry, Maddox, and Hollingsworth Wells}

The changes in potentiometric surface of the Floridan aquifer in the Peace River Basin are represented by hydrographs of the Mulberry, Maddox, and Hollingsworth wells (figs. 35 and 36). The Mulberry well showed a high of $59 \mathrm{ft}$ in October 1976. This was $7 \mathrm{ft}$ above the previous year. The seasonal low of $35 \mathrm{ft}$ occurred in May 1977 which was $4 \mathrm{ft}$ above the previous year. The water level in the Maddox we11 at the Polk-Hardee County line shows the same trend as the Mulberry well. The seasonal high level in the Hollingsworth well was $47 \mathrm{ft}$ in November 1976; $1 \mathrm{ft}$ below the previous year. The seasonal low of $33 \mathrm{ft}$ in May 1977 was virtually the same as the three previous years.

\section{Sarasota We11}

The water level in the Sarasota well 9 (fig. 36) showed a 4-ft rise from May 1976 to May 1977. The seasonal variations in water levels have increased in recent years and appear to correspond to variations in local ground-water withdrawals for irrigation.

\section{Verna Observation Wel1}

The Verna we11 1A (fig. 36) is in southern Manatee County, just north of the Verna well field (fig. 8) (Sarasota municipal water supply). Potentiometric levels increased $12 \mathrm{ft}$ from May to September 1977.

Counci1 We11

The Council well (fig. 37), in the agricultural part of southern Hillsborough County, defines conditions in the aquifer in an area of increased water use. The potentiometric surface high of $9 \mathrm{ft}$ in December 1976 was slightly lower than previous years. 
1. Múlberry Well at Mulberry

2. Maddox Well $\mathrm{nr}$ Bowling Green

3. Hollingsworth We1l nr Pine Level

4. Sarasota 9 Well $n r$ Sarasota

5. Verna Well nr Verna

6. Council Well $\mathrm{nr}$ Ruskin

7. Tampa 15 Well $\mathrm{nr}$ Dover

8. Cypress Creek Well 3 nr Darby

9. Pasco:Well $13 \mathrm{nr}$ Drexel

10. Hillsborough 13 Well nr Citrus Park

11. Eldridge-Wilde $11 \mathrm{nr}$ Tarpon Springs

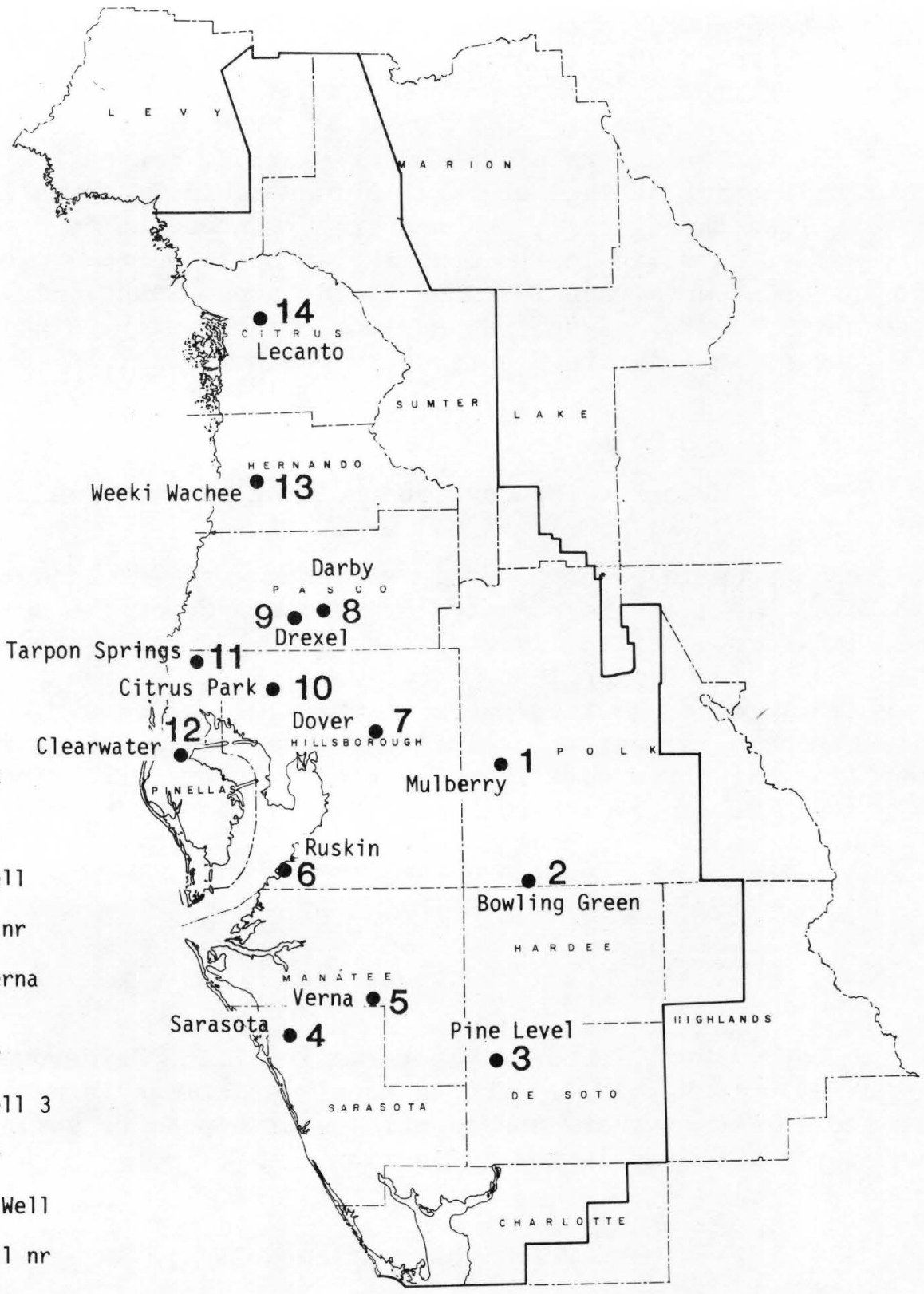

12. Pinellas 665 Well $\mathrm{nr}$ Clearwater

13. Weeki Wachee Well $\mathrm{nr}$ Weeki Wachee

14. North Lecanto Well $\mathrm{nr}$ Lecanto

\section{$\begin{array}{lllllll}10 & 0 & 10 & 20 & 30 & 40 & 50\end{array}$}

Figure 34. Location of Floridan aquifer wells for which hydrographs are presented in this report. 


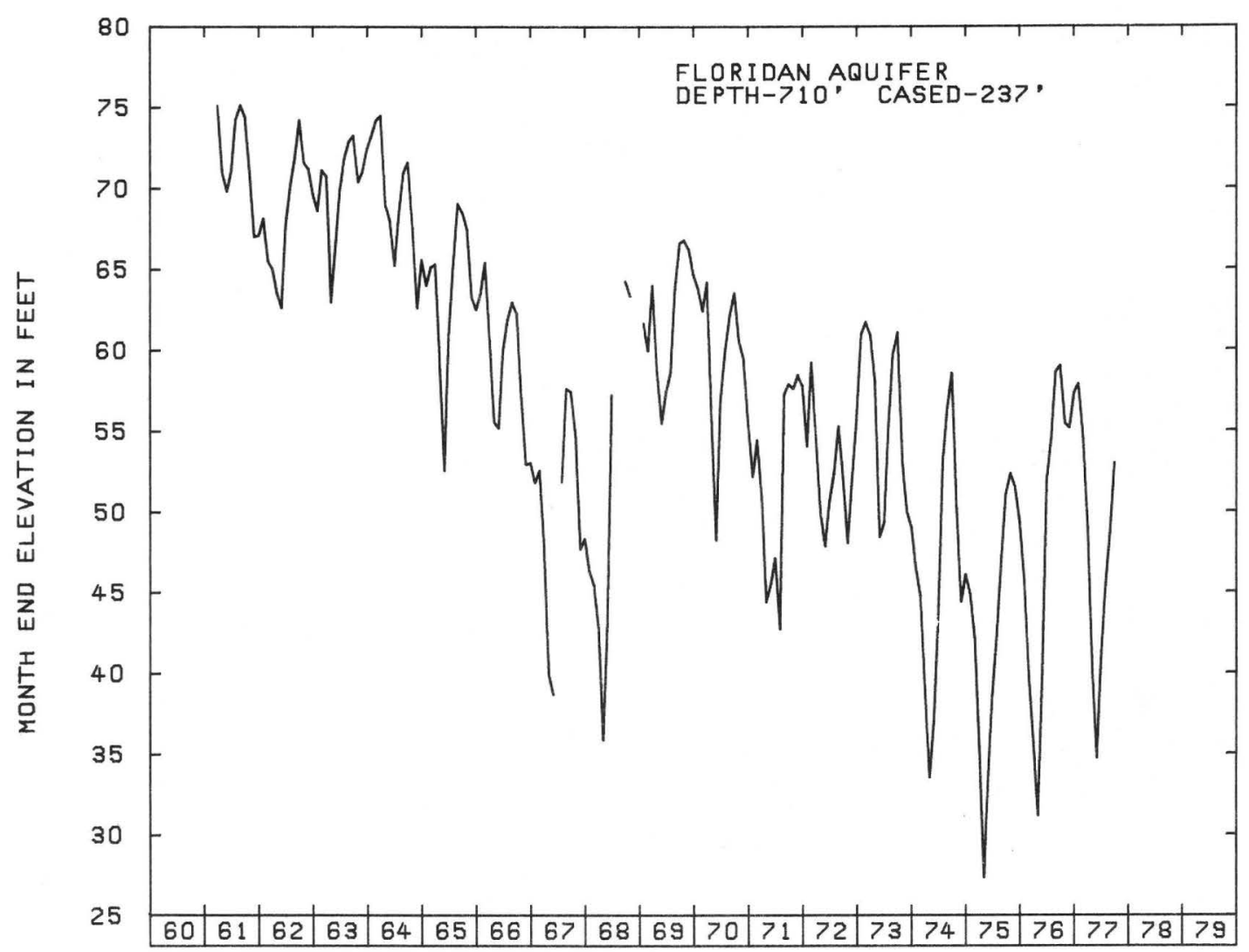

273849081511101

MADDOX WELL NR BOWLING GREEN

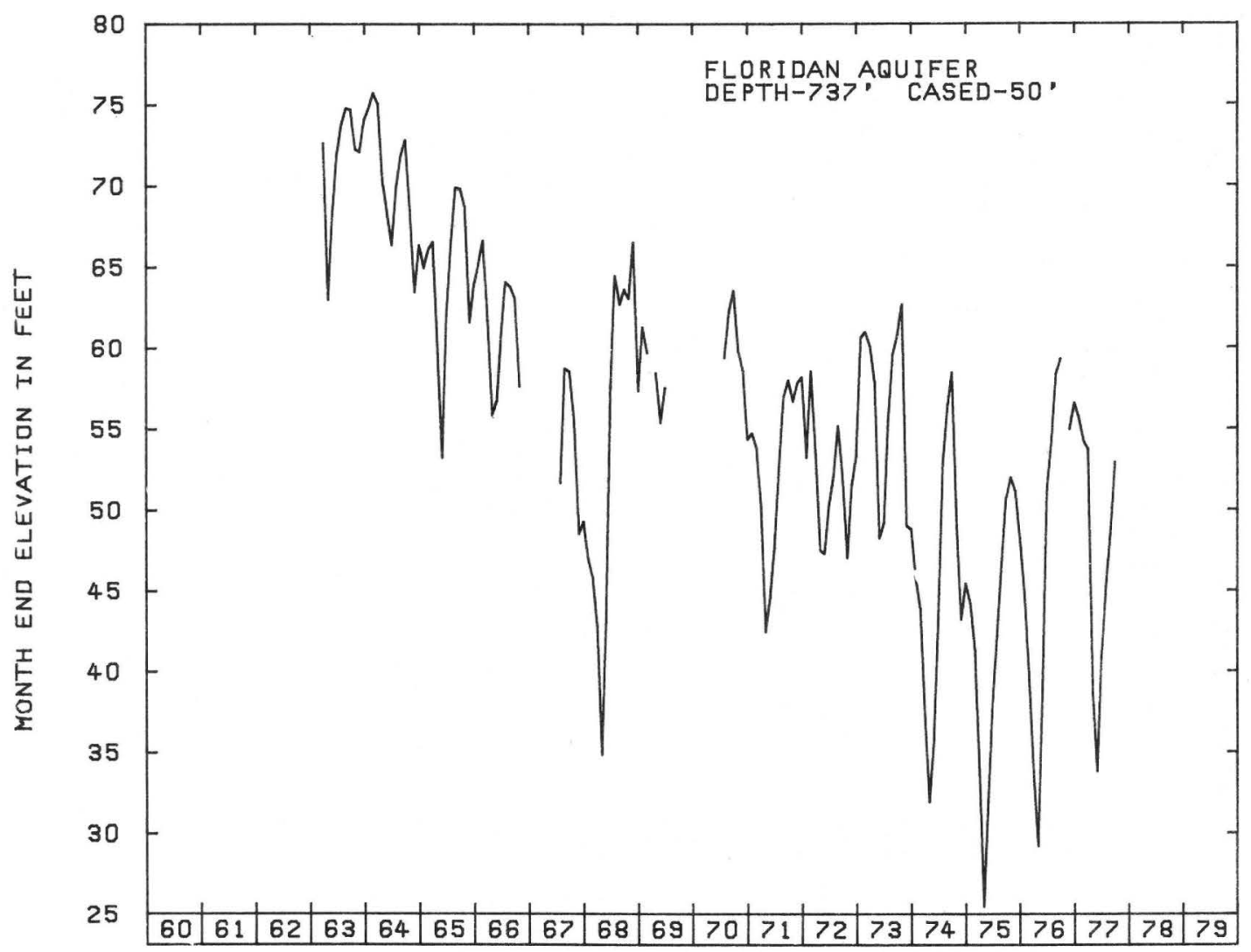

Figure 35. Hydrographs for Mulberry well at Mulberiy and Maddox well near Bowling Green. 

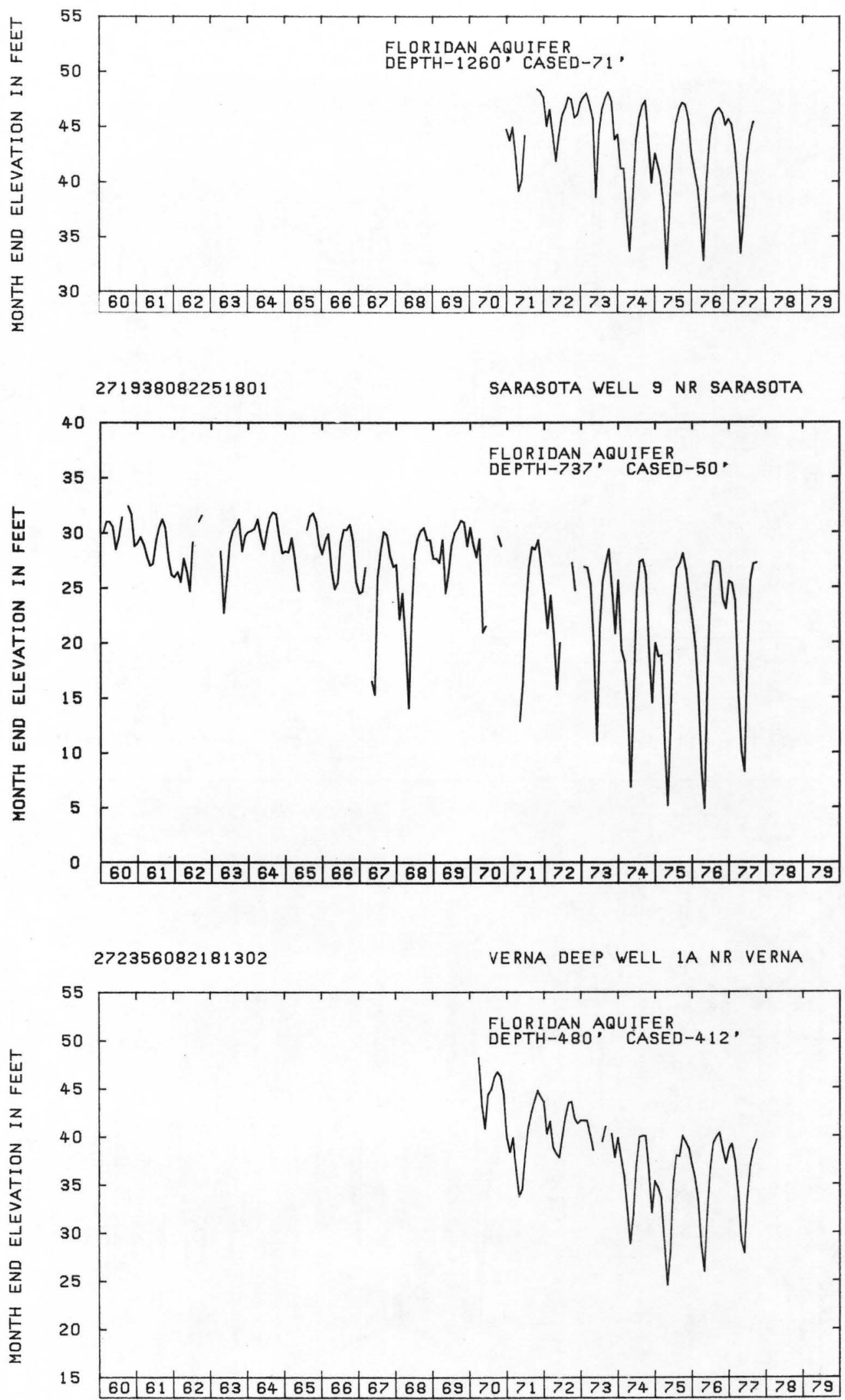

Figure 36. Hydrographs for Hollingsworth deep well near Pine level, Sarasota well 9 near Sarasota, and Verna deep well 1A near Verna. 
274455082252201

COUNCIL DEEP WELL NR RUSKIN

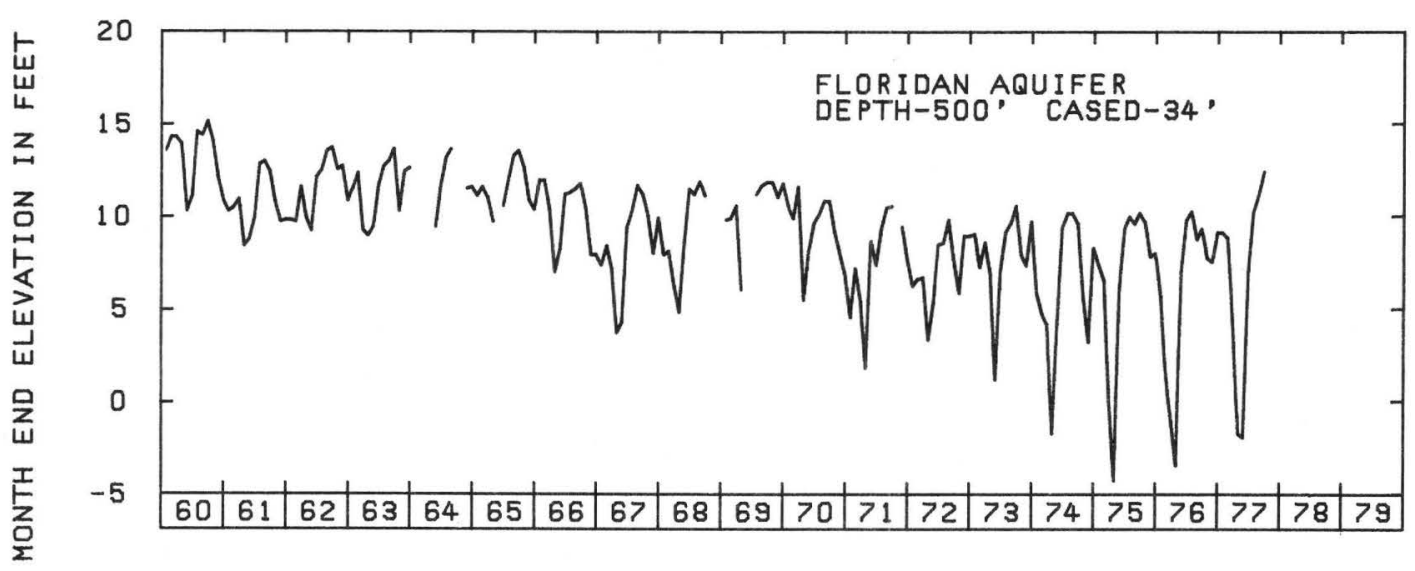

280145082132501

TAMPA WELL 15 NR DOVER

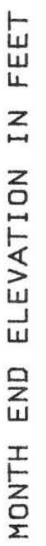
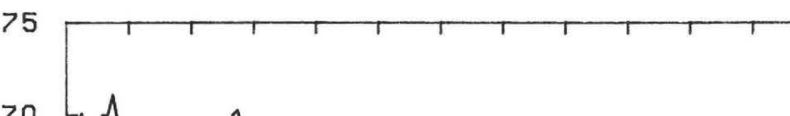

FLORIDAN AQUIFER

DEPTH-413' CASED-67'

70

M

$\eta_{M} V^{*}$

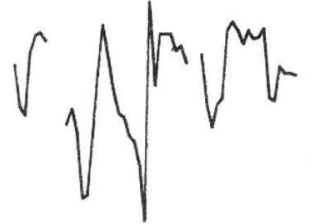

$N^{h} \sqrt{n}$

55

$-$

50

\begin{tabular}{|l|l|l|l|l|l|l|l|l|l|l|l|l|l|l|l|l|l|l|l|}
\hline 60 & 61 & 62 & 63 & 64 & 65 & 66 & 67 & 68 & 69 & 70 & 71 & 72 & 73 & 74 & 75 & 76 & 77 & 78 & 79 \\
\hline
\end{tabular}

280702082302801

HILLSBOROUGH DEEP WELL 13 NR CITRUS PARK

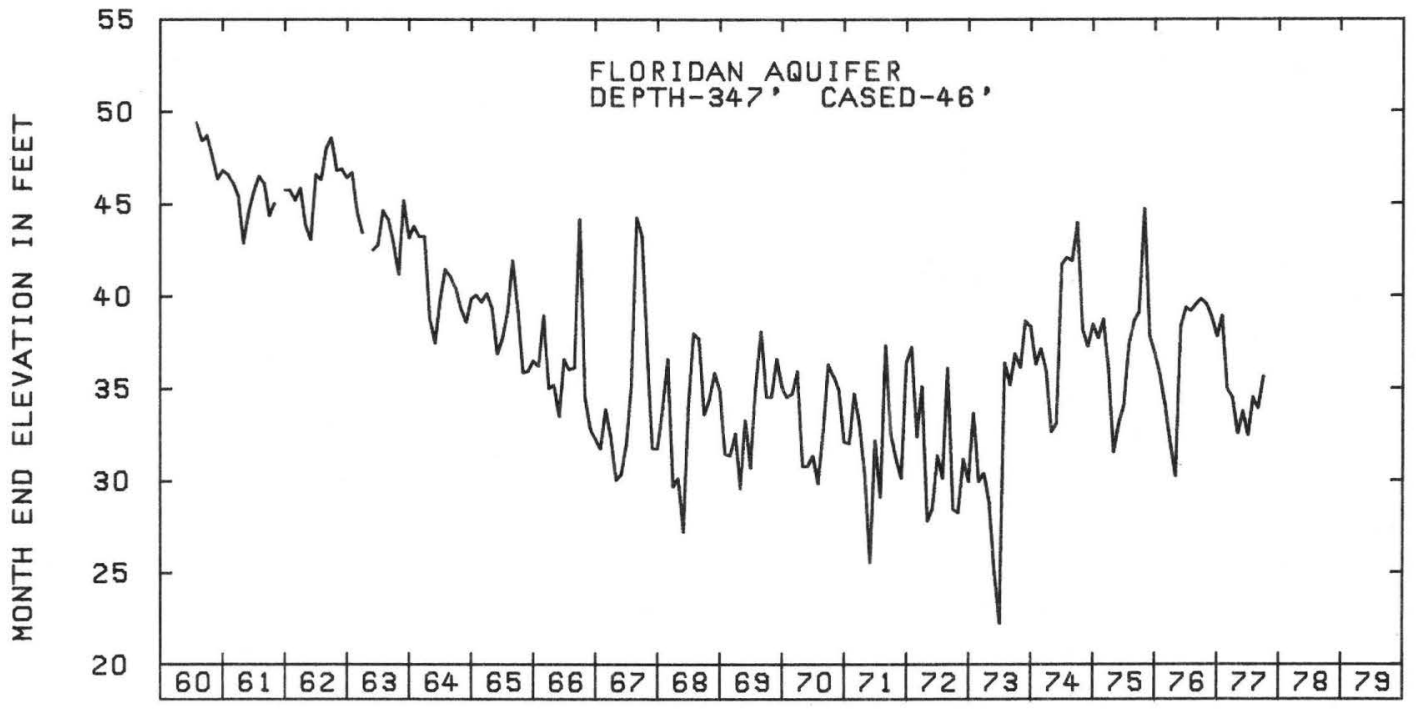

Figure 37. Hydrographs for Council deep well near Ruskin,

Tampa well 15 near Dover, and Hillsborough deep well 13 near

Citrus Park. 
Aquifer conditions in northeastern Hillsborough County, an area of relatively slight ground-water withdrawa1, is represented by Tampa we11 15 (fig. 37). The seasonal high of $66 \mathrm{ft}$ in September 1976 and low of $57 \mathrm{ft}$ in May 1977 each indicates little change in recent years.

\section{Hillsborough We11 13}

Water-level conditions in northwestern Hillsborough County, an area of several municipal well fields, is represented by Hillsborough we11 13 (fig. 37). The seasonal high of $40 \mathrm{ft}$ in October 1976 and seasonal low of $33 \mathrm{ft}$ in May 1977 represented conditions similar to the previous three years. The water levels for the past four years were about $6 \mathrm{ft}$ higher than during years 1968 to 1973.

Pasco We11 13

Pasco we11 13 (fig. 38) in the Cypress Creek basin in southern Pasco County shows a seasonal high of $74 \mathrm{ft}$ in July 1976 and a low of $71 \mathrm{ft}$ in June 1977.

Cypress Creek We11 3

Approximately $17 \mathrm{Mgal} / \mathrm{d}$ was pumped from the Cypress Creek well field during an aquifer test in 1977. The elevation of the potentiometric surface in Cypress Creek well 3 (fig. 38) was $61 \mathrm{ft}$ before pumping began in April 1977. The water level declined $52 \mathrm{ft}$ after approximately 3 months of pumping.

Eldridge-Wilde We11 11 and Pinellas We11 665

Conditions in western Pasco and northern Pinellas Counties are represented by E1dridge-Wilde we11 11 and Pinellas we11 665. The seasonal high of $13 \mathrm{ft}$ and low of $3 \mathrm{ft}$ at Eldridge-Wilde we11 11 (fig. 38) were essentially the same as in recent years, although a long-term decline of about one foot per year is indicated. Pinellas well 665 (fig. 39) showed a seasonal high of $11 \mathrm{ft}$ in the summer of 1976 which was a foot lower than the previous year. The seasonal low of $9 \mathrm{ft}$ in May was approximately the same level as the lows of the preceeding three years. 


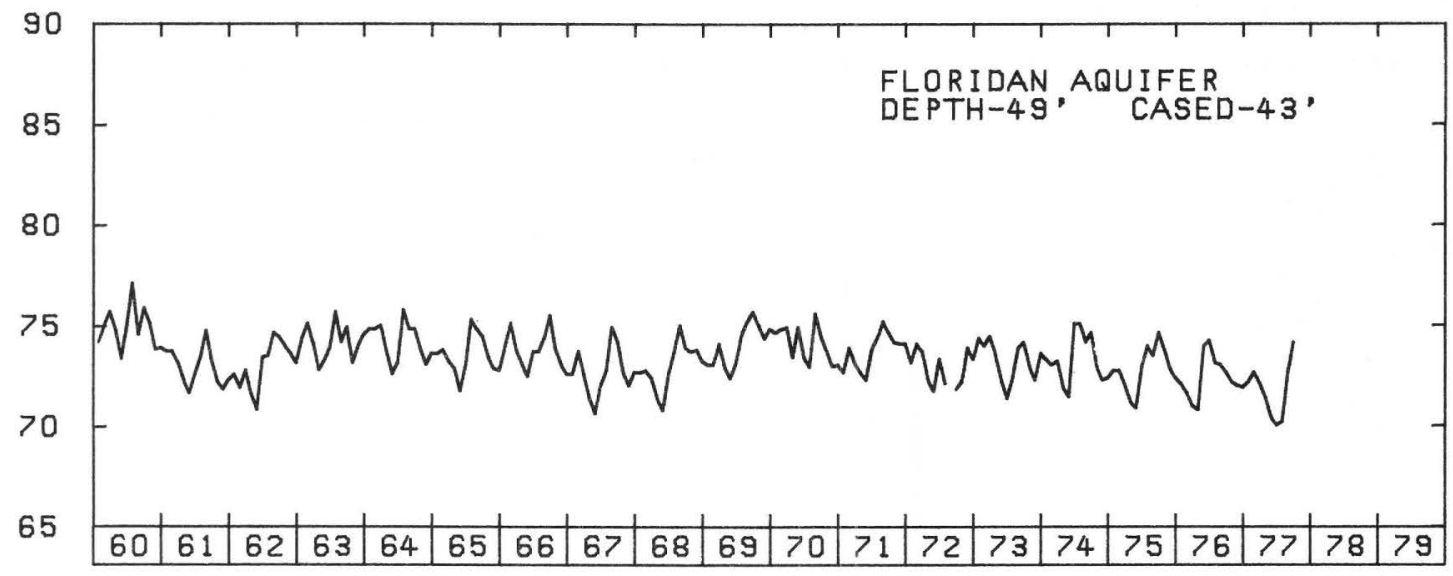

281622082241301

CYPRESS CREEK WELL 3 NR DARBY

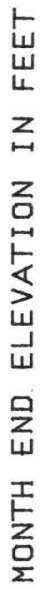

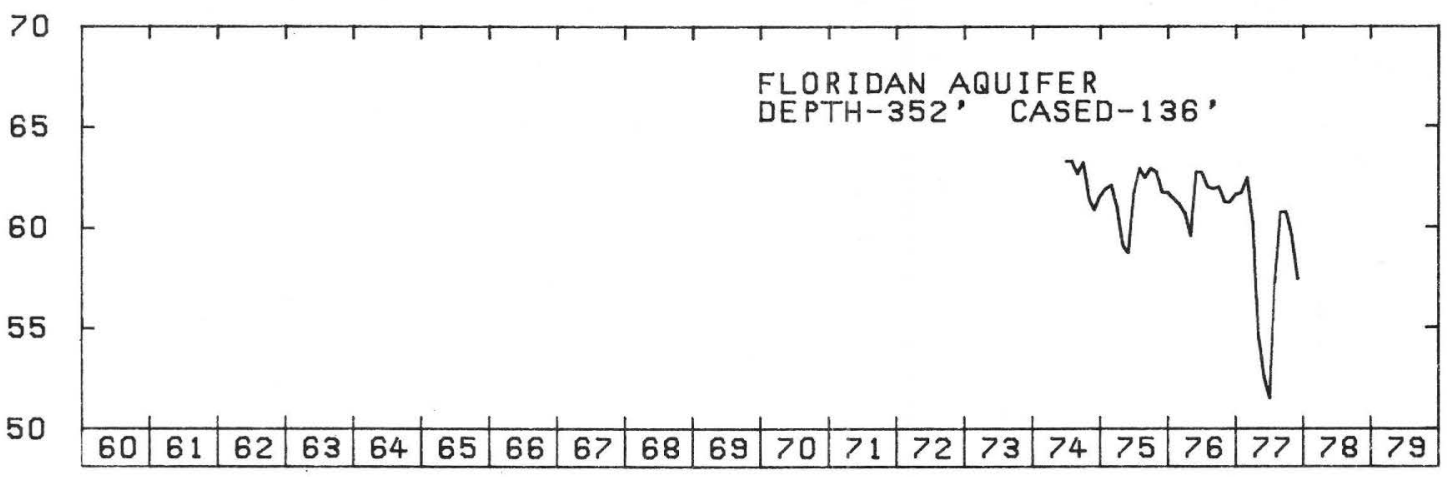

280904082390601

ELDRIDGE WILDE WELL 11 NR TARPON SPRINGS

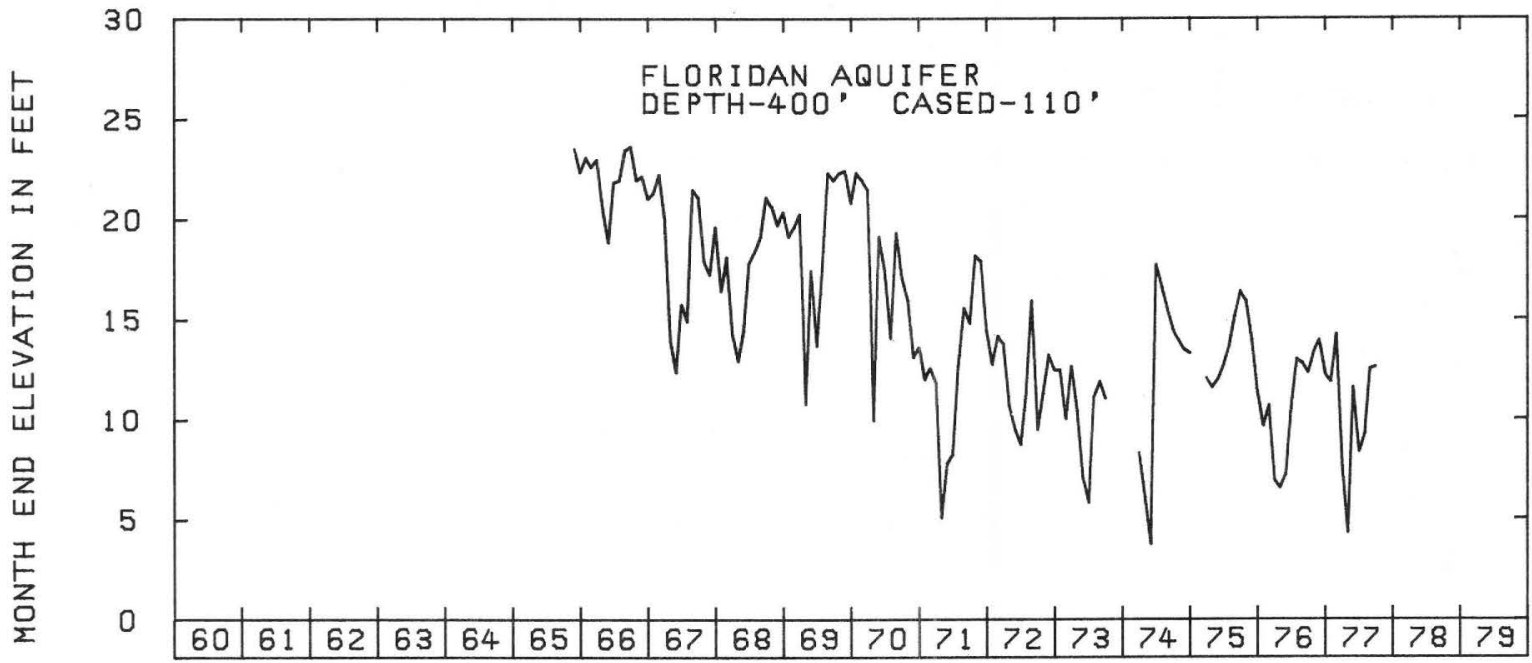

Figure 38. Hydrographs for Pasco well 13 near Drexel, Cypress Creek well 3 near Darby, and Eldridge-Wilde well 11 near Tarpon Springs. 


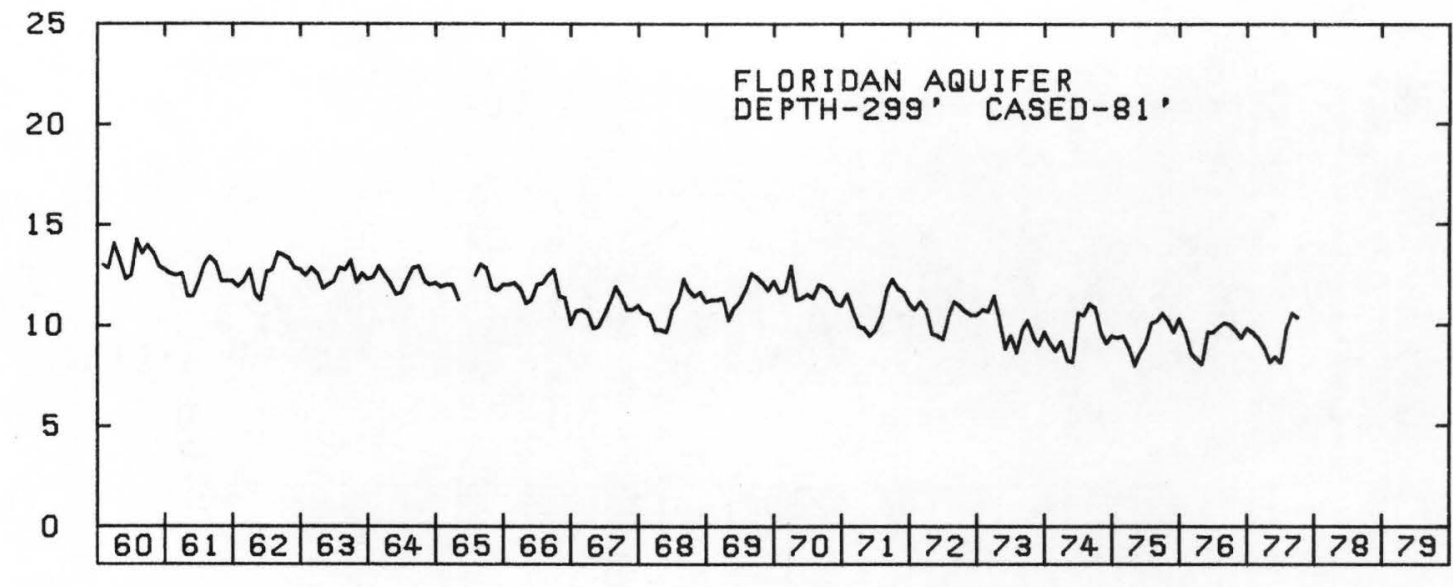

283201082315601

WEEKIWACHEE WELL NR WEEKIWACHEE

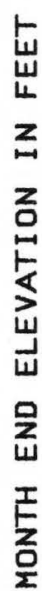

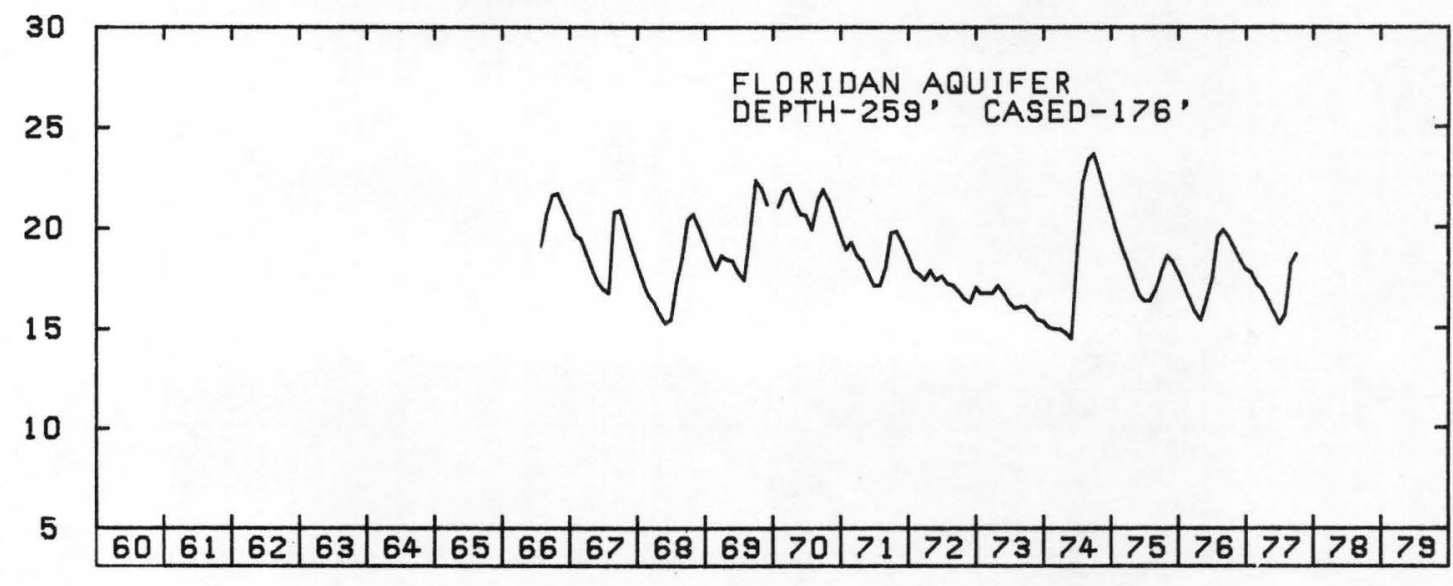

285414082284201

NORTH LECANTO DEEP WELL NR LECANTO

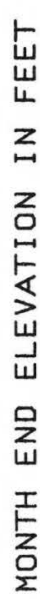

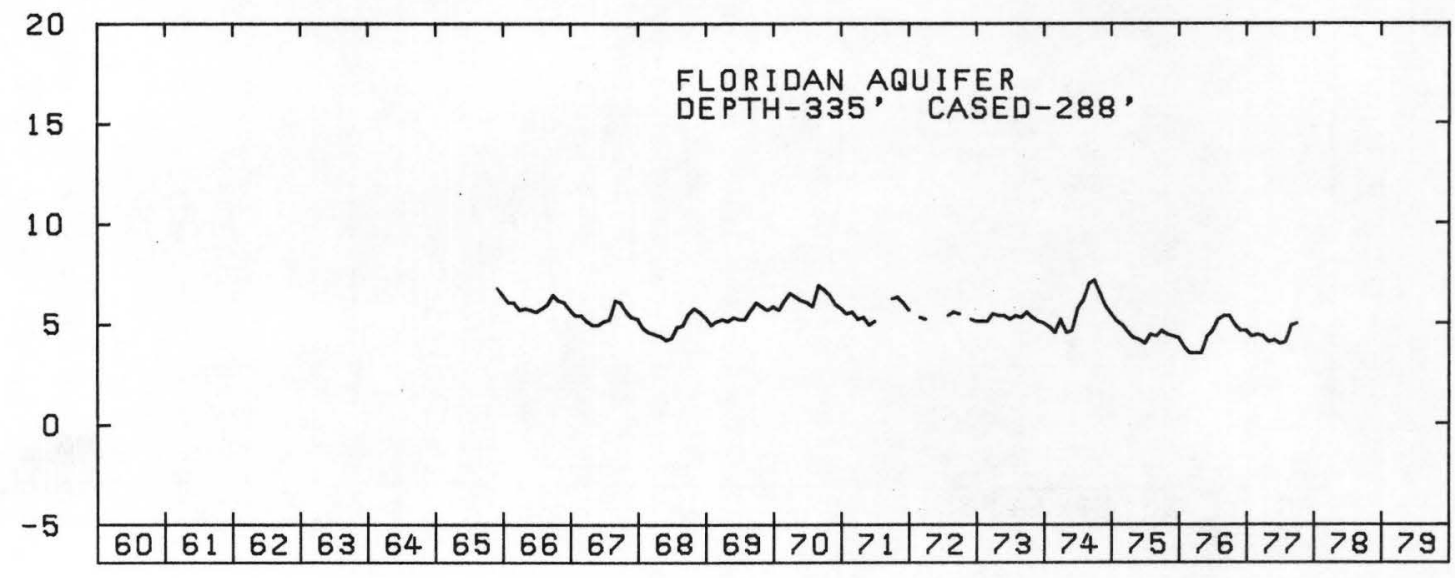

Figure 39. Hydrographs for Pinellas well 665 near Clearwater, Weeki Wachee well near Weeki Wachee, and North Lecanto deep well near Lecanto. 
Weeki Wachee We11 and North Lecanto We11

Conditions in the northern part of the coastal areas are represented by Weeki Wachee well and North Iecanto well. Records of the Weeki Wachee well (fig. 39) indicate the potentiometric surface in Hernando County fluctuates about $5 \mathrm{ft}$ each year with no long-range changes in water levels.

Records of water levels in the Lecanto well (fig. 39) indicate the potentiometric surface in Citrus County fluctuates about 1 to $2 \mathrm{ft}$ each year, with a long-term decline of about $0.10 \mathrm{ft}$ per year.

\section{Quality of Water}

The ground- and surface-water quality monitoring network was established to provide data necessary for local agencies to: (1) Define 1ocation and movement of the saltwater-freshwater interface; (2) locate areas where ground-water quality is deteriorating by sources other than sea water; (3) monitor movement of leachates from landfills and sprayeffluent irrigation sites; (4) predict long-term changes in the quality of ground water, streamflow and lakes; (5) make water-quality management decisions.

Water samples are analyzed for major inorganic constituents, trace metals, radiochemical constituents, organics, and biological characteristics. Samples of water are collected by the U.S. Geological Survey from about 220 surface-water sites (fig. 40) and from 700 wells (fig. 41). The chemical analyses are included in an annual report "Water Resources Data for Florida, 1976, Volume 3: Southwest Florida."

A major component of the ground-water quality monitoring network is the chloride monitoring network (fig. 42). Samples of water are collected at least once a year from 171 wells to monitor changes in the saltwaterfreshwater interface in the coastal parts of southwest Florida. Samples of water from 28 of these monitor wells in western Pasco County are co1lected and analyzed in January, March, May and September. Graphs of select chloride concentrations for wells in the monitoring network are presented in figures 43 to 45 .

New Port Richey We11

The chloride concentrations of samples from the New Port Richey well in Pasco County (fig. 43) about $2 \mathrm{mi}$ from the Gulf of Mexico, increased from about $5,000 \mathrm{mg} / \mathrm{L}$ (milligrams per liter) in 1972 to about 9,000 $\mathrm{mg} / \mathrm{L}$ in 1977. 


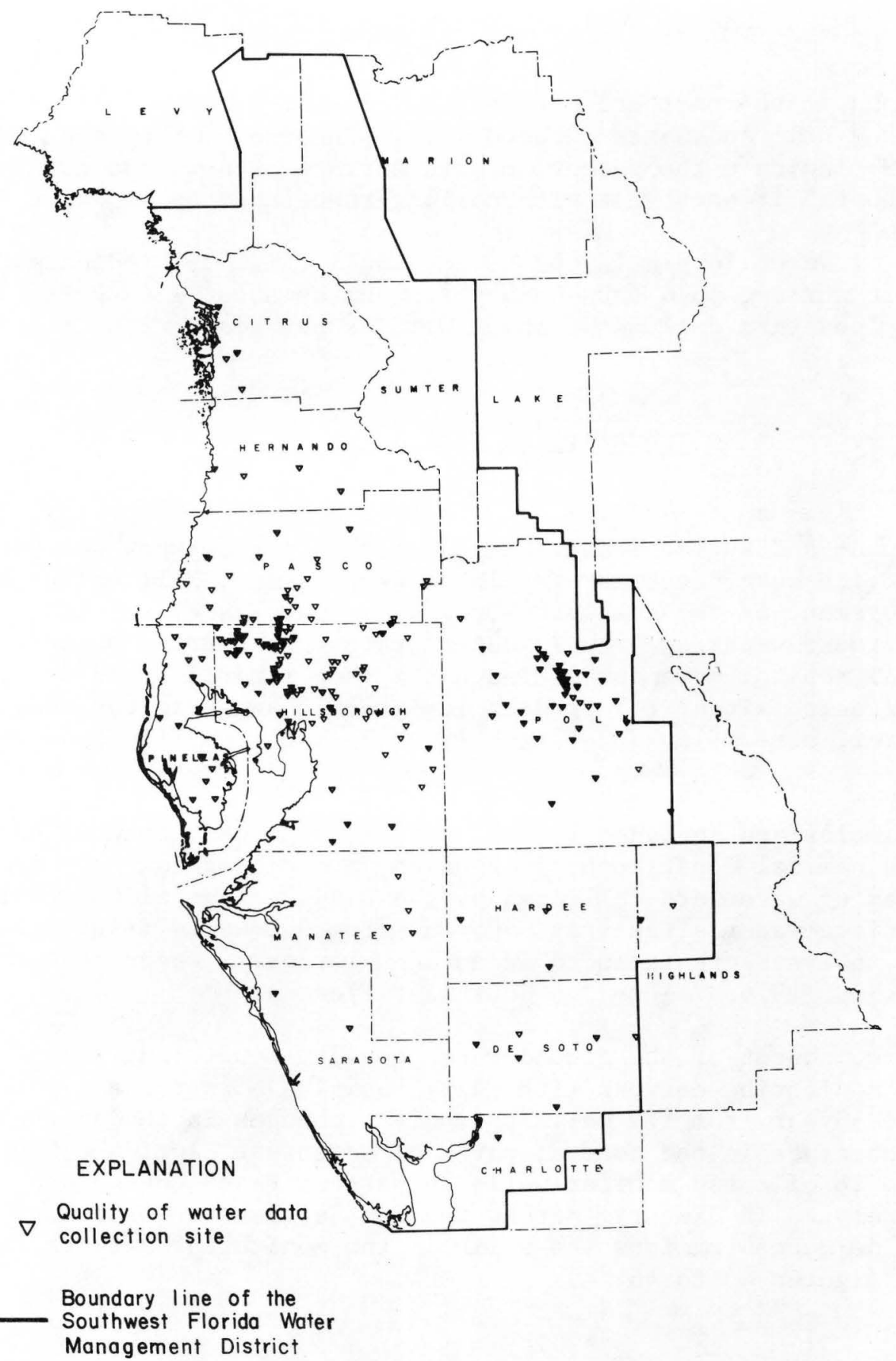

$\begin{array}{llllll}10 \quad 0 & 10 & 20 & 30 & 40 & 50\end{array}$

Figure 40. U.S. Geological Survey surface-water quality of water network in southwest Florida. 


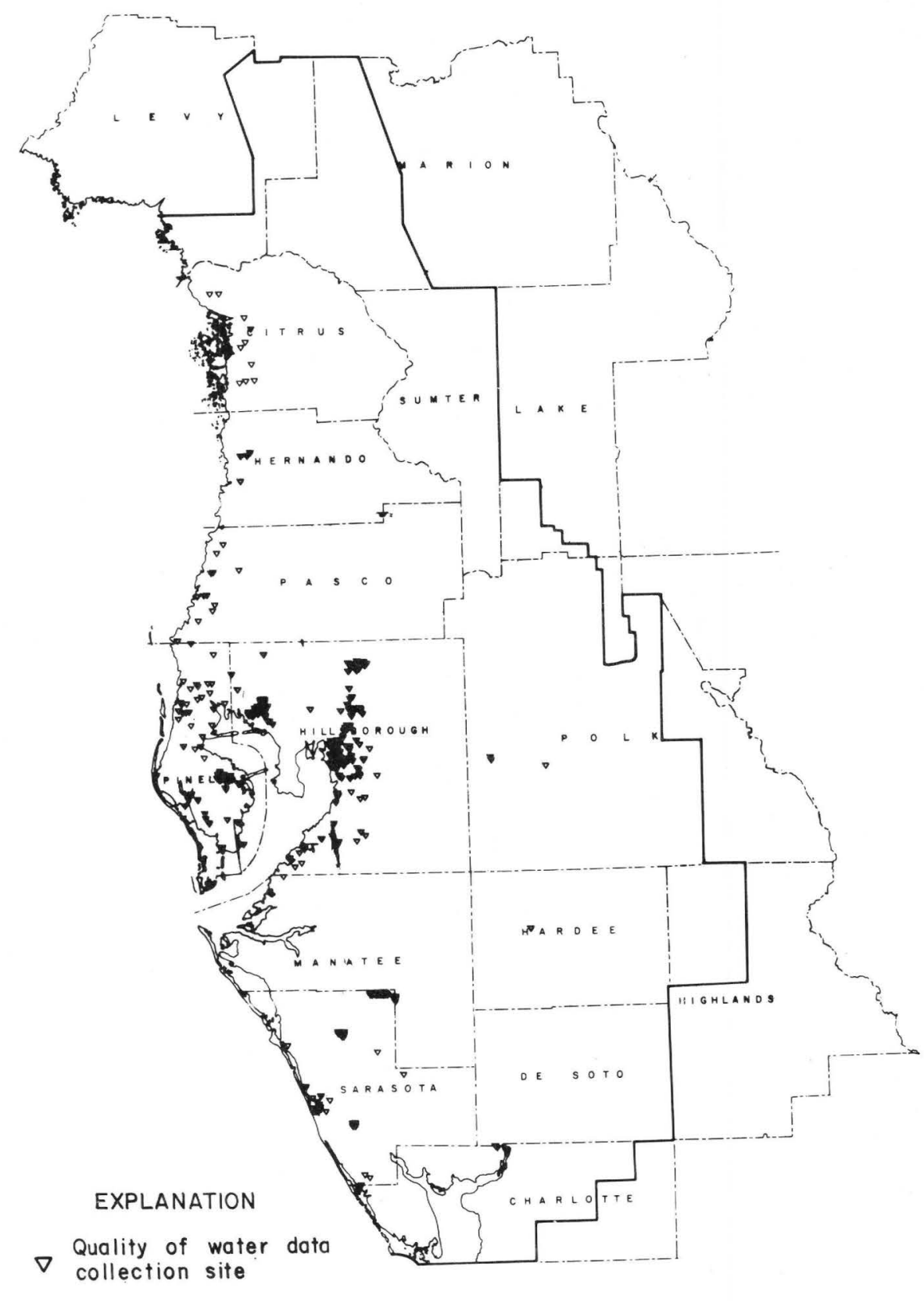

Boundary line of the

Southwest Florida Water

Management District

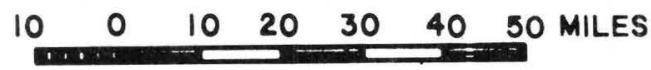

Figure 41. U.S. Geological Survey ground-water quality of water network in southwest Florida. 
EXPLANATION

- Chloride monitor well

- Well sites with hydrographs presented in this report

1. Homosassa Well No. $3 \mathrm{nr}$ Homosassa

2. Presbyterian Youth Camp Well nr Weeki Wachee

3. New Port Richey Deep Well at Richey Lakes

4. Coachman Road Well nr Clearwater

5. SWFWMD Well at $S-160$ nr Tampa

6. McMullen Campground Well nr Riverview

7. Claprod Well nr Ruskin

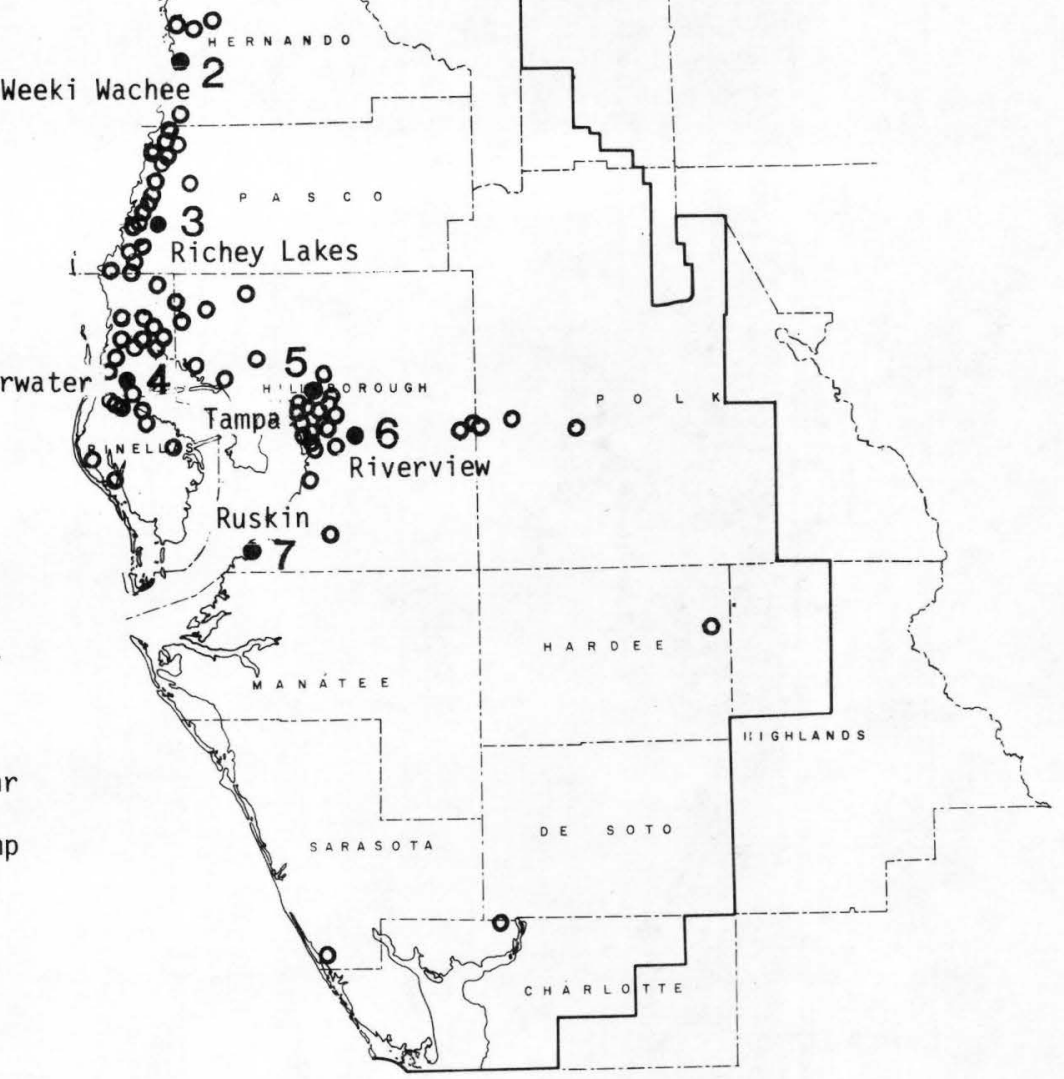

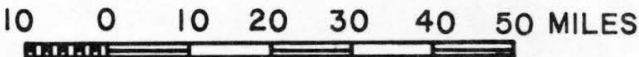

Figure 42. U.S. Geological Survey chloride monitor well network in southwest Florida. 

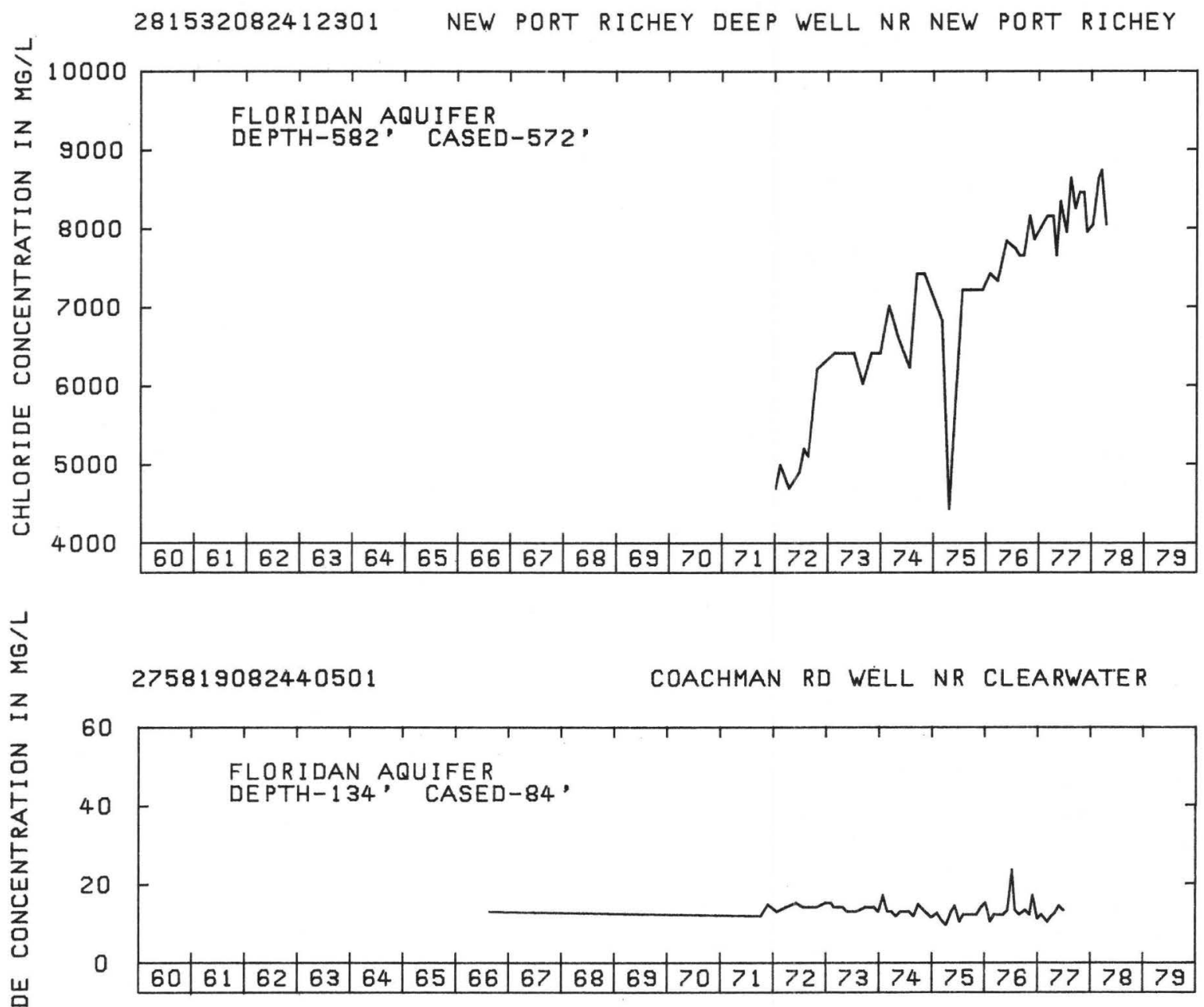

Figure 43. Chloride concentration for New Port Richey well near New Port Richey and Coachman well near Clearwater. 
The chloride data from the Coachman Road well (fig. 43) near Clearwater in Pinellas County showed no significant change in water quality since the well was first sampled in 1966.

\section{Presbyterian Youth Camp We11}

Chloride concentrations in water from the Presbyterian Youth Camp well (fig. 44) in Hernando County ranged from $420 \mathrm{mg} / \mathrm{L}$ in 1972 to 920 $\mathrm{mg} / \mathrm{L}$ in 1974. This variation represents extremes in the data which usually occurred during the dry season. The average chloride concentration is about $600 \mathrm{mg} / \mathrm{L}$ with an apparent increase of $20 \mathrm{mg} / \mathrm{L}$ per year since early 1974 .

Homosassa We11 No. 3

Samples from Homosassa well no. 3 (fig. 44) in Citrus County have shown an increase from an initial mean of about $100 \mathrm{mg} / \mathrm{L}$ in 1970 , to about $190 \mathrm{mg} / \mathrm{L}$ in 1977.

SWFWMD We11 at S-160

Chloride concentrations in water from the Southwest Florida Water Management District (SWFWMD) well at S-160 (fig. 45) at the Tampa By-Pass Cana1, about $3 \mathrm{mi}$ from Hillsborough Bay in Hillsborough County, showed a slight increase in chloride concentration from 50 to $85 \mathrm{mg} / \mathrm{L}$ from 1971 to 1977 .

\section{McMullen Campground}

The chloride concentrations of samples from the McMullen Campground well (fig. 45) in Hillsborough County showed only minor changes. The samples varied only $10 \mathrm{mg} / \mathrm{L}$ from 1969 to 1977.

\section{Claprod We11 near Ruskin}

The average chloride concentrations in water samples collected from the Claprod well (fig. 45) near Ruskin in Hillsborough County between 1952 and 1977 do not indicate a significant change in water quality. There has been an increase of 5 to $10 \mathrm{mg} / \mathrm{L}$ of chloride since the first sampling. 


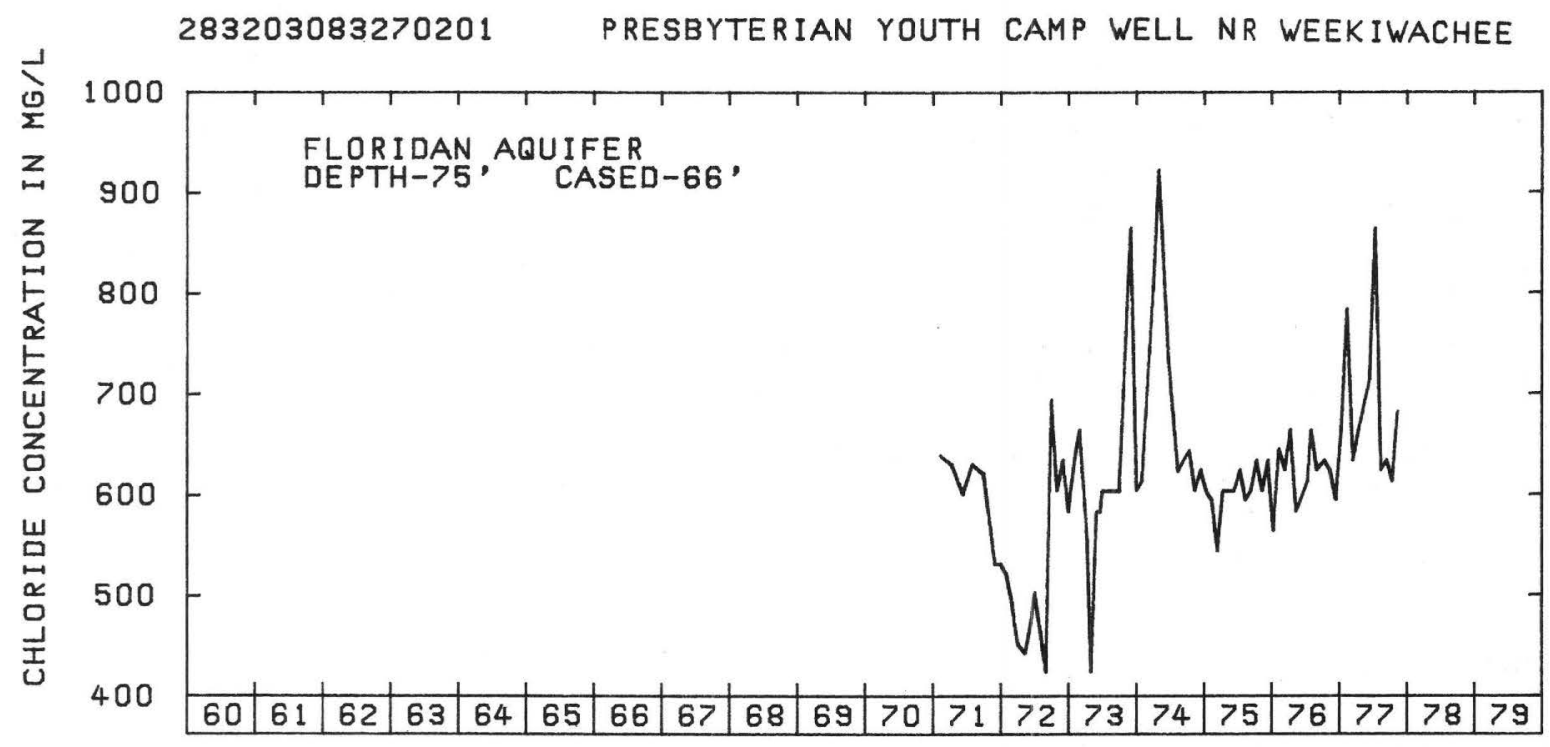

Jे

284551082345301

HOMOSASSA WELL 3 NR HOMOSASSA

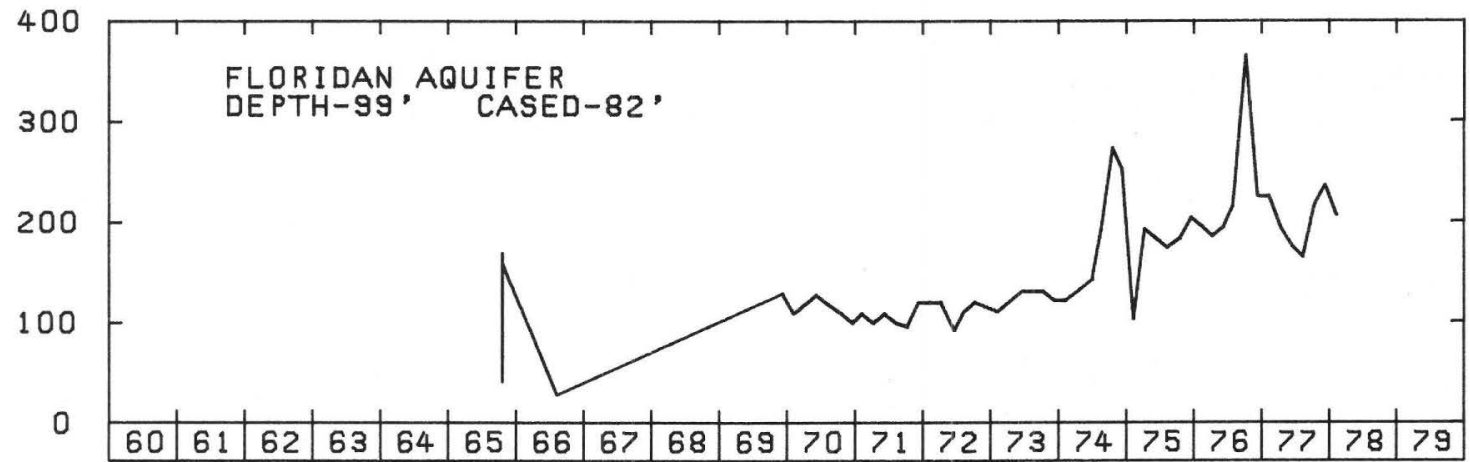

Figure 44. Chloride concentration for Presbyterian Youth Camp well near Weeki Wachee and Homosassa well 3 near Homosassa. 
275724082221001

SWFWMD WELL AT S-160 AT TAMPA

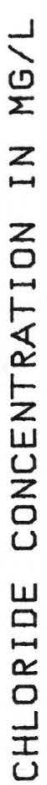

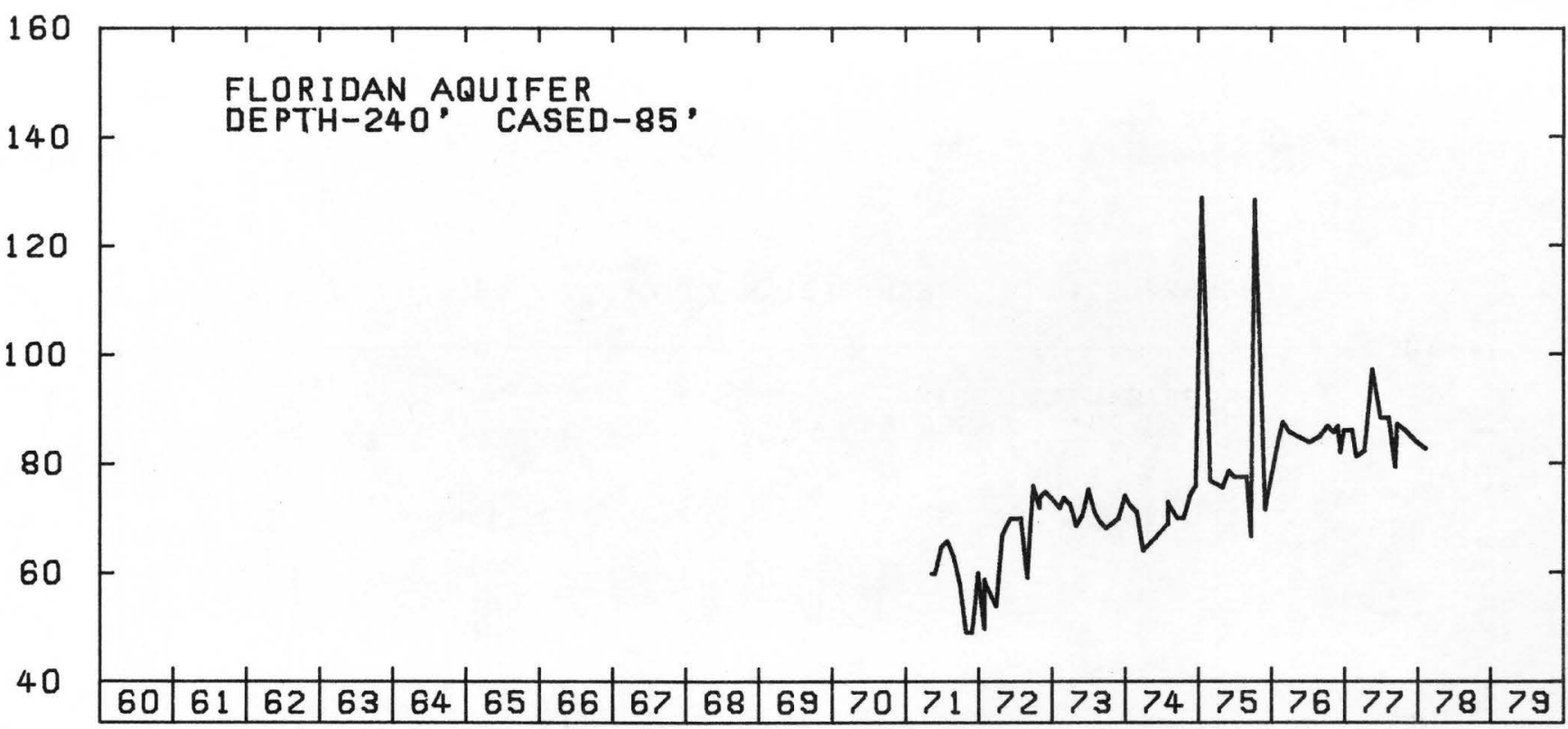

275210082171001

MC MULLEN CAMPGROUND S.E. NR RIVERVIEW

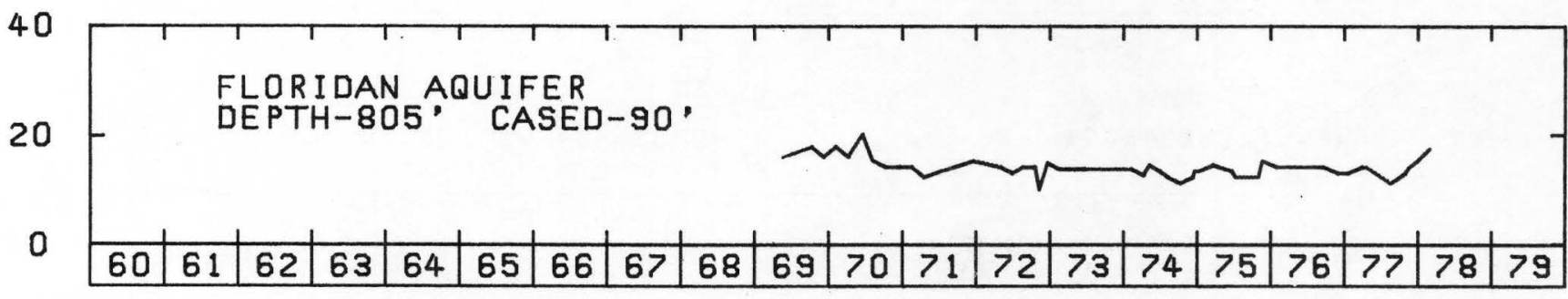

274114082303701

CLAPROD WELL NR RUSKIN

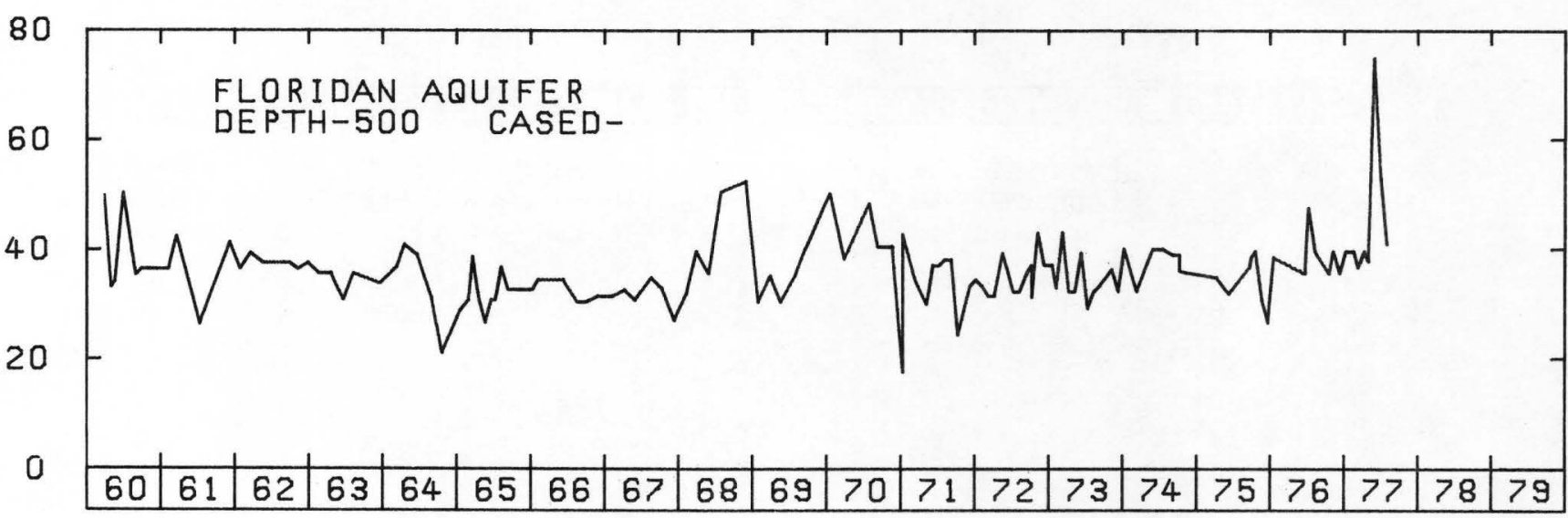

Figure 45. Chloride concentration for SWFWMD well S-160 at Tampa, McMullen Campground well near Riverview, and Claprod well near Ruskin. 